Danielle Fontes de Almeida

\title{
Avaliação do perfil de expressão gênica de linhagens celulares do tecido mamário com diferentes níveis de expressão do receptor HER-2 tratadas com ácido docosahexaenoico
}

Dissertação apresentada à Faculdade de Medicina da Universidade de São Paulo para obtenção do título de Mestre em Ciências

Programa de: Oncologia Orientador: Prof. Dr. Dan Linetzky Waitzberg

São Paulo 


\section{Danielle Fontes de Almeida}

\section{Avaliação do perfil de expressão gênica de linhagens celulares do tecido mamário com diferentes níveis de expressão do receptor HER-2 tratadas com ácido docosahexaenoico}

Dissertação apresentada à Faculdade de Medicina da Universidade de São Paulo para obtenção do título de Mestre em Ciências

Programa de: Oncologia Orientador: Prof. Dr. Dan Linetzky Waitzberg

São Paulo 
Dados Internacionais de Catalogação na Publicação (CIP)

Preparada pela Biblioteca da

Faculdade de Medicina da Universidade de São Paulo

Creprodução autorizada pelo autor

Almeida, Danielle Fontes de

Avaliação do perfil de expressão gênica de linhagens celulares do tecido mamário com diferentes níveis de expressão do receptor HER-2 tratadas com ácido docosahexaenoico / Danielle Fontes de Almeida. -- São Paulo, 2013.

Dissertação(mestrado)--Faculdade de Medicina da Universidade de São Paulo.

Programa de Oncologia.

Orientador: Dan Linetzky Waitzberg.

Descritores: 1.Neoplasias da mama 2.Linhagem celular 3.Ácidos graxos ômega-3 4.Ácidos docohexaenoicos 5.Expressão gênica 6.Nutrigenômica 7.Receptor HER-2

USP/FM/DBD-110/13 
À pessoa mais importante durante toda essa trajetória,

Rita de Cássia Borges de Castro.

Se não fosse por você tudo teria sido muito mais difícil. Amigos são anjos enviados para cuidarem de nós. 
À minha família:

Meus pais e meus irmãos que sempre me apoiaram;

Minhas amigas da vida inteira, pela força e carinho de sempre;

Meu namorado, Marcelo, por todo o amor e dedicação.

A importância que vocês têm na minha vida

supera os limites da escrita. 
Ao meu grande mestre e orientador Prof. Dan L. Waitzberg, por toda a orientação nesses anos, por todo apoio na pesquisa científica e nas escolhas da minha vida.

À querida tutora Rose, Rosimeire Aparecida Roela, por todo carinho, paciência, ensinamentos científicos e pessoais.

À pequena Tuty, Tatiane Furuya, que me ajudou muito com seus detalhes, tanto nos experimentos quanto na parte teórica.

Aos meus amigos queridos, Paulo Roberto Del Valle, Simone Fernandes, Ruan Mendrano e Thiago Salles, pelas conversas moleculares e por toda a companhia de sempre.

À Aline de Conti, pesquisadora e mulher que tanto admiro meus agradecimentos em especial pela fase da escrita do artigo científico.

À minha amiga Karina Al Assal, nutricionista que me transborda de orgulho.

À Dra. Ângela Flávia Logullo Waitzberg por ter me recebido em sua casa com tanto carinho por todos esses anos, pelas conversas científicas e pela elaboração do artigo científico.

Aos colegas do laboratório Metanutri por todos esses anos de discussão cientifica. Em especial à Priscila Garla, por todas nossas conversas e pela nossa amizade.

Ao laboratório de oncologia experimental, LIM 24, grupo mama, por toda dedicação e companheirismo.

Ao laboratório do Prof. Roger Chammas por toda ajuda durante esse percurso.

À todos os funcionários a FMUSP que me ajudaram por todos esse anos.

Enfim, a todos que me ajudaram de alguma maneira nesse projeto e na minha vida! 
O presente trabalho foi realizado no Laboratório de Nutrição e Cirurgia Metabólica do Aparelho Digestivo (LIM35) do Departamento de Gastroenterologia em conjunto com o Laboratório de Oncologia Experimental (LIM 24) do Departamento de Radiologia,ambos da Faculdade de Medicina da Universidade de São Paulo.

O apoio financeiro foi concedido sob a forma de bolsa de mestrado e auxílio à pesquisa pela Fundação de Amparo à Pesquisa do Estado de São Paulo (FAPESP) sob números 2010/01736-2 e 2009/52244-5. 
"Feliz aquele que transfere o que sabe e aprende o que ensina."

Cora Coralina 


\section{SUMÁRIO}

Lista de abreviaturas

Lista de tabelas

Lista de figuras

Resumo

Abstract

1. Introdução 1

$\begin{array}{lc}1.1 \text { Revisão da literatura } & 6\end{array}$

$\begin{array}{ll}\text { 2. Objetivos } & 13\end{array}$

3. Métodos 15

4. Resultados $\quad 34$

5. Discussão 69

$\begin{array}{ll}\text { 6. Conclusão } & 79\end{array}$

7. Referências bibliográficas $\quad 81$

8. Apêndices 


\section{LISTA DE ABREVIATURAS}

\begin{tabular}{|c|c|}
\hline${ }^{\circ} \mathrm{C}$ & Graus celsius \\
\hline$\mu \mathrm{g}$ & microgramas \\
\hline$\mu l$ & microlitros \\
\hline$\mu \mathrm{M}$ & micromolar \\
\hline AGCC & ácidos graxos de cadeia curta \\
\hline AGCL & ácidos graxos de cadeia longa \\
\hline AGCM & ácidos graxos de cadeia média \\
\hline AGPI & AG poli-insaturados \\
\hline AGPI n-3 & ácidos graxos poli-insaturados da família ômega 3 \\
\hline AGs & Ácidos graxos \\
\hline ANGPTL4 & (angiopoietin-like 4) \\
\hline ATCC & do Inglês American Type Culture Collection \\
\hline CD36 & (CD36 molecule-thrombospondin receptor) \\
\hline cDNA & DNA complementar \\
\hline CEP & Comitê de Ética em Pesquisa \\
\hline c-ErbB2 & homologo 2 do oncogene viral de leucemia eritroblástica \\
\hline $\mathrm{cm} 2$ & centímetros quadrados \\
\hline $\mathrm{CO} 2$ & Dióxido de carbono \\
\hline DEGs & genes diferencialmente expressos \\
\hline DEPEC & dietilpirocarbonato \\
\hline DHA & ácido docosahexaenoico \\
\hline DMEM & Dubelcco's Modified Eagle's Medium \\
\hline DMSO & dimetilsulfóxido \\
\hline DNA & ácido desoxirribonucléico \\
\hline dNTP & desoxiribonucleotídeos \\
\hline EPA & ácido eicosapentaenoico \\
\hline ER & receptor de estrógeno \\
\hline ERBB2 & v-erb-b2 erythroblastic leukemia viral oncogene homolog 2 \\
\hline FDR & False Discovery Rate \\
\hline FMUSP & Faculdade de Medicina da Universidade de São Paulo \\
\hline $\mathbf{g}$ & força da gravidade (aceleração centrípeta) \\
\hline GO & Gene Ontology \\
\hline $\mathrm{Hb} 4 \mathrm{a}$ & $\begin{array}{l}\text { linhagem celular epitelial mamária humana derivada de } \\
\text { mamoplastia imortalizada pela transfecção do antígeno T } \\
\text { grande do vírus SV40 }\end{array}$ \\
\hline \multicolumn{2}{|l|}{ HB4aC5.2 } \\
\hline HER-2 & receptor de fator de crescimento epidermal 2 \\
\hline INCA & Instituto Nacional do Câncer \\
\hline IPA & Ingenuity Pathway Analysis \\
\hline $\mathbf{M}$ & molar \\
\hline
\end{tabular}




$\begin{array}{ll}\text { mg } & \text { miligrama } \\ \text { mI } & \text { mililitro } \\ \text { NCBI } & \text { milimolar } \\ \text { ng } & \text { (National Center for Biotechnology Information) } \\ \text { nM } & \text { nanogramas } \\ \text { pb } & \text { nanometros } \\ \text { PM } & \text { pares de bases } \\ \text { PPARA } & \text { Perfect Match } \\ \text { PPARG } & \text { peroxisome proliferator-activated receptor alpha } \\ \text { PR } & \text { peroxisome proliferator-activated receptor gamma } \\ \text { RIN } & \text { receptor de progesterona } \\ \text { RMA } & \text { RNA Integrity Number } \\ \text { RNA } & \text { Robust Multiarray Average } \\ \text { RNAm } & \text { ácido ribonucléico } \\ \text { RPMI } & \text { ácido ribonucléico mensageiro } \\ \text { RT } & \text { meio de cultura } \\ \text { RT-qPCR } & \text { enzima Transcriptase Reversa } \\ & \text { reação da transcriptase reversa, seguida de reação em } \\ \text { SAM } & \text { cadeia da polimerase quantitativa } \\ \text { SFB } & \text { Significance Analysis of Microarrays } \\ \text { SKBR-3 } & \text { soro fetal bovino } \\ \text { SREBP } & \text { células luminais de adenocarcinoma de mama humano } \\ \text { UI } & \text { sterol regulatory element binding transcription factor } 2 \\ & \text { Unidade internacional }\end{array}$




\section{LISTA DE FIGURAS}

Figura 1 Elongação e dessaturação de ácidos graxos da Pag.9 família ômega 6 e ômega 3.

Figura 2 Esquema ilustrativo da sequência de

Pag.17 procedimentos realizados na primeira etapa do estudo

Figura 3 Esquema representativo de um gene com as

Pag.20 regiões de cobertura dos Genechips ${ }^{\circledR}$.

Figura $4 \quad$ Análise da integridade do RNA total utilizando o Pag.35 Bioanalyser.

Figura 5 Imagens obtidas pelo Scanner 3000 após a

Pag.36 hibridização das amostras.

Figura 6 Relação entre perfect mean e background mean nos Genechips ${ }^{\circledR}$

Pag.37

Figura 7 Relação "positivos versus negativos" nos

Pag.38 Genechips ${ }^{\circledR}$

Figura 8 Controles positivos de hibridização.

Pag.39

Figura 9 Controle de amplificação externo.

Pag. 40

Figura 10 Histograma de Sinal.

Pag.41

Figura 11 Box plots com média aproximada no valor 0.

Pag.42

Figura 12 Novo desenho de análise estatística com análise

Pag.44 pareada e com permutação.

Figura 13 Rede de ligações gênicas na linhagem HB4a;

Pag.47 DEGs.

Figura 14 Rede de ligações gênicas na linhagem HB4a. Pag.48 Ligação com PPARG.

Figura 15 Rede de ligações gênicas na linhagem

Pag.49 HB4a.Ligação com PPARA.

Figura 16 Rede de ligações gênicas na linhagem HB4a.Ligação com PPARD e PPARG.

Pag.50

Figura 17 Rede de ligações gênicas na linhagem HB4a.

Pag.51 DEGs hiperexpressos 
Figura 18 Rede de ligações gênicas na linhagem

HB4aC5.2.Ligações indiretas com AKT e ERK.

Figura 19 Rede de ligações gênicas na linhagem

Pag.53

HB4aC5.2.Ligações indiretas com TNF.

Figura 20 Rede de ligações gênicas na linhagem

Pag.54

HB4aC5.2.Genes hiperexpressos e hipoexpressos.

Figura 21 Rede de ligações gênicas na linhagem

HB4aC5.2.DEGs membrana celular.

Figura 22 Rede de ligações gênicas na linhagem SKBR-3. Pag.56 Ligações indiretas com TNF.

Figura 23 Rede de ligações gênicas na linhagem SKBR-3. Pag.57 DEGs metabolismo lipídico.

Figura 24 Estratégia para busca de genes diferencialmente expressos após o tratamento com DHA envolvidos com HER-2.

Figura 25 Box plots representativos da expressão gênica dos genes selecionados na linhagem HB4a por RT-PCR com significância estatística.

Figura 26 Box plots representativos da expressão gênica dos genes selecionados na linhagem HB4aC5.2 por RT-qPCR.

Figura 27 Box plots representativos da expressão gênica dos genes selecionados na linhagem SKBR-3 por RT-qPCR. 


\section{LISTA DE TABELAS}

Tabela 1 Especificações do GeneChip ${ }^{\circledR}$ Human Gene $1.0 \quad$ Pag.21 ST Array

Tabela 2 Genes diferencialmente expressos (DEGs) Pag.43 utilizando método SAM e RankProd.

Tabela 3 Genes diferencialmente expressos (DEGs) Pag.44 utilizando método SAM com análise pareada e com permutação

Tabela 4 DEGs pré selecionados na linhagem HB4a Pag.45

Tabela 5 DEGs pré selecionados na linhagem HB4aC5.2 Pag.46

Tabela 6 DEGs pré selecionados na linhagem SKBR-3 Pag.46

Tabela $7 \quad$ Genes selecionados para validação técnica por Pag.61 qRT PCR.

Tabela $8 \quad$ Primers forward e reverse desenhados para genes Pag.62 diferencialmente expressos selecionados para validação técnica.

Tabela 9 DEGs selecionados para validação técnica por RT- Pag.64 qPCR na linhagem HB4a

Tabela 10 Análise estatística do RT-qPCR em tempo real Pag.66 para os DEGs selecionados para validação técnica na linhagem HB4aC5.2.

Tabela 11 Análise estatística do RT-qPCR em tempo real Pag.68 para os DEGs selecionados para validação técnica na linhagem SKBR-3 


\section{RESUMO}

ALMEIDA D.F. Avaliação do perfil de expressão gênica de linhagens celulares do tecido mamário com diferentes níveis de expressão do receptor HER-2 tratadas com ácido docosahexaenoico. [dissertação]. São Paulo: Faculdade de Medicina, Universidade de São Paulo; 2013.

O câncer de mama permanece como segundo tipo de câncer mais frequente no mundo e o primeiro entre as mulheres. Tumores de mama podem ser categorizados pela expressão de receptores como o HER-2 (receptor de fator de crescimento epidermal 2). A hiperexpressão do receptor HER-2 é observada em cerca de 30\% dos carcinomas de mama, e está associada a prognósticos desfavoráveis. Os ácidos graxos poli-insaturados (AGPI), como os ácidos graxos ômega-3, parecem diminuir o risco de câncer de mama. O ácido docosahexaenoico (DHA), um tipo de AGPI ômega-3 parece ter o maior potencial antitumoral no câncer de mama. Alguns mecanismos de ação foram propostos para a ação do DHA no controle do câncer de mama, no entanto, faltam dados para elucidar os mecanismos moleculares do DHA no tecido mamário normal e cancerígeno. Dessa maneira, o objetivo desse trabalho foi avaliar a ação do DHA na modulação da expressão de genes em linhagem celular normal (HB4a), transformada (HB4aC5.2) e de carcinoma mamário humano (SKBR-3). As linhagens estudadas foram tratadas com $100 \mu \mathrm{M}$ de DHA ou controle (etanol) durante 72 horas. Após a extração de RNA realizamos a técnica de expressão gênica global (Microarray) para encontrar os genes diferencialmente expressos, em relação ao tratamento com DHA, em cada linhagem celular estudada. Na linhagem normal (HB4a) observamos 174 genes diferencialmente expressos $(p<0,01)$, sendo 136 hiperexpressos e 38 hipoexpressos, na linhagem celular transformada (HB4aC5.2) encontramos 208 genes diferencialmente expressos $(p<0,01)$, sendo 32 hiperexpressos e 176 hipoexpressos. A linhagem do carcinoma mamário (SKBR-3) apresentou 126 genes diferencialmente expressos $(p<0,01)$, sendo 48 hiperexpressos e 78 hipoexpressos. A análise ontológica destes genes permitiu identificar 
processos biológicos como: adesão celular, diferenciação celular e metabolismo lipídico. Concluímos que o DHA altera o perfil de expressão gênica de maneiras distintas em linhagem normal, transformada e de carcinoma mamário humano. Além disso, encontramos após o tratamento com DHA genes envolvidos com o metabolismo lipídico nas linhagens que hiperexpressam o receptor HER-2.

Descritores: Câncer de mama; ácidos graxos ômega 3; expressão gênica; nutrigênomica, receptores HER-2. 


\section{ABSTRACT}

ALMEIDA D.F. Evaluation of the gene expression profile of breast tissue cell lines with different expression levels of the HER-2 receptor treated with docosahexaenoic acid. [dissertation]. São Paulo: "Faculdade de Medicina, Universidade de São Paulo"; 2013.

Breast cancer remains the second most common cancer in the world and first among women. Breast tumors can be categorized by the expression of receptors such as HER-2. Overexpression of HER-2 receptor is associated with unfavorable prognosis. The polyunsaturated fatty acids (PUFAs) omega3 appears to decrease the risk of breast cancer. Docosahexaenoic acid (DHA), a type of omega-3 PUFAs, seems to have greater antitumor potential in breast cancer. However, the gene expression profile resulting from the action of DHA in breast cancer has not been elucidated yet. We aimed to examine the effects of DHA on normal breast cell line (HB4a), transformed cell line (HB4aC5.2) and breast cancer cell line (SKBR-3) and using a microarray approach. Cells were treated with $100 \mu \mathrm{M}$ of DHA for 72 hours. We identified 174, 208 and 126 differentially expressed genes after DHA treatment, in HB4a, HB4aC5.2 and SKBR3, respectively. Notably, the molecular pathways for the differentially expressed genes included those related to lipid metabolism, cell growth, molecular transport and cell-to-cell signaling. Where found genes related to overexpression of HER-2 after treatment with DHA. These genes involved in lipid metabolism and were down-expressed after treatment, suggesting a possible mechanism DHA in breast cancer by lipid metabolism control.

Descriptors: breast cancer; unsaturated fatty acids, gene expression; nutrigenomics, HER-2 receptors. 
O câncer de mama permanece como segundo tipo de câncer mais frequente no mundo e o primeiro entre as mulheres ${ }^{[1]}$. No Brasil, o número de casos de câncer de mama estimados para 2012 foi de $52.680^{[2]}$.

A história natural do câncer de mama envolve mudanças progressivas, refletidas por diferentes estágios clínicos e patológicos, de células luminais epiteliais que adquirem características fenotípicas. Estas permitem sua rápida proliferação, progressão para carcinoma in situ, invasão do tecido adjacente e metástase ${ }^{[3]}$.

O câncer de mama é referido como uma coleção de doenças caracterizadas pela presença de células malignas de diferentes tipos moleculares. Estes podem ser categorizados pela expressão de três receptores celulares: receptor de estrógeno (ER), receptor de progesterona $(P R)$, e o receptor de fator de crescimento epidermal 2 (HER-2; gene ERBB2 $)^{[4]}$.

A amplificação e hiperexpressão do receptor HER-2 são observadas em aproximadamente $30 \%$ dos carcinomas de mama, e estão associados a prognósticos desfavoráveis [5, 6]. A via de sinalização deflagrada pelos receptores HER-2 tem sido considerada como via regulatória central de processos envolvidos na proliferação e sobrevivência celular, mesmo na presença de sinais apoptóticos [7].

O aumento de receptores HER-2 também está associado ao aumento do potencial metastático com menor resposta ao tratamento ${ }^{[8]}$. O gene ERBB2, no momento, representa um dos mais importantes oncogenes no câncer de mama [5, 6, 9].

Admite-se que hábitos dietéticos desequilibrados sejam responsáveis pela origem de $1 / 3$ de tipos distintos de câncer ${ }^{[10]}$. A relação entre câncer de mama e dieta não está totalmente esclarecida ${ }^{[11]}$, porém, o alto consumo de gordura parece estar relacionado a um risco elevado deste tipo de câncer ${ }^{[12-}$ 16]. 
No entanto, alguns tipos de lipídios, incluindo tanto os ácidos graxos (AG) insaturados quanto os monoinsaturados, além dos $A G$ poli-insaturados (AGPI) como o ômega-3 (AGPI n-3), parecem diminuir o risco de câncer de mama $^{[17,18]}$. Os lipídios presentes no peixe, e principalmente no óleo de peixe, são os AGPI da família AGPI n-3, que incluem o ácido eicosapentaenoico (EPA) e o ácido docosahexaenoico (DHA ${ }^{[19]}$.

Diversos estudos epidemiológicos, experimentais in vivo e in vitro sugerem papel preventivo e terapêutico dos AGPI n-3 no câncer de mama ${ }^{[20-}$ 25]. Adicionalmente, alguns estudos demonstraram que os AGPI n-3 podem aumentar a sensibilidade à quimioterapia ${ }^{[26,27]}$ e inibir metástases no câncer

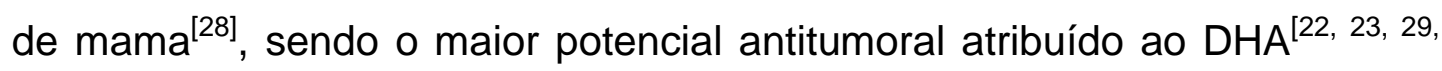
30]

O DHA incorpora-se na membrana celular e pode influenciar diretamente em vias de sinalização que controlam proliferação e morte celular ${ }^{[31,32]}$. No entanto, os mecanismos moleculares resultantes da ação do DHA não foram totalmente elucidados.

Nesse sentido vale ressaltar a importância de novas tecnologias para a compreensão dos mecanismos moleculares dos nutrientes. Elas permitiram aumentar nossa compreensão sobre como os nutrientes podem modular a expressão gênica e influenciar no metabolismo celular. Essa ciência é conhecida como Nutrigenômica. [33]

A Nutrigenômica utiliza tecnologias genômicas para desvendar a ação dos nutrientes na modulação de genes e proteínas e sua influencia no metabolismo celular e do organismo. A técnica mais utilizada na genômica até agora é transcriptômica, que permite a análise da expressão gênica de milhares de genes ao mesmo tempo.[33]

Existem evidências de que AG, em particular os insaturados, exercem muitos dos seus efeitos por meio da modulação da transcrição gênica regulando a atividade de fatores de transcrição, incluindo receptores nucleares. Particularmente, o DHA pode se ligar a fatores transcricionais, como a família PPAR (peroxisome proliferator-activated receptor alpha) e do 


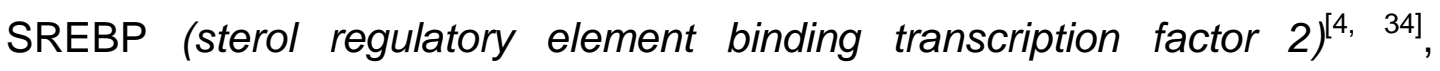
envolvidos no metabolismo de lipídeos e na homeostase do colesterol, tendo influência sobre genes que participam do ciclo celular, e no reparo de danos ao DNA ${ }^{[35]}$.

A mesma via deflagrada pelo HER-2 também é capaz de regular 0 fator de transcrição SREBP. A forma ativa da proteína SREBP favorece o aumento da expressão da HMG-CoA redutase, enzima marca-passo da síntese endógena de colesterol, implicando no aumento da produção endógena de colesterol.

O perfil gênico de diferentes linhagens de câncer de mama (MDA-MB 231, MDA-MB 435, MCF-7 e HCC2218) tratadas com AG n-3 (EPA e DHA) e AG n-6 (ácido araquidônico e ácido linoléico) foi analisada durante 6 e 24 horas. Os autores observaram que 35 genes se alteraram nas primeiras 6 horas de tratamento. Foram encontradas diferenças essenciais entre os AGPI na alteração da expressão gênica. Análises ontológicas mostraram diversos genes com funções na progressão do ciclo celular e apoptose. Vale ressaltar que nenhuma das linhagens de câncer de mama estudadas apresenta receptores HER-2 hiperexpressos ${ }^{[36]}$.

Pesquisas conduzidas pelo nosso laboratório utilizando células com hiperexpressão dos receptores HER-2, HB4aC5.2, mostraram que essas células apresentaram níveis elevados de colesterol e lipid rafts na membrana celular.

Os lipid rafts são microdominios na membrana celular com capacidade de incluir e excluir proteinas da membrana. São importantes em diversos processos celulares, principalmente na transdução de sinal. Para essa função é necessário que os níveis totais de colesterol e esfingolípides saturados, além de sua distribuição na membrana celular, estejam rigorosamente controlados. ${ }^{[37]}$ Adicionalmente, o agrupamento dos rafts pode ser favorecido se a concentração de seus componentes lipídicos (colesterol e esfingolípides saturados) aumentar e, consequentemente algumas 
proteinas, como por exemplo, os receptores da família HER podem ser hiperativadas, descontrolando a cascata de proliferação celular. ${ }^{[38]}$

Em pesquisa conduzida pelo nosso grupo mostrou em linhagem mamária transformada HB4aC5.2, após o tratamento com $100 \mu \mathrm{M}$ de DHA por 72 horas, a indução de apoptose e inibição da proteína Akt (principal proteína da via downstream dos receptores HER-2, envolvida com proliferação celular), por meio da desestruturação desses lipid rafts. ${ }^{[39]}$ No entanto, o perfil de expressão gênica resultante dessa alteração não foi investigado.

A hipótese da nossa pesquisa considera que células de câncer de mama com e sem hiperexpressão de HER-2 possam ser sensíveis à modulação na expressão gênica induzidos por DHA.

Ponderamos que nossa abordagem tem como vantagem avaliar 0 potencial efeito do DHA na expressão de múltiplos genes para esclarecer os mecanismos da ação do DHA na célula mamária normal, transformada e cancerígena. 


\subsection{1. Ácidos graxos ômega-3}

Ácidos graxos poli-insaturados (AGPI) são considerados uma subclasse de componentes bioativos (ver http://www.lipidmaps.org/), dividido em dois grupos (AG n-6 e n-3), e são estudados na prevenção do câncer. ${ }^{[40]}$

Os AG são ácidos carboxílicos representados pela fórmula $\mathrm{R}-\mathrm{CO}_{2} \mathrm{H}$, em que o radical $\mathrm{R}$ é geralmente uma cadeia hidrocarbônica, não ramificada, com número par de átomos de carbono, unidos por ligações simples ou duplas. Os AG podem ser classificados de acordo com o grau de saturação, número total de carbonos e pela essencialidade ${ }^{[41,42]}$.

O grau de saturação é caracterizado pelo número de duplas ligações: saturados (sem duplas ligações), monoinsaturados (uma dupla ligação e poli-insaturados (mais de uma dupla ligação). Os AG têm cadeias com distintos números de átomos de carbono e podem ser: AG de cadeia curta (AGCC - 2 a 4 carbonos), AG de cadeia média (AGCM - 6 a 12 carbonos) e $A G$ de cadeia longa (AGCL - 14 a 22 carbonos) ${ }^{[41,42]}$.

A essencialidade dos AG é determinada pela capacidade de serem produzidos bioquimicamente pelo organismo. Os mamíferos podem sintetizar AG a partir de acetil-CoA, por meio da síntese de novo de AGs. O produto final da enzima AG sintetase é o ácido palmítico (16:0), o qual pode ser elongado a ácido esteárico (18:0) e a outros AG saturados de cadeia longa. A enzima delta 9 dessaturase, presente em plantas e animais, introduz uma dupla ligação entre o carbono 9 e 10, convertendo o ácido esteárico em oleico (18:1, n-9 ou $\omega$-9), com uma única insaturação na nona posição a partir do hidrocarboneto terminal. Estes $A G$, além de serem sintetizados pelos mamíferos, também são obtidos pela dieta. [43] 
No entanto, há um grupo de AG, denominados essenciais, que só podem ser obtidos pela dieta ${ }^{[44]}$, devido à ausência, em mamíferos, de enzimas para a sua biossíntese. As principais insaturações destes AGs essenciais estão na terceira (n-3 ou $\omega-3$ ) ou sexta posição (n-6 ou $\omega-6)$, a partir da extremidade metil (distal) ${ }^{[43]}$.

Os ácidos linoleico (C18:2 n-6, [LA]) e y-linolênico (C18:3 n-6, [DGLA]) são precursores do ácido araquidônico (C20:4 n-6, [AA]) e pertencem à família dos AG n-6. Os AG essenciais que pertencem à família n-3 são os ácidos a -linolênico (C18:3 n-3 [ALA]), precursores de eicosapentaenoico (C20:5 n-3, [EPA]) e docosahexaenoico (C22:6 n-3, [DHA]). As células animais podem apenas converter o ALA em outros AG da mesma família $n-$ 3, como o EPA e DHA. Por sua vez, o y-linolênico dá origem ao ácido araquidônico da mesma família $n-6$. Com isso, AGs de famílias diferentes não se interconvertem (Figura 1) ${ }^{[41,43,45]}$.

Uma das principais características do AG n-3 é a sua capacidade de incorporação na membrana celular, desencadeando diversas respostas celulares. Os AG insaturados incorporam-se na posição sn-2 de fosfolipídios da membrana celular de forma competitiva, com graus de afinidade que respeitam a ordem n-3>n-6>n-9, influenciando de maneira distinta sua estrutura e a função de diferentes receptores, transportadores, enzimas e canais iônicos a ela relacionados. ${ }^{[46]}$ Os AG LA e ALA podem ser obtidos a partir de fonte vegetal e animal, sendo encontrados em maior quantidade nas fontes vegetais. Óleos de milho, canola e soja são fontes significativas de AG n-6 e óleo de linhaça e semente de chia são exemplos de fontes vegetais de ALA. Os AG EPA e DHA, por sua vez, podem ser encontrados em alimentos de origem marinha, como óleo de microalga, óleo de peixe, salmão, sardinha, arenque e cavalinha ${ }^{[45]}$. 


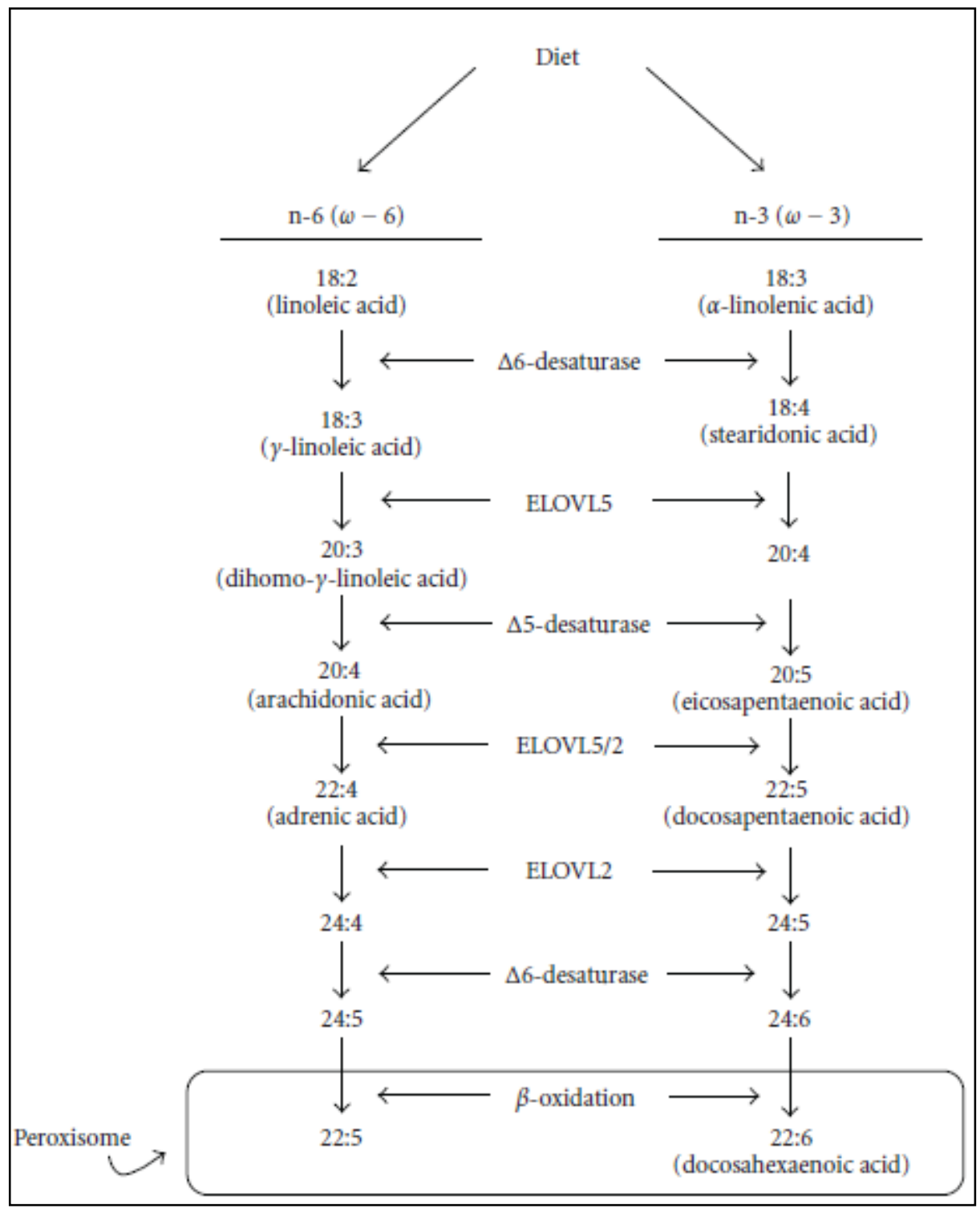

Figura 1: Elongação e dessaturação de AGs n-6 e n3. As enzimas delta 6 dessaturase ( $\Delta 6$-dessaturase) e delta 5 dessaturase ( $\Delta 5$-dessaturase) atuam na dessaturação de ácidos graxos poli-insaturados. Essas reações ocorrem no retículo endoplasmático. A formação do DHA envolve a atuação das enzimas elongase, delta 4 e delta 6 dessaturase, que nos peroxissomos sofrem a remoção de dois átomos de carbono. A eficiência global de conversão de ALA (alfa linoleico) é baixa. ${ }^{[45,47,48]}$ ELOVL2: elongation of very long chain fatty acids protein 2; ELOVL5: elongation of very long chain fatty acids protein 5 


\subsubsection{Câncer de mama, expressão gênica e AG n-3}

O câncer é um termo geral que representa mais de 100 doenças, e cada tipo apresenta etiologia própria. O câncer de mama continua a ser um problema de saúde pública com mais de um milhão de casos de incidentes por ano no mundo, sendo quase a metade na América do Norte e na Europa. ${ }^{[49]} \mathrm{O}$ prognóstico desta doença depende das características do tumor e da qualidade dos tratamentos. Estes tratamentos consistem em cirurgia, quimioterapia e depois manipulação hormonal, para evitar ou retardar o aparecimento de metástases ${ }^{[50]}$

Segundo o Instituto Nacional do Câncer (INCA), o número estimado para 2012 foi de 518.510 casos novos de câncer no Brasil, incluindo os casos de pele não melanoma, que é o tipo mais incidente para ambos os sexos (134 mil casos novos), seguido por próstata (60 mil), mama feminina (53 mil), cólon e reto (30 mil), pulmão (27 mil), estômago (20 mil) e colo do útero (18 mil) ${ }^{[51]}$.

Fatores dietéticos podem contribuir para a carcinogênese mamária. A progressão e o controle dessa doença parecem estar relacionados a hábitos alimentares, consumo de gorduras, carnes, frutas, vegetais, fibras fitoestrógenos e outros componentes dietéticos. A importância da dieta na abordagem preventiva do câncer de mama já é conhecida. No entanto ainda faltam dados relacionando o componente alimentar, o mecanismo e a ação no combate ao câncer de mama ${ }^{[40]}$. Embora existam inconsistências, estudos populacionais têm mostrado que o consumo de uma dieta rica em AG n-3 pode prevenir diversos tipos de câncer, incluindo os da mama ${ }^{[52-54]}$ próstata ${ }^{[55]}$ e cólon ${ }^{[56]}$. Embora muitos destes estudos tivessem sido feitos com base em dados de questionários sobre ingestão dietética ou estimativas baseadas no consumo nacional, alguns têm usado a composição de AGs nos tecidos como medida de exposição a gorduras dietéticas. 
O estudo EURAMIC é um dos maiores a fornecer provas de que o equilíbrio entre AGPI n-3 e n-6 tem papel importante no câncer de mama ${ }^{[57}$, 58].

Estudos experimentais têm observado que AG n-3 podem inibir a formação e o crescimento dos tumores de mama em modelos animais ${ }^{[59-61]}$. Uma série de mecanismos têm sido propostos para as ações anticâncer dos AG n-3, incluindo supressão de transformação neoplásica, inibição da proliferação celular, aumento da apoptose e antiangiogênese ${ }^{[52,62-65]}$. No entanto, poucos estudos relatam a expressão gênica global resultante da ação dos AG n-3.

Foi avaliado o perfil de expressão gênica em células mononucleares do sangue periférico (PBMCs) de indivíduos idosos saudáveis após consumo de diferentes AGs. A intervenção foi em 26 semanas com suplementação diária de 0,4 gramas de AG n-3 ( EPA + DHA) ou uma dose maior de 1,8 gramas de AG n-3 ( EPA + DHA).O consumo diário de 1,8g AG n-3 resultou em alterações em cerca de 1000 genes enquanto que no grupo de controle (óleo de girassol rico em ácido oleico) alterou cerca de 300 genes. A maior parte das alterações AG n-3 foi relacionada a diminuição na expressão de genes envolvidos em vias imunológicas e vias de desenvolvimento da aterosclerose. ${ }^{[3]}$

Em câncer de mama, foi realizado estudo em linhagens celulares de câncer de mama (MDA-MB-231, MCF-7 e HCC2218) tratadas com AG n-3 e n-6 durante 6 e 24 horas, verificou-se que 35 genes foram alterados nas primeiras 6 horas de tratamento. Após o tratamento com AG n-3 houve superexpressão do gene DUSP2 (Dual specificity phosphatase 2) que codifica a proteína envolvida na regulação negativa de proteínas quinases ativadas por mitógeno (MAPK / ERK, SAPK / JNK, p38), regulando a proliferação e diferenciação celular.

Outros genes que apresentaram hiperexpressão após o tratamento com AG n-3 foram: ITGB4 (Integrin, beta 4), considerado um importante biomarcador para terapia do câncer de mama, regulador de crescimento 
celular e sinalização célula-célula; SLC26A4 (Solute carrier family 26, member 4), que codifica proteína envolvida no transporte de íons, considerada fator inibidor do crescimento de tecido mamário maligno ${ }^{[36]}$.

Verificamos a ausência de dados consistentes nas alterações moleculares de AG n-3 nas células mamárias normais e tumorais. 
2. Objetivos 


\subsection{Objetivo Geral}

Verificar a ação do ácido docosahexaenoico (DHA) na modulação da expressão de genes em linhagens normal, transformada e de carcinoma mamário humano.

\subsection{Objetivos específicos}

a) Encontrar os genes diferencialmente expressos entre o grupo controle e grupo tratado com DHA para as diferentes linhagens celulares mamárias;

b) Encontrar genes envolvidos com a via do receptor HER-2 após o tratamento com DHA; 
3. Métodos 


\subsection{Comitê de Ética}

O trabalho foi submetido e aprovado pelo Comitê de Ética em Pesquisa da Faculdade de Medicina da Universidade de São Paulo (CEPFMUSP) (protocolo $n^{\circ}$ 026/10).

\subsection{Planejamento experimental}

As linhagens celulares escolhidas para o presente estudo foram HB4a, HB4aC5.2 e SKBR-3. As linhagens HB4a e HB4aC5.2 foram doadas pelo pesquisador Michael J. O'Hare do Laboratório de Câncer de Mama da Universidade de Londres e Instituto Ludwig de Pesquisa em Câncer de Londres. Estudos desenvolvidos pelo grupo de O'Hare mostraram que a linhagem HB4aC5.2 foi derivada da transfecção da linhagem HB4a com o cDNA full lenght correspondente ao receptor HER-2 [66]. Enquanto a linhagem HB4a apresenta níveis basais do receptor HER-2, a linhagem HB4aC5.2 expressa níveis equivalentes aos da linhagem SKBR-3, a qual apresenta constitutivamente altos níveis desse receptor $\left(10^{6}\right.$ receptores/célula) ${ }^{[67]}$.

O uso da linhagem HB4aC5.2, planejada especificamente para hiperexpressar HER-2, permite analisar células imortalizadas com fenótipo estritamente luminal e, por se assemelhar à sua linhagem de origem, HB4a, permite também observar efeitos específicos da hiperexpressão do HER-2.

A linhagem tumoral SKBR-3, além da hiperexpressão do receptor HER-2, apresenta fenótipo invasivo e metastático, ou seja, apresenta múltiplas aberrações genéticas. A referida linhagem foi adquirida do ATCC (American Type Culture Collection $n^{\circ}$ HTB-30). 


\subsubsection{Cultura celular}

As linhagens (HB4a, HB4aC5.2, SKBR-3) foram tratadas com $100 \mu \mathrm{M}$ de etanol (veículo de diluição do AG n-3), $100 \mu \mathrm{M}$ de DHA durante 72 horas. A Figura 2 ilustra o fluxograma da cultura celular desse estudo.

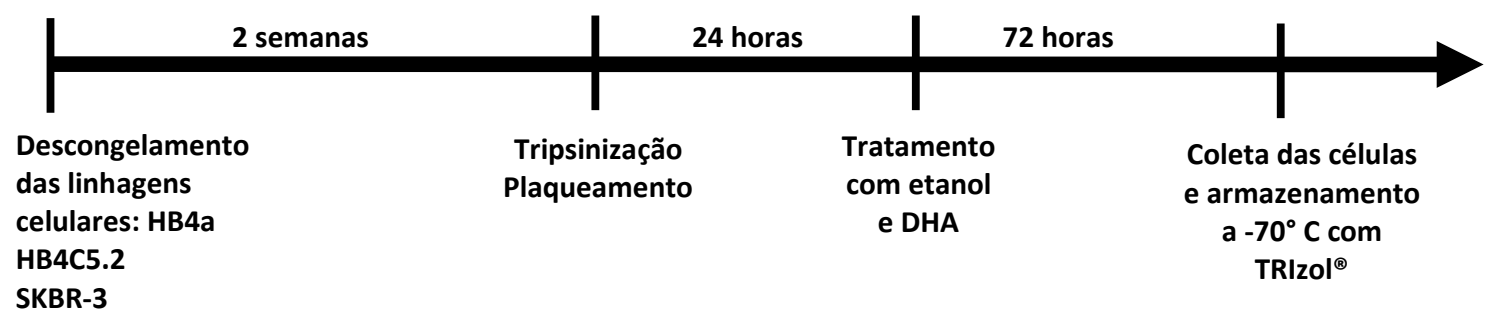

Figura 2: Esquema ilustrativo da sequência de procedimentos realizados na primeira etapa do estudo.

\subsubsection{Grupos experimentais}

\section{Linhagem de Células Epiteliais Normais da Glândula Mamária - HB4a}

As células luminais HB4a são clones não-transformados e nãotumorigênicos derivados do tecido epitelial mamário humano, além de apresentarem marcadores e comportamento semelhante ao tecido de origem $^{[7]}$. As células foram mantidas em meio RPMI 1640® (Gibco), acrescido de $10 \%$ de soro fetal bovino (SFB, Invitrogen), insulina, ampicilina, hidrocortisona e gentamicina e foram incubadas a $37^{\circ} \mathrm{C}$, em atmosfera de $95 \%$ e com $5 \%$ de $\mathrm{CO}_{2}{ }^{[7]}$.

\section{Linhagem de Células Epiteliais da Glândula Mamária - HB4aC5.2}

As células luminais HB4aC5.2 são clones derivados da linhagem HB4a transformados pela hiperexpressão de receptores HER-2. Elas apresentam fenótipo transformado, são sensíveis a hormônios e fatores de crescimento, porém sem potencial agressivo ${ }^{[7]}$. As células foram mantidas em meio RPMI 1640® (Gibco), acrescido de 10\% de SFB (Invitrogen), 
insulina, ampicilina, hidrocortisona e gentamicina e foram incubadas a $37^{\circ} \mathrm{C}$, em atmosfera de 95\% e com $5 \%$ de $\mathrm{CO}_{2}{ }^{[7]}$.

\section{Linhagem de Células de Adenocarcinoma de Mama - SKBR-3}

SKBR-3 são células luminais de adenocarcinoma de mama humano que apresentam fenótipo invasivo, metastático, ausência de receptores de estrógeno e hiperexpressão de receptor HER-2 ${ }^{[67]}$. As células foram mantidas em meio RPMI 1640® (Gibco), acrescido de 10\% de SFB (Invitrogen), glutamina, ampicilina, estreptomicina e fungizona e foram incubadas a $37^{\circ} \mathrm{C}$, em atmosfera de $95 \%$ e com $5 \%$ de $\mathrm{CO}_{2}{ }^{[7]}$.

\subsubsection{Viabilidade celular}

A viabilidade das linhagens foi avaliada utilizando método de exclusão por azul de Tripan ("Tripan Blue", Sigma). Todos os experimentos foram realizados com amostras que apresentaram viabilidade celular superior a $95 \%$.

\subsubsection{Plaqueamento}

As linhagens celulares HB4a, HB4aC5.2 e SKBR-3 foram cultivadas nas condições estabelecidas e após atingirem $80 \%$ de confluência foram tripsinizadas com 0,5\% Trypsin-EDTA $® 1$ X (Gibco) inativada com RPMI ${ }^{\circledR}$ suplementado com 10\% SFB (Invitrogen). Após serem homogeneizadas com esse meio, as células em suspensão foram finalmente retiradas da garrafa e colocadas em tubo falcon para serem centrifugadas por 2 minutos a $2000 \mathrm{x}$ g. Posteriormente, $1 \times 10^{6}$ células foram plaqueadas e cultivadas em meio apropriado para cada linhagem acrescida de etanol (células controle) ou de $100 \mu \mathrm{M}$ de DHA durante 72 horas. Óspo tratamento, as células foram coletadas e armazenadas a $-70^{\circ} \mathrm{C}$ com TRIzol® (Invitrogen) para posterior extração e purificação do RNA total. 


\subsubsection{Tratamento das linhagens com DHA}

As linhagens celulares foram tratadas durante 72 horas com etanol (controle da diluição do DHA) ou 1par de DHA (cis-4,7,10,13,16,19 Docosahexaenoic acid- D2534- Sigma). A porcentagem de etanol foi sempre menor que $0,05 \%$ do volume total de meio ${ }^{[30,68]}$. A concentração de DHA e o tempo de tratamento foram padronizados em estudos anteriores desenvolvidos em nosso laboratório (Projeto FAPESP n09/52244-5).

A confluência das células nas garrafas foi mantida em torno de 70\%80\% da área total. Esse controle foi realizado com o objetivo de evitar a ocorrência de alterações na progressão do ciclo decorrentes das condições do próprio ambiente de cultura, como a privação de nutrientes, que pode estar diretamente relacionada ao nível de confluência das células.

\subsubsection{Coleta das células e armazenamento a $-70^{\circ} \mathrm{C}$ com TRIzol ${ }^{\circ}$ (Invitrogen)}

Após o tratamento das linhagens HB4a, HB4aC5.2 e SKBR-3 como descrito anteriormente, o meio foi retirado das garrafas e as células aderidas foram cuidadosamente lavadas por cerca de 30 segundos em PBS (Na2HPO4 10mM, NaCl 1,37 mM, KCl 27 mM, KH2PO4 2mM). Após a retirada do PBS, foi adicionado $2 \mathrm{~mL}$ de TRIzol ${ }^{\circledR}$ (Invitrogen) sobre a camada celular e, com a ajuda de um CellScraper ${ }^{\circledR}$ (TRP), o material lisado foi coletado em micro-tubo de 1,5 mL. As amostras foram armazenadas a $70^{\circ} \mathrm{C}$ até o momento da extração de RNA total.

Para análise da expressão diferencial de transcritos, as amostras de RNA foram processadas de acordo com as recomendações do GeneChip ${ }^{\circledR}$ Human Gene 1.0 ST Array. 


\subsubsection{Perfil de expressão gênica global (Microarray)}

\subsubsection{Características dos GeneChips ${ }^{\circledR}$}

Para a construção dos GeneChips $®$ Human Gene 1.0 ST Array foram utilizados vários bancos públicos, tais como GenBank, RefSeq e Ensembl.

As sequências de oligonucleotídeos (sondas) selecionadas correspondem a regiões distribuídas ao longo do gene. Com o termo denominado "whole-transcript (WT)", esses GeneChips ${ }^{\circledR}$ oferecem uma cobertura mais completa do que outros GeneChips ${ }^{\circledR}$ desenhados na porção 3' do transcrito alvo. Podemos observar as diferenças na construção dos GeneChips ${ }^{\circledR}$ na Figura $3^{[69]}$.

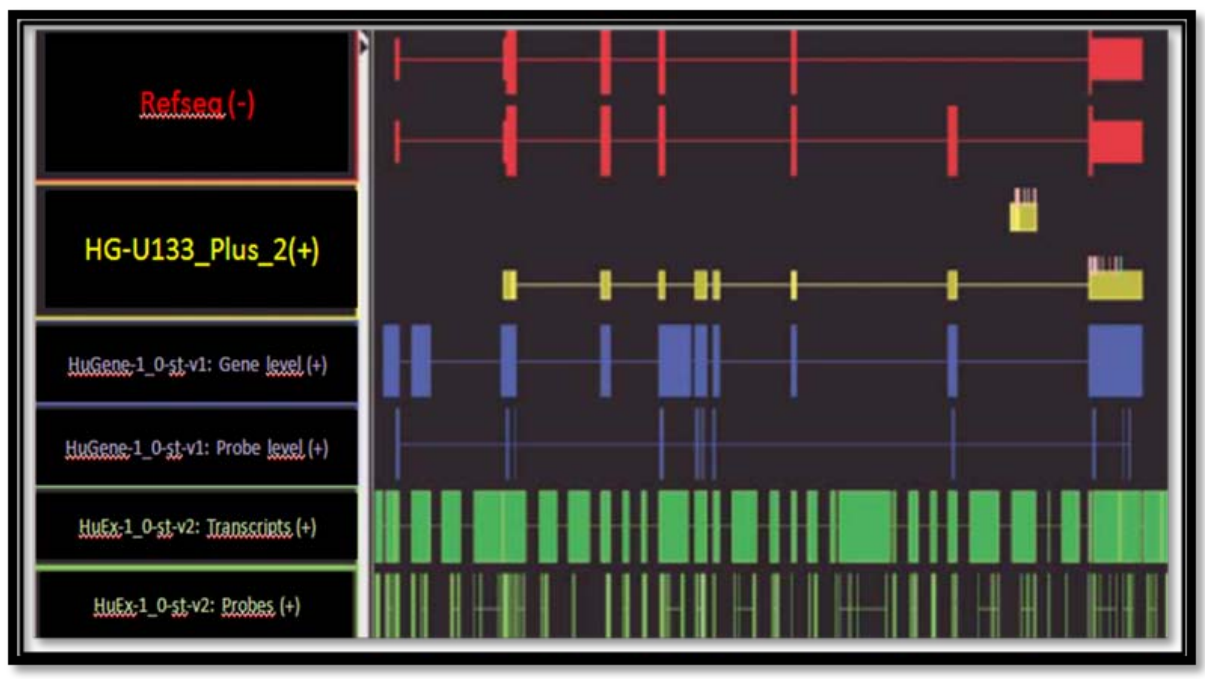

Figura 3: Esquema representativo de um gene com as regiões de cobertura dos GeneChips ${ }^{\circledR}$ desenhadas por barras coloridas. Em lilás observamos o GeneChips ${ }^{\circledR}$ utilizado HuGene-1_0-st-v1:Gene Level $(+)^{[69]}$.

O GeneChip ${ }^{\circledR}$ Human Gene 1.0 ST Array contém sequências de oligonucleotídeos representativos de mais de 28.000 transcritos humanos. Os transcritos são representados por "grupos de sondas", os quais correspondem a 26 pares de sondas. Cada "grupo de sondas" pode reconhecer diferentes transcritos de um mesmo gene ou transcritos correspondentes a genes diferentes. Os pares de sondas são constituídos 
apenas por sondas Perfect Match (PM). O Background é estimado utilizando um grupo de 17.000 sondas genéricas de erros. Controles padrão de poli-A e controles de hibridização são representados nos GeneChips ${ }^{\circledR}$ para permitir a solução de problemas experimentais durante o processo ${ }^{[69]}$. Outros detalhes da construção dos GeneChips ${ }^{\circledR}$ podem ser visualizados na Tabela 1.

Tabela 1: Especificações do GeneChip® Human Gene 1.0 ST Array ${ }^{[69]}$

\begin{tabular}{|c|c|}
\hline \multicolumn{2}{|c|}{ Especificações - GeneChip $®$ Human Gene 1.0 ST Array } \\
\hline Número de array & 1 \\
\hline Formato do array & 169 \\
\hline Características do tamanho & $5 \mu \mathrm{m}$ \\
\hline Comprimento da sonda & 25-oligonucleotídeos/sonda \\
\hline $\begin{array}{l}\text { Número total de sondas } \\
\text { distintas }\end{array}$ & 764.885 \\
\hline $\begin{array}{l}\text { Resolução } \\
\text { (número de sondas por gene) }\end{array}$ & 26 (média) \\
\hline Número estimado de genes & 28.869 \\
\hline $\begin{array}{l}\text { Controles positivos } \\
\text { (genes expressos } \\
\text { constitutivamente) }\end{array}$ & $\begin{array}{l}1.195 \text { grupos de sondas (nível } \\
\text { éxon) de supostos genes } \\
\text { constitutivos }\end{array}$ \\
\hline Controles Negativos & $\begin{array}{l}2.904 \text { grupos de sondas (nível } \\
\text { íntron) a partir de genes } \\
\text { supostamente constitutivos }\end{array}$ \\
\hline Controles de Hibridização & bioB, bioC, bioD, Cre \\
\hline Sondas de "background" & Grupo antigenomico \\
\hline Controle de Poli-A & Dap, lys, phe, thr \\
\hline $\begin{array}{l}\text { Quantidade de material total } \\
\text { inicial recomendado }\end{array}$ & 100ng RNA total \\
\hline
\end{tabular}




\subsubsection{Extração e purificação do RNA total}

A extração de RNA total foi realizada por meio da metodologia de TRIzol ${ }^{\circledR}$ (Invitrogen). As amostras armazenadas a $-70^{\circ} \mathrm{C}$ foram descongeladas e, em seguida, adicionou-se $200 \mu \mathrm{L}$ de clorofórmio e as amostras foram homogeneizadas. Após 10 minutos a temperatura ambiente, as amostras foram centrifugadas durante 15 minutos a $4^{\circ} \mathrm{C}$ e $12.000 \times \mathrm{g}$. $\mathrm{O}$ sobrenadante foi transferido para outro micro-tubo para adição de $500 \mu \mathrm{L}$ de isopropanol (mesmo volume do sobrenadante). As amostras foram homogeneizadas por 2 minutos e deixadas à temperatura ambiente por 20 minutos para iniciar a precipitação. Em seguida, as amostras permaneceram a $-20^{\circ} \mathrm{C}$ por uma noite para permitir a precipitação do RNA total.

No dia seguinte, as amostras foram centrifugadas durante 30 minutos a $4^{\circ} \mathrm{C}$ e $14.000 \times \mathrm{g}$. O sobrenadante foi descartado para adição de $1 \mathrm{~mL}$ de etanol $70 \%$, seguida de centrifugação por 2 minutos a $4^{\circ} \mathrm{C}$ e $14.000 \times$ g. Este processo foi repetido por mais duas vezes. O excesso de etanol foi retirado e o precipitado foi seco por 2 minutos em banho seco a $42^{\circ}$ C. A ressuspensão do precipitado de RNA total foi feita em $21 \mu \mathrm{L}$ de água DEPC. Para facilitar a ressuspensão, os tubos foram deixados em banho seco a $55^{\circ} \mathrm{C}$ durante 10 minutos.

Após a extração, a purificação do RNA total foi realizada utilizando o Rneasy mini kit ( $\mathrm{n}^{\circ}$ 74104, Qiagen), de acordo com a descrição do fabricante. Para esse procedimento, foram utilizados $10 \mu \mathrm{g}$ de RNA total em o volume final de $100 \mu \mathrm{L}$. Após a adição de $350 \mu \mathrm{L}$ de tamão RLT, foi adicionado $250 \mu \mathrm{L}$ de etanol $100 \%$ e a sథ̣̂̃o final transferida para uma coluna Rneasy Mini spin, acoplada a um tubo coletor, sendo submetida à centrifugação por 15 segundos a 8000 x g. Em seguida, o eluato foi descartado e $500 \mu \mathrm{L}$ de tampão RPE foram aplicados no centro da coluna, submetendo-a à nova centrifugação (15 segundos e 8000 x g).

Após descarte do eluato, foi adicionado mais $500 \mu \mathrm{L}$ de tamp̃o RPE sobre a coluna, submetendo-a à centrifugação por 2 minutos a 8000 x g. 
A seguir, a coluna foi colocada em um novo tubo de 1,5 mL e, após a aplicação de 25-30 $\mu \mathrm{L}$ de água livre de RNAses, a amostra foi centrifugada por 1 minuto a 8000 x g para eluição e quantificação do RNA.

\subsubsection{Quantificação de RNA total}

A quantificação, ou seja, a concentração do RNA total foi obtida pela leitura da absorbância nos comprimentos de onda de 260 e 280 nM pelo espectrofotômetro NanoDrop (ND-1000 UV-Vis Spectrophotometer, NanoDrop Technologies), sendo a pureza avaliada pela razão 260/280. Foram consideradas amostras de pureza aceitável quando os valores dessa razão se situaram entre 1.8 e 2.1 .

\subsubsection{Integridade do RNA total}

Após a extração e a purificação do RNA total foi realizada a análise da integridade do RNA por meio do aparelho de eletroforese por microcapilaridade, Bioanalyzer (Model 2100; Agilent Technologies, Palo Alto, CA). Com a ajuda de uma "estação de preparação", os canais do chip são preenchidos com o gel contendo corante, que se intercala diretamente com o ácido nucléico. Como princípio, este instrumento detecta as biomoléculas pela fluorescência induzida pelo laser a 670-700nm [70]. A imagem de um eletroferograma é gerada e a qualidade das amostras é dada pelo RIN (RNA Integrity Number), o qual varia de 0 a 10 em ordem crescente de integridade. Assim, para as amostras de RNA total e amplificado, são esperados valores altos de RIN $(>7,0)$ e para as amostras fragmentadas, valores menores (em torno de 2,0). Foram utilizados para experimentos de amplificação e hibridização nos GeneChips @ 1.0 ST Array (Affymetrix) amostras com valores de RIN > 8 . 


\subsubsection{Preparo das amostras para hibridização}

Para o preparo das amostras para hibridização no GeneChip ${ }^{\circledR} 1.0$ ST Array(Affymetrix)utilizamos o protocolo de marcação recomendado pelo fabricante com 100ng de RNA total, denominado GeneChip ${ }^{\circledR}$ Whole Transcript Sense Target Labeling Assay.

\subsubsection{Preparação da diluição dos controles Poly-A RNA}

Para este procedimento utilizamos oKit GeneChip ${ }^{\circledR}$ Poly-A de Controle de RNA (cat. $\mathrm{n}^{\circ}$ 900433, Affymetrix, Santa Clara, CA).A qualidade do RNA da amostra inicial é essencial para o sucesso da análise de expressão gênica global, assim como descrito no manual do fabricante foi utilizado $1 \mu \mathrm{g}$ de RNA total. Os controles de RNA Poly-A são fornecidos em quatro diferentes concentrações de estocagem. O tampão de diluição é fornecido com o kit e foi diluído conforme recomendação do fabricante. Para a primeira diluição (1:20) foi utilizado $4 \mathrm{~L}$ do reagente Poly-A RNA Control Stock adicionado a $38 \mu \mathrm{L}$ do reagente Poly-A Control Die Buffer,. Para a segunda diluição (1:50) foi utilizado $2 \mathrm{LL}$ da $1^{\circ}$ diluç̧ão adicionado a $98 \mu \mathrm{L}$ do reagente Poly-A Control Die Buffer. Para a terceira diluição (1:50) foi adicionado $2 \mu \mathrm{L}$ da $2^{\circ}$ dẹaáo ad icionado a $98 \mu \mathrm{L}$ do reagente Poly-A Control Die Buffer. Foi adicionado $2 \mu \mathrm{L}$ da terceira dilçâo ao volume de amostra contendo $2 \mu \mathrm{g}$ de RNA total para compor a mistura de RNA Total/RNA Poly-A.

\subsubsection{Preparação do Mix T7-(N)6 Primers/Controle Poly-A}

Preparamos uma diluição de $250 \mathrm{ng} \mu \mathrm{L}$ dos Primers T7-(N)6 (a partir de $2,5 \mu \mathrm{g} / \mu \mathrm{L}$ do estocado) conforme indicado pelo fabricante. Para isso, foram adicionados $2 \mu \mathrm{L}$ do Primer concentrado T7-(N)6 a $6 \mu \mathrm{L}$ da terceira diluição do Controle Poly-A e $12 \mu \mathrm{L}$ de água livre de RNAse para um volume 
total de $20 \mu \mathrm{L}$. Para cada amostra contendo RNA total é necessário acrescentar $2 \mu \mathrm{L}$ do mix T7.

Em seguida, foram acrescentados $2 \mu \mathrm{L}$ do mix T7 nas amostras contendo a mistura de RNA Total/RNA Poly-A. O volume final foi de $5 \mu \mathrm{L}$ (quando necessário o volume final foi acrescentado de água livre de RNAse). Após homogeneizar esta solução as amostras foram incubadas por 5 minutos a $70^{\circ} \mathrm{C}$ e por 2 minutos a $4^{\circ} \mathrm{C}$.

\subsubsection{Síntese da $1^{\circ}$ fita de cDNA ( $1^{\circ}$ Ciclo)}

Nesta etapa foi utilizado o Kit GeneChip® WT cDNA Synthesis(cat. $\mathrm{n}^{0}$ 900673, Affymetrix, Santa Clara, CA) conforme descrito pelo fabricante. Foi preparada a solução Master Mix $1^{\circ}$ Ciclo. Em um micro-tubo foi adicionado 2 $\mu \mathrm{L}$ do reagente $5 X 1^{\text {st }}$ Strand Buffer, $1 \mu \mathrm{L}$ do reagente $\operatorname{DTT}(0,1 \mathrm{M}), 0,5 \mu \mathrm{L}$ do reagente $d N T P$ Mix (10nM), 0,5 $\mu \mathrm{L}$ do reagente RNase Inhbitor e por fim 1 $\mu \mathrm{L}$ do reagente SuperScript $I I$, com o volume final de $5 \mu \mathrm{L}$. Foram adicionados $5 \mu \mathrm{L}$ da solução Master Mix $1^{\circ}$ Ciclo, $1^{\circ}$ Fita ao tubo contendo o concentradoRNA total/ Controle de Poly-A/T7-(N)6 Primers, com um volume total de $10 \mu \mathrm{L}$, as amostras foram homogenizadas. A reação foi incubada por 10 minutos a $25^{\circ} \mathrm{C}$, por 60 minutos a $42^{\circ} \mathrm{C}$ e por 10 minutos a $70^{\circ} \mathrm{C}$. A reação foi resfriada $4^{\circ} \mathrm{C}$ por 2 minutos.

\subsubsection{Síntese da $2^{\circ}$ fita de cDNA ( $1^{\circ}$ Ciclo)}

Para a síntese da $2^{\circ}$ fita foi adicionado $4,8 \mu \mathrm{L}$ de água RNase-free, 4,0 $\mu \mathrm{L}$ de $\mathrm{MgCl}_{2}$ (17,5mM), 0,4 $\mu \mathrm{L}$ dNTP Mix (10nM), 0,6 $\mu \mathrm{L}$ DNA Polymerase I e 0,2 $\mu \mathrm{L}$ de RNase H. Foram adicionados $10 \mu \mathrm{L}$ do Master Mix $1^{\circ}$ ciclo, $2^{\circ}$ fita ao tubo da reação de Síntese da $1^{\circ}$ fita de cDNA, tendo um volume final da reação de $20 \mu \mathrm{L}$, as amostras foram homogeneizadas e centrifugadas rapidamente.A reação foi incubada por 120 minutos a $16^{\circ} \mathrm{C} \mathrm{e}$ por 10 minutos a $75^{\circ} \mathrm{C}$. Em seguida a reação foi esfriada por 2 minutos a $4^{\circ} \mathrm{C}$. 


\subsubsection{Transcrição In vitro}

Para este procedimento utilizamos o Kit GeneChip ${ }^{\circledR}$ WT CDNA Amplification(cat. $n^{\circ} 900673$, Affymetrix, Santa Clara, CA) e o Kit GeneChip ${ }^{\circledR}$ Sample Cleanup Module(cat. $\mathrm{n}^{0} 900371$, Affymetrix, Santa Clara, $\mathrm{CA})$ conforme descrito e fornecido pelo fabricante. Em um micro-tubo foi preparada a solução IVT Master Mix. Foi adicionado $5 \mu \mathrm{L}$ do reagente $10 X$ IVT Buffer, $20 \mu \mathrm{L}$ do IVT NTP Mix e $5 \mu \mathrm{L}$ do IVT Enzyme Mix. Com o volume total de $30 \mu \mathrm{L}$. Foi transferido $30 \mu \mathrm{L}$ do IVT Master Mix em cada amostra da reação deSíntese da $2^{\circ}$ fita de cDNA.Após homogeneizar asamostras,a reação foi incubada por 16 horas a $37^{\circ} \mathrm{C}$.

\subsubsection{Purificação do CRNA ( $1^{\circ}$ Ciclo)}

Para a purificação do cRNA utilizamos as colunas de cRNA Cleanup Spin do Kit GeneChip ${ }^{\circledR}$ Sample Cleanup Module. Foi adicionado $50 \mu \mathrm{L}$ de água RNase free em cada amostra da reação de síntese de cRNA, tornando o volume final da reação de 100 مoi adicionado $350 \mu \mathrm{L}$ do reagente cRNA Binding Buffer em cada amostra e misturamos por 3 segundos. Em seguida, foi adicionado $250 \mu \mathrm{L}$ de etanol (80\%) em cada amostra. Essa solução foi aplicada nas colunas de cRNA Cleanup Spincolocando em um tubo coletor de $2 \mathrm{~mL}$. A reação foi centrifugada em minicentrifuga por 15 segundos a $9000 \times \mathrm{g}$ e descartamos o filtrado. A coluna foi transferida para um novo tubo coletor, foi adicionado $500 \mu \mathrm{L}$ cRNA Wash Buffer, e foi centrifugado por 15 segundos a $9000 \times \mathrm{g}$ e o filtrado foi descartado. Em seguida, foi adicionado $500 \mu \mathrm{L}$ de etanol (80\%), e centrifugado por 15 segundos a $9000 \times \mathrm{g}$ e o filtrado foi descartado. Em seguida, com a tampa da coluna aberta a reação foi centrifugada em velocidade máxima (25000 x g) por 5 minutos. A coluna foi transferida para um novo tubo coletor e foi adicionado $15 \mu \mathrm{L}$ de água $R$ Nase-free diretamente na membrana da coluna. Reação foi centrifugada a velocidade máxima $(25.000 \times \mathrm{g})$ por 1 minuto. Eluimos pela segunda vez, colocando a solução eluida na mesma 
membrana da coluna e incubamos a temperatura ambiente por 5 minutos e centrifugamos por 1 minuto a velocidade máxima $(25.000$ x g).

A concentração de cRNA foi analisada utilizando o espectrofotômetro. A concentração mínima para o seguimento do protocolo foi entre $1,23 \mu \mathrm{g} / \mu \mathrm{L}$ e $1,53 \mu \mathrm{g} / \mu \mathrm{L}$.

\subsubsection{Síntese da $1^{\circ}$ fita de cDNA ( $2^{\circ}$ Ciclo)}

Foram adicionadas nas amostras de cRNA do último procedimento,

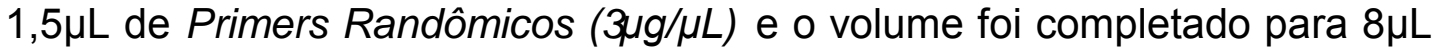
com água livre de RNase. Após, as amostras foram incubadas a $70^{\circ} \mathrm{C}$ por 5 minutos, a $25^{\circ} \mathrm{C}$ por 5 minutos e a $4^{\circ} \mathrm{C}$ por pelo menos 2 minutos. Enquanto as amostras estavam incubando um novo mix foi preparado.

\subsubsection{Síntese da $2^{\circ}$ fita de cDNA ( $2^{\circ}$ Ciclo)}

Foi preparado o Master Mix $2^{\circ}$ Ciclo / Síntese de cDNA $1^{\circ}$ Fita adicionando $4 \mu \mathrm{L}$ do $5 X 1^{\text {st }}$ Strand Buffer, $2 \mu \mathrm{L}$ de $\operatorname{DTT}(0,1 \mathrm{M}), 1,25 \mu \mathrm{L}$ $d N T P+d U T P(10 m M)$ e 4,75 $\mu \mathrm{L}$ da SuperScript // com um volume final de 12 $\mu \mathrm{L}$. Transferimos $12 \mu \mathrm{L}$ do Master Mix $2^{\circ}$ Ciclo / Síntese de cDNA $1^{\circ}$ Fitaao tubo da reação anterior, misturamos com cuidado e centrifugamos rapidamente. Incubamos a reação a $25^{\circ} \mathrm{C}$ por 10 minutos, $42^{\circ} \mathrm{C}$ por 90 minutos, $70^{\circ} \mathrm{C}$ por 10 minutos e $4^{\circ} \mathrm{C}$ por 2 minutos.

\subsubsection{Hidrólise do cRNA}

Para este procedimento utilizamos o Kit GeneChip ${ }^{\circledR}$ WT cDNA Synthesis. Primeiramente, adicionamos $1 \mu \mathrm{L}$ de RNAse $\mathrm{H}$ em cada amostra e incubamos a $37^{\circ} \mathrm{C}$ por 45 minutos, $95^{\circ} \mathrm{C}$ por 5 minutos e $4^{\circ} \mathrm{C}$ por 2 minutos. 


\subsubsection{Purificação de Fita única DNA}

Neste procedimento foi utilizado o kit GeneChip® Sample Cleanup Module. Adicionamos $80 \mu \mathrm{L}$ dágua livre de RNase em cada amostra, depois adicionamos $370 \mu \mathrm{L}$ de cDNA Binding Buffer, e misturamos por 3 segundos. Aplicamos toda a amostra (volume de aproximadamente $471 \mu \mathrm{L}$ ) na Spin Column com um tubo coletor de $2 \mathrm{~mL}$. Centrifugamos a $9.000 \times \mathrm{g}$ por 1 minuto. Descartamos o filtrado. Transferimos o cDNA Cleanup Spin Column para um novo tubo coletor de $2 \mathrm{~mL}$ e adicionamos $750 \mu \mathrm{L}$ de $c D N A$ Wash Buffer a coluna. Centrifugamos a $9.000 \times \mathrm{g}$ por 1 minuto e descartamos o filtrado. Abrimos a tampa do cDNA Cleanup Spin Columne centrifugamos a $16.000 \times \mathrm{g}$ por 7 minutos com as tampas abertas. Descartamos o filtrado e colocamos a coluna em um novo tubo de $1,5 \mathrm{~mL}$. Adicionamos $15 \mu \mathrm{L}$ do cDNA Elution Buffer diretamente na membrana da coluna e incubamos a temperatura ambiente por 1 minuto. Depois centrifugamos a 16.000 x g por 3 minutos. Repetimos o passo de eluição, adicionando $15 \mu \mathrm{LcDNA}$ Elution Bufferdiretamente na coluna da membrana e incubamos a temperatura ambiente por 1 minuto.Depois centrifugamos a $16.000 \times \mathrm{g}$ por 1 minuto. O volume final da fita única de DNA eluida foi de 28 $\mu \mathrm{L}$. Dosamos o rendimento no aparelho espectrofôtmetro, utilizando $2 \mu \mathrm{L}$ de amostra. A concentração foi entre $5,5 \mu \mathrm{g}$ total ou $220 \mathrm{ng} / \mu \mathrm{L}$ de fitaúnica de DNA.

\subsubsection{Fragmentação de Fita Única DNA}

Para este procedimento foi utilizado o Kit GeneChip® WT Terminal Labeling (cat. n900671, Affymetrix, Santa Clara, CA, EUA). Em novos tubos de $0,2 \mathrm{~mL}$ utilizamos $5,5 \mu \mathrm{g}$ da fitánica de DNA (volume variável) e água livre de RNase para um volume final de 31,2 $\mu \mathrm{L}$. Preparamos o Master Mix de Fragmentação utilizando, $10 \mu \mathrm{L}$ deágua livre de $\mathrm{RNa}$ se, $4,8 \mu \mathrm{L}$ de $10 X$ cDNA Fragmentation Buffer, 1,0 $\mu \mathrm{L}$ UDG $(10 \mathrm{U} / \mu \mathrm{L}), 1,0 \mu \mathrm{L}$ de APE $(1,000$

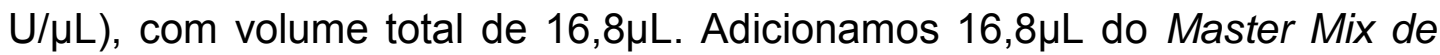
Fragmentação nas amostras. Misturamos e com cuidado, centrifugamos 
rapidamente. Incubamos a reação por 60 minutos a $37^{\circ} \mathrm{C}, 93^{\circ} \mathrm{C}$ por 2 minutos e $4^{\circ} \mathrm{C}$ por pelo menos 2 minutos, as amostras foram homogenizadas e transferimos $45 \mu \mathrm{L}$ da amostra em um novo tubo de 0,2 mL. Neste momento, realizamos um controle de qualidade, analisando no aparelho Bioanalyser para avaliar a fragmentação das amostras. Estas apresentavam entre 40 e 70 nt (nucleotídeos).

\subsubsection{Marcação e Fragmentação de Fita única DNA}

Para esta etapa utilizamos o kit GeneChip ${ }^{\circledR}$ WT Terminal Labeling. Preparamos os mix de marcação utilizando 1ฉL 5X TdT Buffer, $2 \mu \mathrm{L}$ de $T d T, 1 \mu \mathrm{L}$ de DNA Labeling Reagent ( $5 \mathrm{mM})$ e por fim, $45 \mu \mathrm{L}$ de DNA fita única fragmentado. As amostras foram homogenizadas e incubadas a $37^{\circ} \mathrm{C}$ por 60 minutos, $70^{\circ} \mathrm{C}$ por 10 minutos, $4^{\circ} \mathrm{C}$ por 2 minutos.

\subsubsection{Hibridização}

Utilizamos o kit GeneChip ${ }^{\circledR}$ WT Terminal Labeling para esta etapa. Três blocos de aquecimento são necessários $\left(65^{\circ} \mathrm{C}, \quad 99^{\circ} \mathrm{C}\right.$, $45^{\circ} \mathrm{C}$ ). Preparamos um mix de hibridização. Adicionamos 1,7 $\mu \mathrm{L}$ do reagente Control Oligonucleotide B2 (3nM), $5 \mu \mathrm{L}$ do 20X Eukaryotic Hibridization, 50 $\mu \mathrm{L} 2 X$ Hybridization Mix, $7 \mu \mathrm{L}$ de DMSO, 9,3 $\mu \mathrm{L}$ de água livre de RNase e 27 $\mu \mathrm{L}$ de DNA fitaúnica fragmentado. Após a homogeneização, as amostras foram incubadas a $99^{\circ} \mathrm{C}$ por 5 minutos e em seguida a $45^{\circ} \mathrm{C}$ por 5 minutos. Centrifugamos por 1 minuto na velocidade máxima (16.000 x g). Foi aplicado $80 \mu \mathrm{L}$ dessa solução no GeneChip ${ }^{\circledR}$. Colocamos o GeneChip ${ }^{\circledR}$ no forno de hibridização (Hybridization Oven 640, Affymetrix, P/N 800138 110V) à rotação de $60 \times$ g por 18 horas a $45^{\circ} \mathrm{C}$. 


\subsubsection{Lavagem e Marcação dos GeneChips ${ }^{\circledR}$}

Após esse período de incubação, as demais etapas foram realizadas no aparelho Fluidcs Station 400 ou 450/250, operado com o software GOCS/Microarray Suit. Os GeneChip ${ }^{\circledR}$ foram submetidos a 10 ciclos de lavagem a $25^{\circ} \mathrm{C}$ com tampão não estringente (6X SSPE, 0.01\% Tween-20) e 8 ciclos de lavagem a $50^{\circ} \mathrm{C}$ com tampão estringente (100 mM MES, $0.1 \mathrm{M}$ [Na+], 0.01\% Tween-20). Em seguida, os GeneChip®foram deixados por 10 minutos a $25^{\circ} \mathrm{C}$ em solução SAPE (Streptoavidin-Phycoerythrin), constituída de $600 \mu \mathrm{L}$ de Stain Buffer (2X); $48 \mu \mathrm{L}$ de SFB (50 mg/mL); SAPE(1 mg/mL) e $540 \mu \mathrm{L}$ de água deionizada. Após nova lavagem de 10 ciclos com tampão não estringente a $30^{\circ} \mathrm{C}$, os GeneChips $® f$ foram incubados por 10 minutos em solução contendo anticorpo (300 $\mu \mathrm{L}$ de Stain Buffer $2 X ; 24 \mu \mathrm{L}$ de BSA- (50 $\mathrm{mg} / \mathrm{mL}$ ); $6 \mu \mathrm{L}$ de Goat IgG Stock $10 \mathrm{mg} / \mathrm{mL}$; $3.6 \mu \mathrm{L}$ de anticorpo biotinilado $0.5 \mathrm{mg} / \mathrm{mL}$ e $266.4 \mu \mathrm{L}$ de água deionizada) e submetidos à segunda etapa de incubação em solução SAPE por 10 minutos e $25^{\circ} \mathrm{C}$. A lavagem final consistiu em 35 ciclos a $35^{\circ} \mathrm{C}$ utilizando tampão não estringente.

\subsubsection{Obtenção dos dados}

A captura das imagens correspondentes à intensidade de sinal da hibridização foi realizada pelo aparelho GeneChip ${ }^{\circledR}$ Scanner $7 G$, operado com o auxílio do softwareGeneChip ${ }^{\circledR}$ Command Console. O software Expression Console ${ }^{\mathrm{TM}}$ (Affymetrix) foi utilizado para a determinação da qualidade da hibridização.

\subsubsection{Análise da qualidade dos dados}

\subsubsection{Análise da Imagem}

Os GeneChips ${ }^{\circledR}$ foram escaneados (Affymetrix GeneChip ${ }^{\circledR}$ Scanner 3000) e os valores de intensidade de sinal resultante da hibridização foram 
detectados. Toda a área do chip foi inspecionada com o objetivo de identificar a presença de artefatos, como manchas ou riscos. Outros parâmetros foram verificados, tais como a hibridização do Oligo B2 que, além de servir como controle positivo da hibridização, é utilizado pelo software para localizar a "grade" que define a área de cada spot. Foram considerados chips de qualidade satisfatória aqueles que apresentaram o contorno, os cantos e o nome do chip visíveis, visto que essas são as principais regiões relacionadas à hibridização desse controle.

\subsubsection{Controles positivos}

A porcentagem de genes presentes para cada amostra deve incluir os denominados controles positivos, os quais também funcionam como parâmetros para a verificação da qualidade do ensaio. Dentre esses, temos os controles positivos de hibridização (BioB, BioC e BioD, Cre) e os de amplificação, que consistem em controles externos (Dap, Lys, Phe, Thr).

Controles de hibridização: além do Oligo B2, outras moléculas de RNA amplificado e biotinilado são adicionadas como uma mistura (20X Eukaryotic Hybridization Controls) nas amostras a serem hibridizadas, que correspondem aos genes BioC e BioD (E.coli) e Cre (bacteriófago P1). Todos eles devem estar sempre presentes, com sinais crescentes de intensidade de acordo com suas concentrações finais na mistura: BioC (5 pM) < BioD $(25$ pM $)<$ Cre $(100$ pM $)$.

Controles de amplificação externos: São moléculas de RNA correspondentes aos genes Dap, Lys, Phe, Thr (espécie B. subtilis) que, por serem adicionados durante o preparo das amostras, são utilizados para monitorar todo o processo de amplificação e marcação do RNA mensageiro. Devem ser considerados presentes em todas as amostras, com intensidades de sinal crescentes de acordo com sua concentração na solução: Lys<Phe<Thr<Dap. Da mesma forma que para os controles internos, a razão entre as intensidades de sinal dos probe sets que representam as regiões a 3' e 5' desses genes devem estar em torno de 3.0. 


\subsubsection{Análise dos dados de Microarrays}

As análises do perfil de expressão induzido pelo tratamento com DHA foram realizadas pela Doutora em Ciências pela Universidade de São Paulo (USP), com ênfase em Bioinformática, Daniele Yumi Sunaga da empresa Genotypics Assessoria e Consultoria em Genética LTDA.

\subsubsection{Pré-processamento dos dados}

Os valores de intensidade de sinal para cada probe set foi calculado pelo método RMA (Robust Multiarray Average), baseado em median polish, considerando apenas os valores de intensidade das sondas PM. ${ }^{[71]}$

\subsubsection{Classificação dos genes diferencialmente expressos}

O método SAM (Significance Analysis of Microarrays) ${ }^{[72]}$ pareado com permutação foi aplicado para a identificação dos genes diferencialmente expressos (DEGs), com p<0,05 corrigidos por FDR (False Discovery Rate) [73].

\subsubsection{Classificação funcional}

A análise funcional (in silico) foi feita com o programa IPA (Ingenuity Pathway Analysis, http://www.ingenuity.com/). Consideramos os parâmetros defaultMolecules per Network $=35$ e Networks per Analysis $=25$, que significa que foram definidas no máximo 25 redes biológicas hipotéticas com no máximo 35 genes cada. Estas redes são chamadas hipotéticas, pois são criadas a partir de informações da literatura. Diferente do conceito das vias canônicas, as redes são dinâmicas, ou seja, mudam de acordo com a relação de genes que está sendo analisada. Os genes são representados por nós e o relacionamento entre dois genes é representado por uma aresta. 
Todas as arestas são suportadas por, no mínimo, 1 referência da literatura ou informação de vias canônicas. Foi utilizado o banco de dados Ingenuity Expert Information e a nova opção Ingenuity Expert Assist Findings, na qual as informações disponíveis foram manualmente curadas e revisadas de publicações científicas.

\subsubsection{Realização do RT PCR em Tempo Real}

\subsubsection{Desenho dos primers}

A sequência FASTA obtida do banco do Nucleotide (http://www.ncbi.nlm.nih.gov/nucleotide/) foi utilizada para acessar a sequência genômica por meio da ferramenta BLAT (http://www.genome.ucsc.edu/cgi-bin/hgBlat), na qual os primers foram desenhados, seguindo os seguintes critérios:

1. Localização em éxons diferentes, o que possibilita reconhecer a amplificação de sequência genômica contaminante (Íntron extensor), o que minimiza a possibilidade de amplificação de possíveis sequências genômicas contaminantes;

2. Temperatura de anelamento dos primers em torno de $60^{\circ} \mathrm{C}$, calculada de acordo com o número de bases $\mathrm{G} / \mathrm{C}$ ou $\mathrm{A} / \mathrm{T}$ presentes em cada sequência. 
4. Resultados 


\subsection{Extração e Purificação do RNA total}

O primeiro passo determinante para o sucesso da técnica de microarray é a qualidade da integridade do RNA total extraído e purificado. As amostras de RNA total purificadas apresentaram níveis de pureza satisfatórios após a quantificação com relação 260/280 entre 1,9 e 2,0. As integridades das amostras foram determinadas pela análise do valor do RIN obtido para cada amostra. Amostras são consideradas de boa qualidade quando apresentam valores de RIN acima de 7. Em nosso estudo, os RNAs extraídos apresentaram ótima integridade, com valores de RIN variando entre 9 e 10, como exemplificado na Figura 4, que demonstra eletroferogramas das três linhagens, controle e tratada.

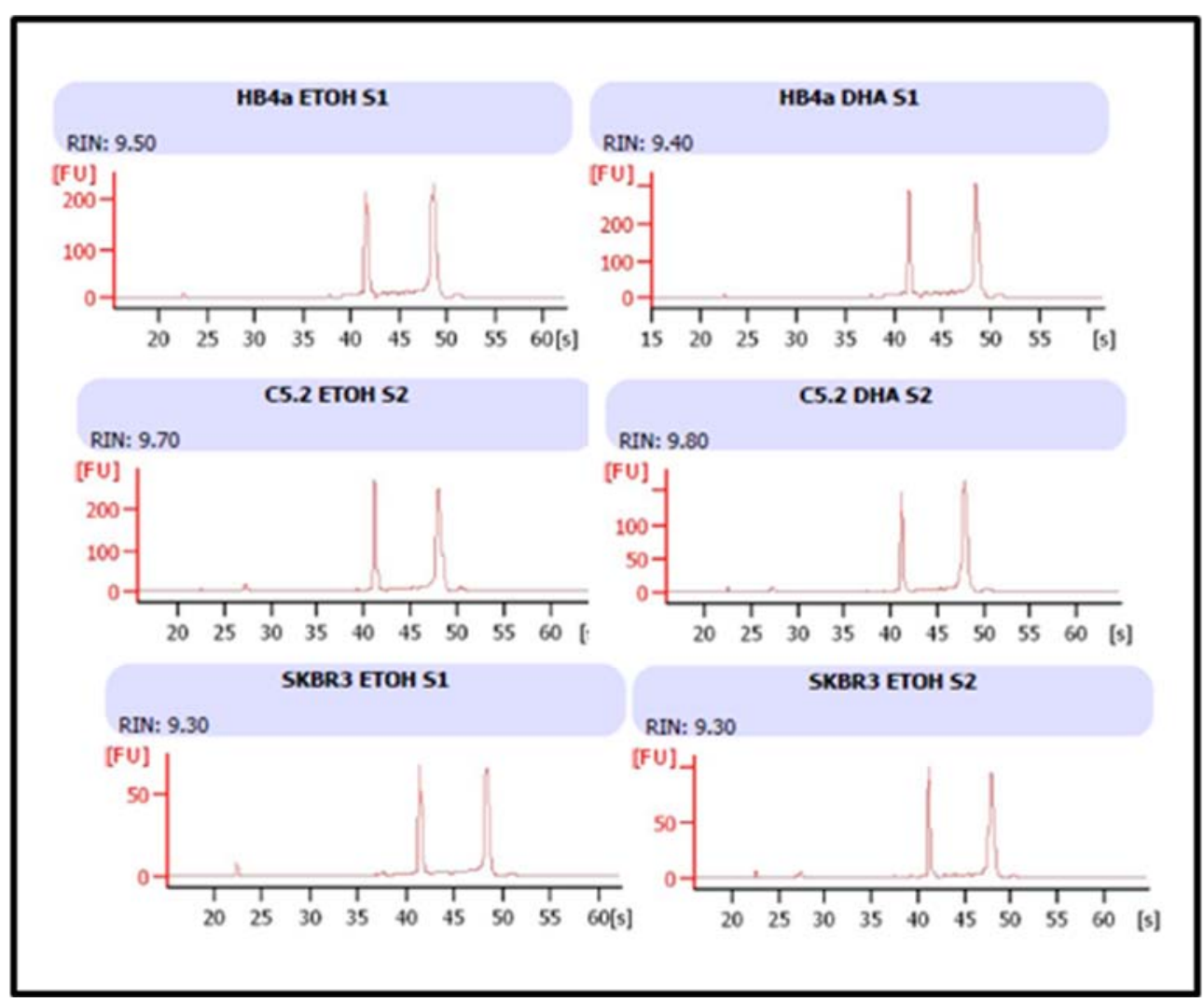

Figura 4: Análise da integridade do RNA total utilizando o Bioanalyser. Imagens de eletroferograma correspondentes a dois ensaios independentes (S1, semana 1 e S2, semana 2) , das três linhagens (HB4a, HB4aC5.2 (C5.2) e SKBR3), controle (ETOH) e tratada (DHA). RIN (RNA Integrity Number). [FU]:Fluorescência e [s]: segundos. 


\subsection{Análise da Qualidade dos Dados}

\subsubsection{Análise da Qualidade da Imagem dos Genechips ${ }^{\circledR}$}

A avaliação da qualidade da hibridização foi realizada pelo software Affymetrics (Expression Console ${ }^{\mathrm{TM}}$ Software Version 1.0). Os valores de intensidade de sinal resultante da hibridização com os Genechips ${ }^{\circledR}$ foram detectados utilizando o Affymetrix Genechips ${ }^{\circledR}$ Scanner 3000. Todas as áreas dos Genechips ${ }^{\circledR}$ foram inspecionadas, com o objetivo de identificar a presença de artefatos, tais como manchas ou riscos. Além disso, outros parâmetros foram verificados, tais como a hibridização do Oligo B2 que, além de servir como controle positivo da hibridização, é utilizado pelo software para localizar a "grade" que define a área de cada spot. Foram considerados Genechips ${ }^{\circledR}$ de qualidade satisfatória aqueles que apresentaram o contorno, os cantos e o nome visíveis (Figura 5), visto que essas são as principais regiões relacionadas à hibridização desse oligo.

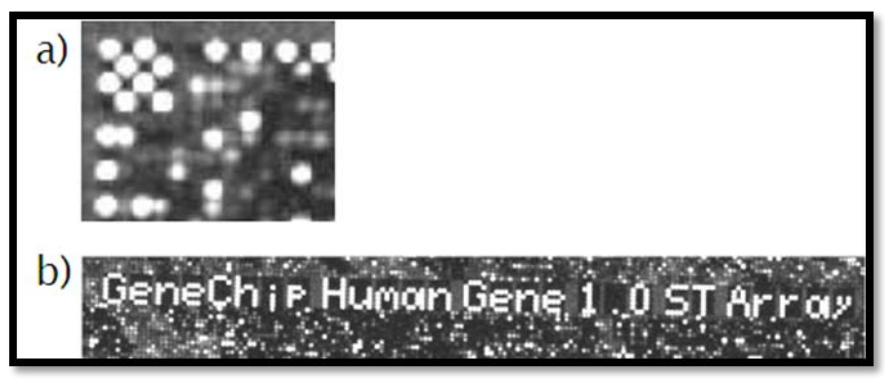

Figura 5: Imagens obtidas pelo Scanner 3000 após a hibridização das amostras. Cada quadrado representa uma região cell. a) Padrão alternado de hibridização do Oligo B2 em um dos cantos e nas bordas do chip;

b) Visualização do nome da lâmina também pela hibridização com esse oligo.

\subsubsection{Análise da Qualidade das Reações de Amplificação e hibridização}

O segundo passo determinante para o sucesso da técnica de microarray é a qualidade das reações de amplificação e hibridização, também realizada com o software Affymetrics (Expression Console ${ }^{\mathrm{TM}}$ Software Version 1.0). Durante a análise da qualidade das reações, valores de background mean (bgrd_mean) maiores que de perfect mean (pm_mean) 
indicam amostras de baixa qualidade. Em nossos experimentos, todas as amostras analisadas apresentaram valores de bgrd_mean menores que $p$ m_mean, indicando reações de boa qualidade. A Figura 6 demonstra a relação entre pm_mean e bgrd_mean.

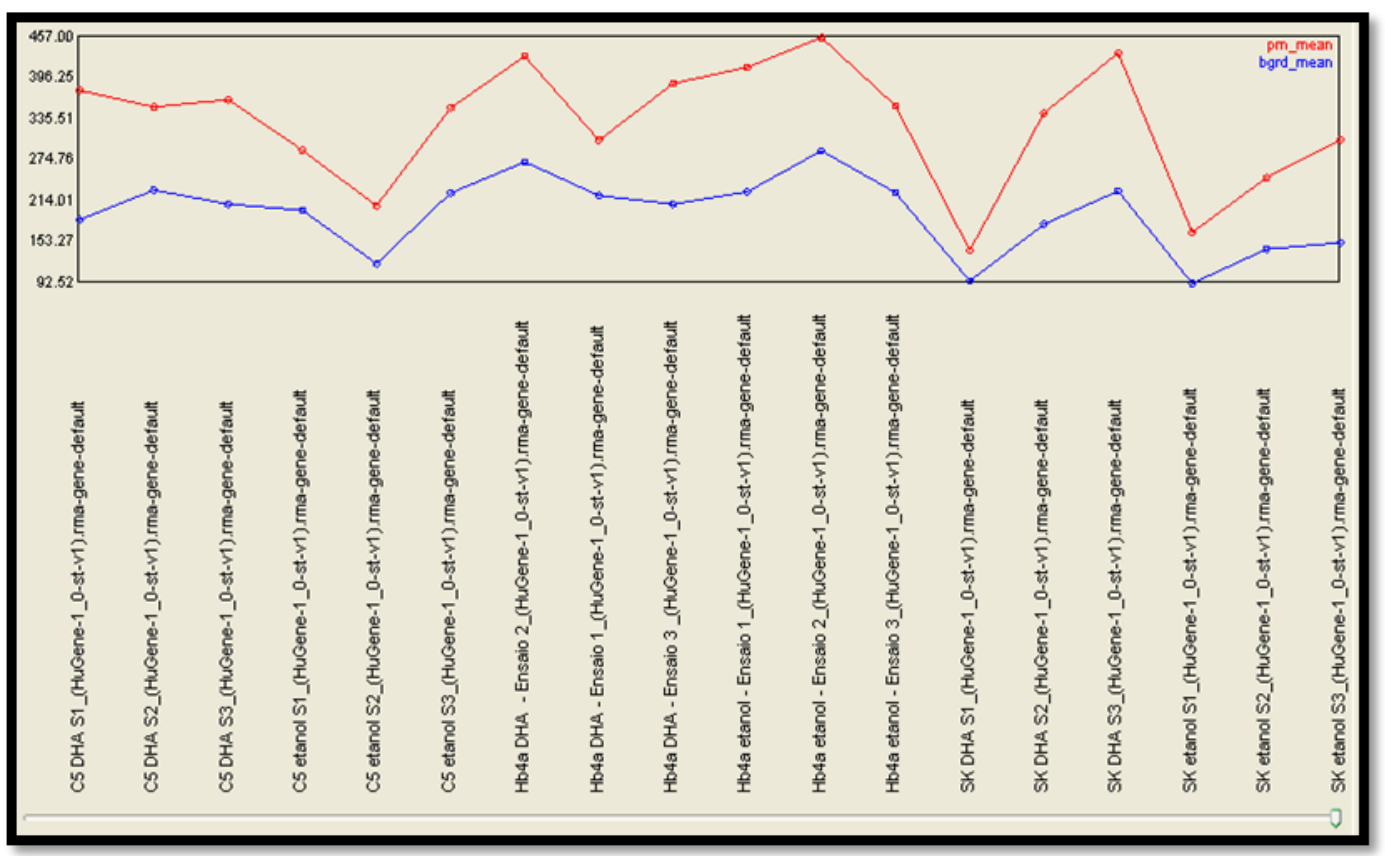

Figura 6: Genechips $₫$ demonstrados em três ensaios independentes (S1,S2 e S3). Valores de perfect mean (pm_mean) em vermelho e background mean (bgrd_mean) em azul. 
A relação "positivos versus negativos" (pos_vs_neg_auc) compara os sinais entre os controles positivos (medida de positivos verdadeiros) e negativos (medida de falsos positivos). Valores próximos de 1,0 indicam separação perfeita entre os controles. Valores abaixo ou iguais a 0,5 indicam não separação entre esses controles. Entre replicatas é aceitável uma diferença de 0,2. A Figura 7 ilustra os valores dessa relação obtidos nos Genechips®.

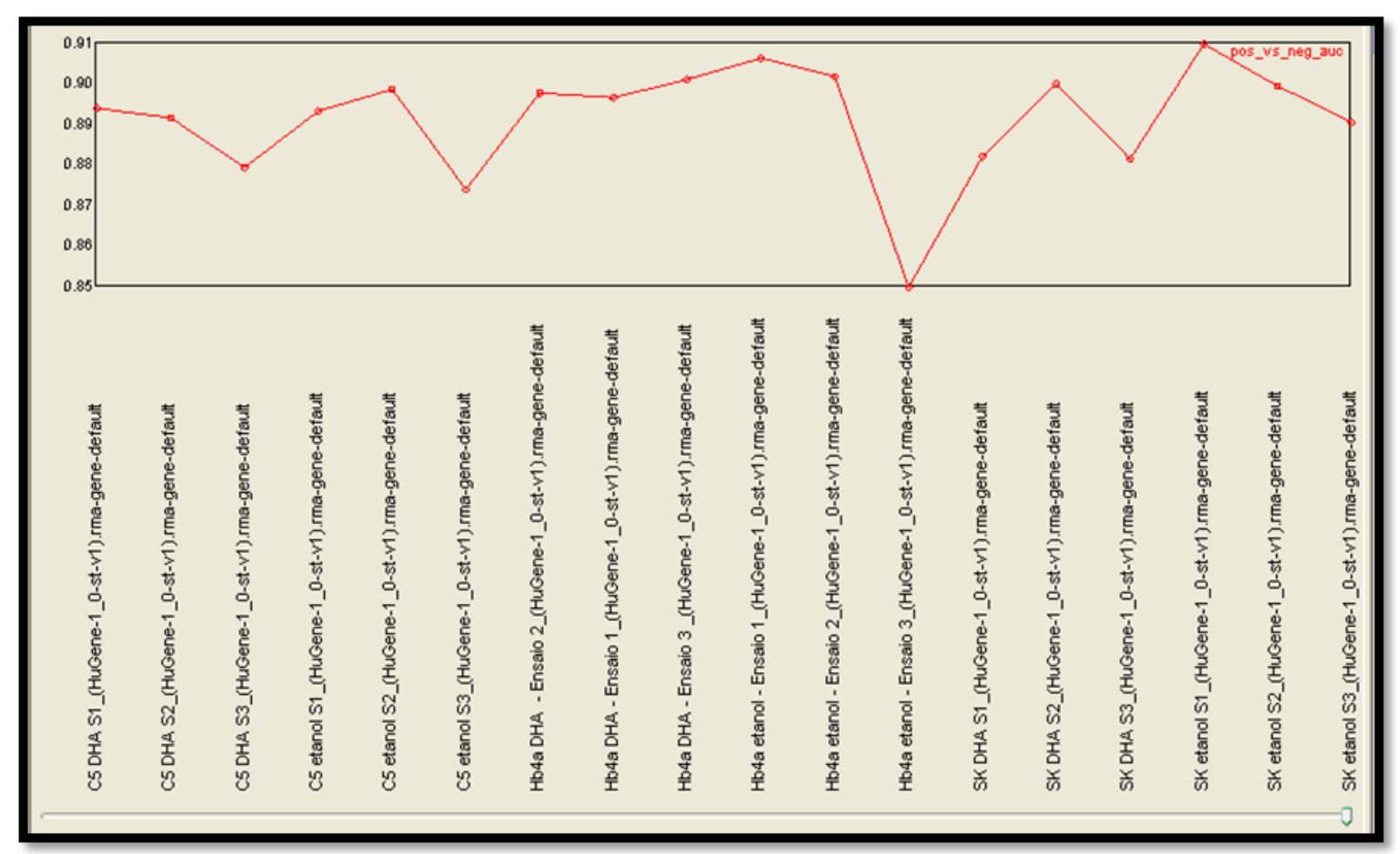

Figura 7: Genechips ${ }^{\circledR}$ demonstrados em três ensaios independentes. Valores de positivos versus negativos em vermelho. Observamos variação pequena entre os Genechips $₫$ sendo o menor valor 0,85 e o maior 0,91 . 
Os controles positivos de hibridização apresentaram intensidades de sinal a 3' na ordem estabelecida pelas concentrações diferentes: BioB 1.5 pM, BioC 5 pM, BioD 25 pM e Cre 100 pM segundo recomendações do fabricante. Assim, como demonstrado na Figura 8, todas as amostras apresentaram eficiências semelhantes de hibridização.

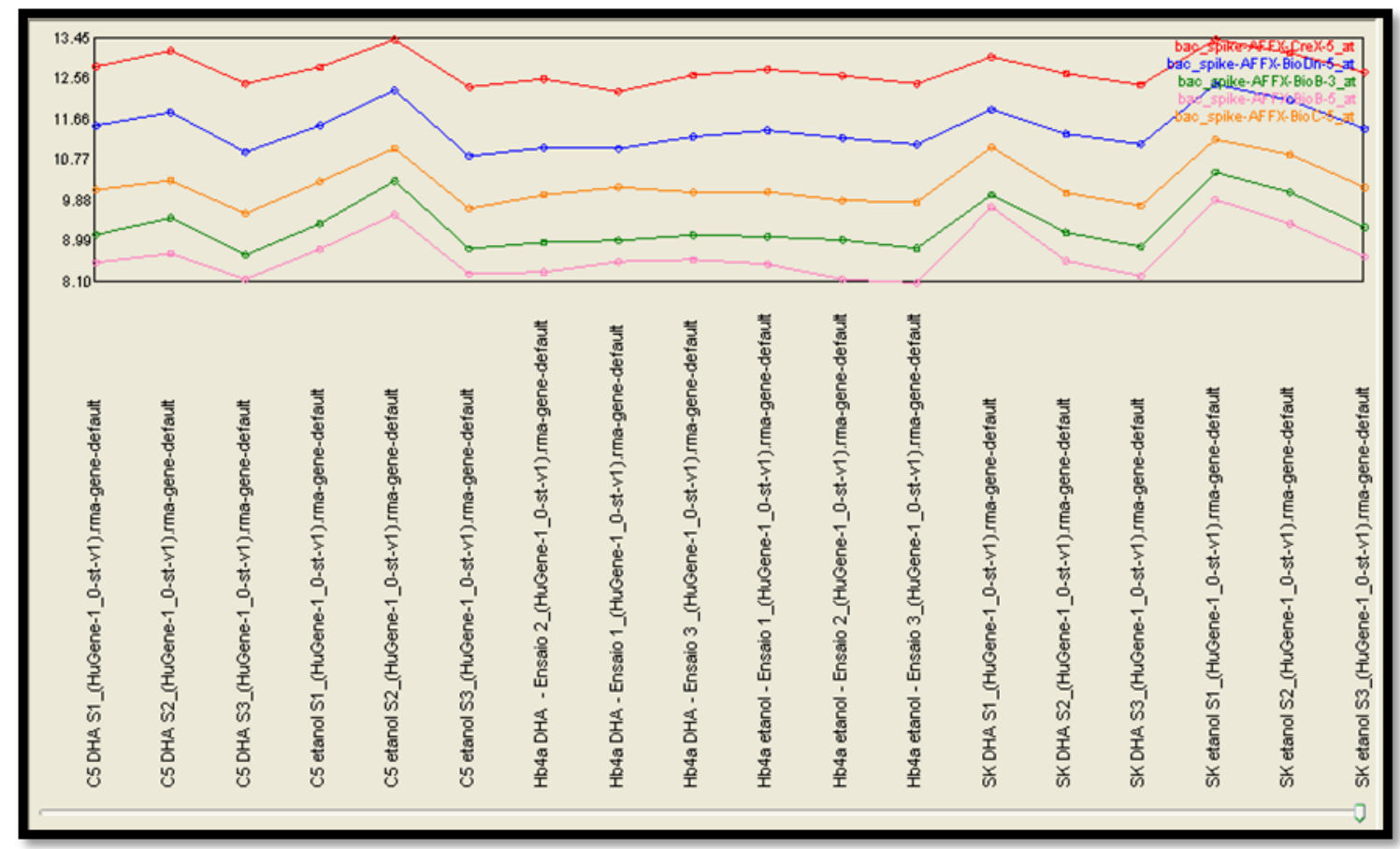

Figura 8: Controles positivos de hibridização. Semelhança entre os Genechips $®$ segundo a ordem $\mathrm{BioB}<\mathrm{BioC}<\mathrm{BioD}<\mathrm{Cre}$. 
Os controles de amplificação externos são formados por um conjunto de RNAs exógenos poliadenilados (Lys, Phe, Thr e Dap), os quais apresentam concentrações diferentes, Lys 1:100,000; Phe 1:50:000; Thr 1:25,000; Dap 1:7,500 e devem ser considerados presentes com valores de sinais crescentes na seguinte ordem: Lys, Phe, Thr e Dap. Estes controles apresentaram padrões normais na linhagem HB4a e padrão invertido entre o Phe e o Thr nas duas linhagens tumorigênicas, como podemos observar na Figura 9

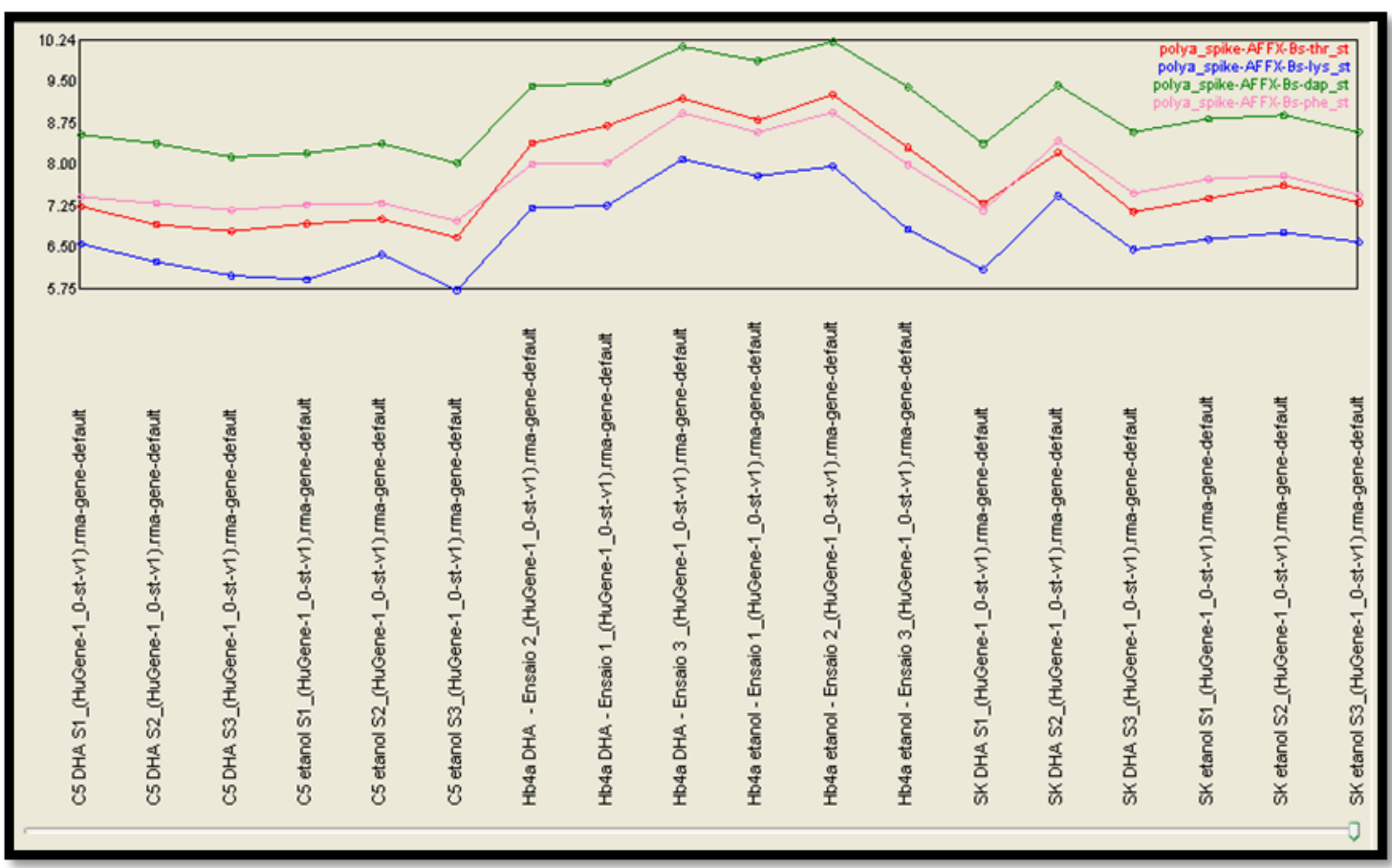

Figura 9: Controle de amplificação externo. Genechips ${ }^{\circledR}$ demonstrados em três ensaios independentes (S1,S2 e S3). Valores de Thr (vermelho), Lys (azul), Dap (verde), Phe (rosa). 


\subsubsection{Distribuição de Sinal}

O padrão de intensidade de sinal foi analisado por meio do Histograma de Sinal. Como observamos na Figura 10 a curva mantém o padrão de intensidade de sinal para todos os Genechips ${ }^{\circledR}$.

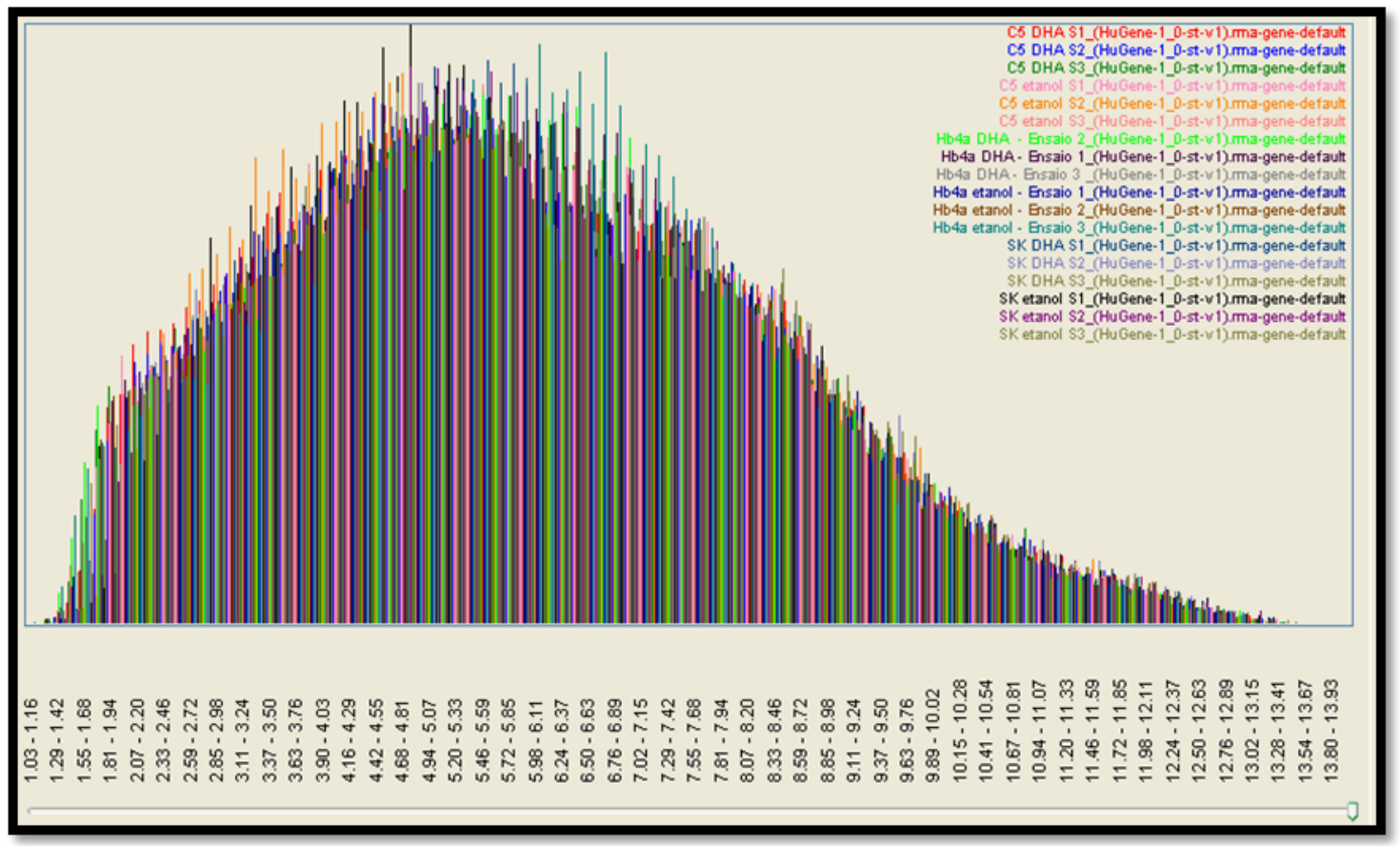

Figura 10: Histograma de Sinal. 
Além disso, a análise do Relative Signal Box Plot confirma a semelhança do padrão de intensidade entre os Genechips ${ }^{\circledR}$. As médias dos box plots devem ser zero ou muito próximas a zero. Como demonstrado na Figura 11 todos os box plots apresentaram essa média ao redor de 0 .

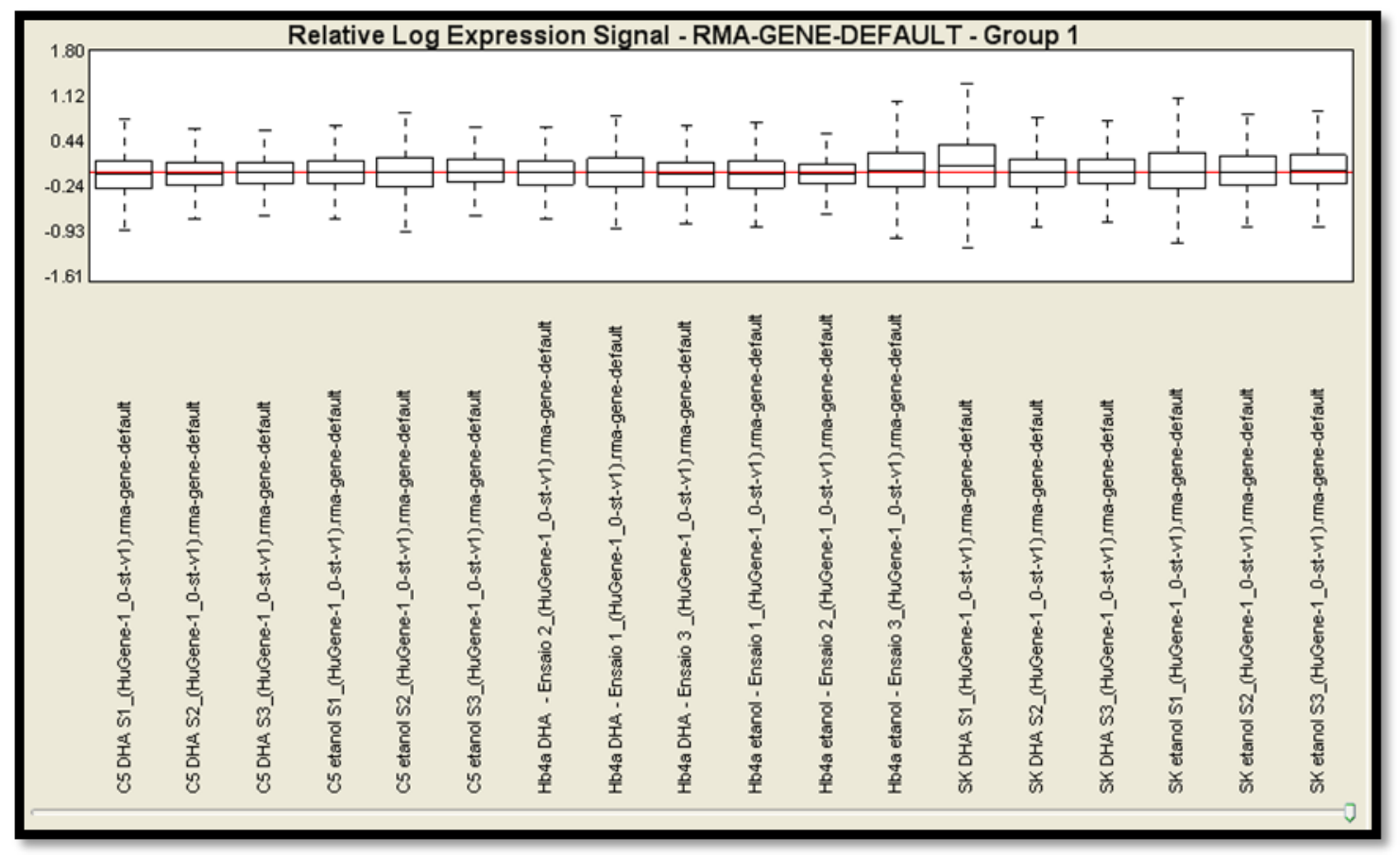

Figura 11: Box plots com média aproximada no valor 0 . Linhas verticais referentes ao nome de cada Genechips ${ }^{\circledR}$ das três linhagens.

\subsection{Descrição das análises de bioinformática}

Inicialmente o método SAM pareado foi aplicado para a identificação dos genes diferencialmente expressos (DEGs), com $p<0,05$ corrigidos por FDR. O resultado desta análise foi uma quantidade muito limitada de DEGs, impossibilitando posterior análise de agrupamento, busca por vias de sinalização e busca por categorias GO (Gene Ontology). Também aplicamos o método RankProd ${ }^{[74]}$ pareado com $p<0,05$ corrigido por FDR. Os dois métodos foram testados com diferentes valores para o filtro de dados de 
variância (sem filtro, 30\% e 50\%), mesmo assim, poucos DEGs foram selecionados, conforme descrito na Tabela 2 a seguir:

Tabela 2: Genes diferencialmente expressos (DEGs) utilizando método SAM e RankProd.

\begin{tabular}{lccc}
\hline \multicolumn{1}{c}{ Comparações } & $\begin{array}{c}\text { SAM } \\
\text { (DEGs) }\end{array}$ & $\begin{array}{c}\text { RankProd } \\
\text { (DEGs) }\end{array}$ & Comuns \\
\hline HB4a etanol vs HB4a DHA & 8 (filtro 50\%) & 20 (sem filtro) & 8 \\
C5.2 etanol vs C5.2 DHA & Todos hiper & 8 hiper e 12 hipo & 0 \\
SKBR3 etanol vs SKBR3 DHA & 2 (sem filtro) & 12 (sem filtro) & 2 \\
\hline
\end{tabular}

Legenda: hiper (hiper-expresso) e hipo(hipoexpressos)

Esta pequena quantidade de DEGs identificada por ambos os métodos indica que a diferença de expressão entre as amostras comparadas é sutil. Seriam necessárias mais amostras para que os métodos estatísticos pudessem identificar expressão alterada com significância. Por esta razão, foi definido um novo desenho de análise, em que as amostras foram replicadas de forma que cada uma das três amostras controle pudesse ser comparada com cada uma das três amostras tratadas. Desta forma, em vez de fazer três comparações pareadas, foi possível fazer nove comparações pareadas, conforme ilustrado na Figura 12. 


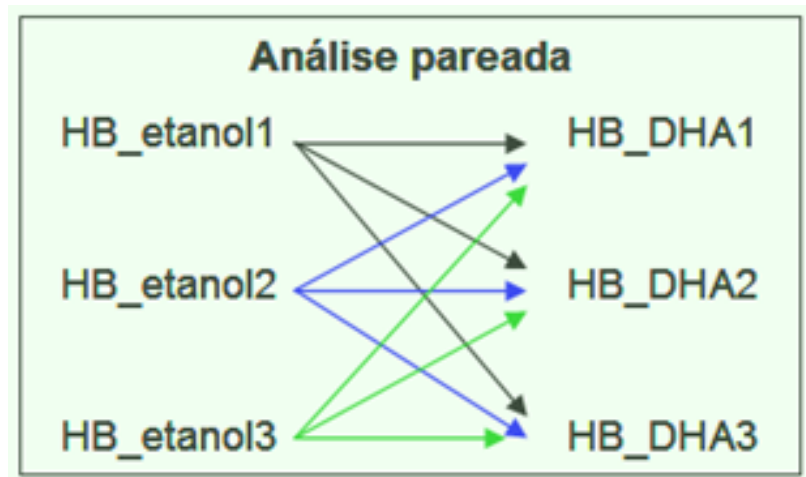

Figura 12: Novo desenho de análise estatística com análise pareada e com permutação.

Com este novo desenho de análise foi possível aumentar o poder estatístico do método SAM para a identificação dos DEGs, com valor de $p$ $<0,01$ corrigidos por FDR. Os resultados estão descritos na Tabela 3 a seguir:

Tabela 3: Genes diferencialmente expressos (DEGs) utilizando método SAM com análise pareada e com permutação.

\begin{tabular}{cc}
\hline Comparações & DEGs (SAM) \\
\hline HB etanol vs HB DHA & 174 \\
C5 etanol vs C5 DHA & $(136$ hiper e 38 hipo) \\
& 208 \\
SKBR3 etanol vs SKBR3 DHA & (32 hiper e 176 hipo) \\
\hline Legenda: hiper (hiper-expresso) e hipo(hipoexpressos)
\end{tabular}




\subsection{Análises dos genes diferencialmente expressos (DEGs)}

A partir das listas de DEGs de cada linhagem, começamos a busca pelos genes de interesse, ou seja, os genes modulados pelo DHA e que poderiam apresentar alguma função importante em relação à tumorigênese da mama. Primeiramente, os genes sem anotação (genes que já foram sequenciados, mas ainda não apresentam função definida) foram removidos. Após essa primeira triagem, a função de cada um dos genes foi avaliada no banco de dados do NCBI (National Center for Biotechnology Information) para genes (www.ncbi.nlm.nih.gov/gene). Assim, os grupos de genes com funções ou localizações celulares semelhantes foram categorizados. Como demonstrado na Tabela 4 para linhagem HB4a, Tabela 5 linhagem Hb4aC5.2 e Tabela 6 linhagem SKBR3.

Tabela 4: DEGs pré selecionados na linhagem HB4a

\begin{tabular}{|c|c|}
\hline Categoria & DEGS ( $\uparrow$ hiper-expressos ou $\downarrow$ hipoexpressos) \\
\hline \multirow{3}{*}{ Adesão Celular } & 个DSG3 $\uparrow C L D N 1 ~ \uparrow I T G A 2 ~ \uparrow S D C 1 \uparrow C A 12 \uparrow M Y L K \uparrow E C M 2$ \\
\hline & $\uparrow L T B P 1 \uparrow N T N 4 \uparrow T U B A 4 A \uparrow D S C 3 \uparrow C D 36 \uparrow C D 68$ \\
\hline & $\uparrow$ TIMP3 $\uparrow$ CEACAM $\downarrow$ ADAM21 \\
\hline \multirow{3}{*}{ Metabolismo Lipídico } & $\uparrow P D K 4 \uparrow C P T 1 A \uparrow A N G P T L 4 \uparrow A P O D \uparrow V L D L R$ \\
\hline & $\uparrow A C A D V L \uparrow R E T S A T \uparrow U G T 2 B 28 \uparrow O L A H ~ \uparrow S T O M$ \\
\hline & $\uparrow H M G C S 2 \uparrow E C H 1 \uparrow S 1 P R 3$ \\
\hline \multirow{2}{*}{ Diferenciação celular } & $\uparrow K R T 6 C \uparrow K R T 6 A \uparrow K R T 6 B \uparrow P L I N 2 \uparrow S 100 A 6 \uparrow S 100 A 2$ \\
\hline & $\uparrow I V L \uparrow C R Y A B$ \\
\hline Supressores de tumor & $\uparrow L O X \uparrow C L C A 2 \uparrow F A B P 3 \uparrow S E R P I N B 5 \uparrow N U P R 1 \uparrow A B L I M 1$ \\
\hline \multirow{2}{*}{ Transporte celular } & $\uparrow F X Y D 3 \uparrow S L C 3 A 2 \uparrow S L C 7 A 8 \uparrow S L C 7 A 11 \uparrow S L C 25 A 30$ \\
\hline & $\uparrow S L C 38 A 4 \uparrow S L C 25 A 20 \uparrow S L C 31 A 2$ \\
\hline \multirow{2}{*}{ Hipoexpressos } & $\downarrow$ FANCD2 $\downarrow$ CDC25C $\downarrow$ MKI67 $\downarrow$ FOXM1 $\downarrow$ KIF2 $\downarrow$ SRRT \\
\hline & $\downarrow$ SPAG5 $\downarrow$ RUNX2 $\downarrow$ KIF14 \\
\hline Oxidação e Redução & $\uparrow \mathrm{CAT} \uparrow \mathrm{AOX} 1 \uparrow \mathrm{HMOX} 1$ \\
\hline Sinalização Celular & $\begin{array}{l}\uparrow \mathrm{GRB} 10 \uparrow \mathrm{GPR} 87 \uparrow \mathrm{TFDP} 3 \uparrow \mathrm{KFL} 11 \uparrow \mathrm{KFL} 4 \uparrow \mathrm{RAB} 30 \\
\uparrow \mathrm{GCOM} 1\end{array}$ \\
\hline
\end{tabular}


Tabela 5: DEGs pré selecionados na linhagem HB4aC5.2

\begin{tabular}{|c|c|}
\hline Categoria & DEGS ( $\uparrow$ hiper-expressos ou $\downarrow$ hipoexpressos) \\
\hline $\begin{array}{l}\text { Invasão e } \\
\text { Metástase }\end{array}$ & $\uparrow$ SERPINF1 $\downarrow$ ANGPTL $1 \downarrow$ MMP26 $\downarrow$ S1PR $1 \downarrow$ SERPINI2 \\
\hline Transporte Celular & $\begin{array}{l}\downarrow S L C 25 A 31 \downarrow S L C 35 F 1 \downarrow K C N I P 1 \downarrow K C N H 8 \downarrow S L C 14 A 2 \\
\downarrow S L C 22 A 11 \\
\downarrow R I C 3 \downarrow C X C R 2 \downarrow G R M 8 \uparrow A N K R D 42 \downarrow A D O R A 1 \downarrow G P R 78\end{array}$ \\
\hline Membrana & $\downarrow$ TPTE $\downarrow$ RGS1 $\downarrow$ LYPLA2 $\downarrow$ SAG $\uparrow$ TBC1D2B $\downarrow$ TACR2 \\
\hline Plasmática & $\begin{array}{l}\downarrow \text { MCOLN3 } \downarrow \text { OR56A3 } \downarrow \text { OR7E13P } \downarrow \text { OR4C45 } \downarrow \text { GPR85 } \\
\downarrow \text { TMEM88 } \downarrow \text { PF4 } \downarrow \text { PCDH8 } \downarrow \text { AQP5 } \downarrow \text { ANKRD30B } \downarrow \text { NPTXR }\end{array}$ \\
\hline $\begin{array}{l}\text { Metabolismo } \\
\text { Lipídico }\end{array}$ & $\downarrow$ GDF3 $\downarrow$ ADRB3 $\downarrow$ NPY $\downarrow$ LIPN $\downarrow$ APOC 2 \\
\hline Sistema Imune & $\begin{array}{l}\downarrow \text { TARP } \uparrow \text { CDRT1 } \downarrow \text { SERPINI } 2 \downarrow D E F B 110 \downarrow \text { ENTPD } 1 \downarrow \text { GBP7 } \\
\downarrow \text { CDC14C } \downarrow \text { CD48 } \downarrow \text { NLRP } 7 \downarrow \text { HLA-DRA }\end{array}$ \\
\hline $\begin{array}{l}\text { Proteína Dedos de } \\
\text { Zinco }\end{array}$ & $\downarrow$ ZNF679 $\downarrow$ ZNF491 $\uparrow Z N F 528 ~ \uparrow Z N F 445 \uparrow Z N F 239 \downarrow$ TRIM55 \\
\hline Múltiplas funções & $\begin{array}{l}\downarrow \text { LDHAL6B } \downarrow \text { CSN2 } \downarrow \text { NAT8B } \downarrow \text { HOXD4 } \uparrow \text { CP } \downarrow \text { PCDH8 } \\
\downarrow \text { GCAT } \downarrow R B L 1 \downarrow \text { LRRC3B } \downarrow \text { DPEP } 1\end{array}$ \\
\hline
\end{tabular}

Tabela 6: DEGs pré selecionados na linhagem SKBR-3

\begin{tabular}{ll}
\hline Categoria & DEGS $\uparrow$ hiper-expressos ou $\downarrow$ hipoexpressos) \\
\hline Adesão Celular & $\downarrow$ ADAM23 $\downarrow$ PARP9 $\downarrow$ FAM38A $\uparrow$ AOC3 $\uparrow$ CLEC5A \\
& $\downarrow$ GJA10 \\
Metabolismo Lipídico & $\downarrow$ LDLR $\downarrow$ DHCR7 $\downarrow$ SC4MOL $\downarrow$ INSIG1 $\downarrow$ DDX60L \\
& $\downarrow$ AKR1D1 $\downarrow$ THRSP $\uparrow$ PDK4 $\downarrow$ SCD \\
Transporte Celular & $\downarrow$ SLCO1A2 $\downarrow$ SLC10A1 $\downarrow$ KCNJ1 $\downarrow$ SLC36A3 \\
& $\uparrow$ KCNV1 \\
Múltiplas Funções & $\uparrow$ TREX2 $\uparrow$ PTPRZ1 $\downarrow R T D R 1 \downarrow P T R H 2 \uparrow G S T A 1$ \\
Membrana Plasmática & $\downarrow$ NDUFA11 COXXA2 $\uparrow M A G E B 17$ \\
Mecanismos Epigenéticos & $\downarrow$ HIT1H2BJ $\downarrow$ N6AMT1 \\
\hline
\end{tabular}




\subsection{Análise Funcional dos DEGs}

A análise funcional dos DEGs (in silico) foi feita com o programa IPA (Ingenuity Pathway Analysis, http://www.ingenuity.com/).

A Figura 13 demonstra um exemplo de rede de ligações entre os DEGs na linhagem celular HB4a. Nas setas pontilhadas verifica-se a ligação indireta entre o gene CD36 (CD36 molecule-thrombospondin receptor) e o gene SDC1(syndecan 1), ambos hiperexpressos na linhagem HB4a após o tratamento.

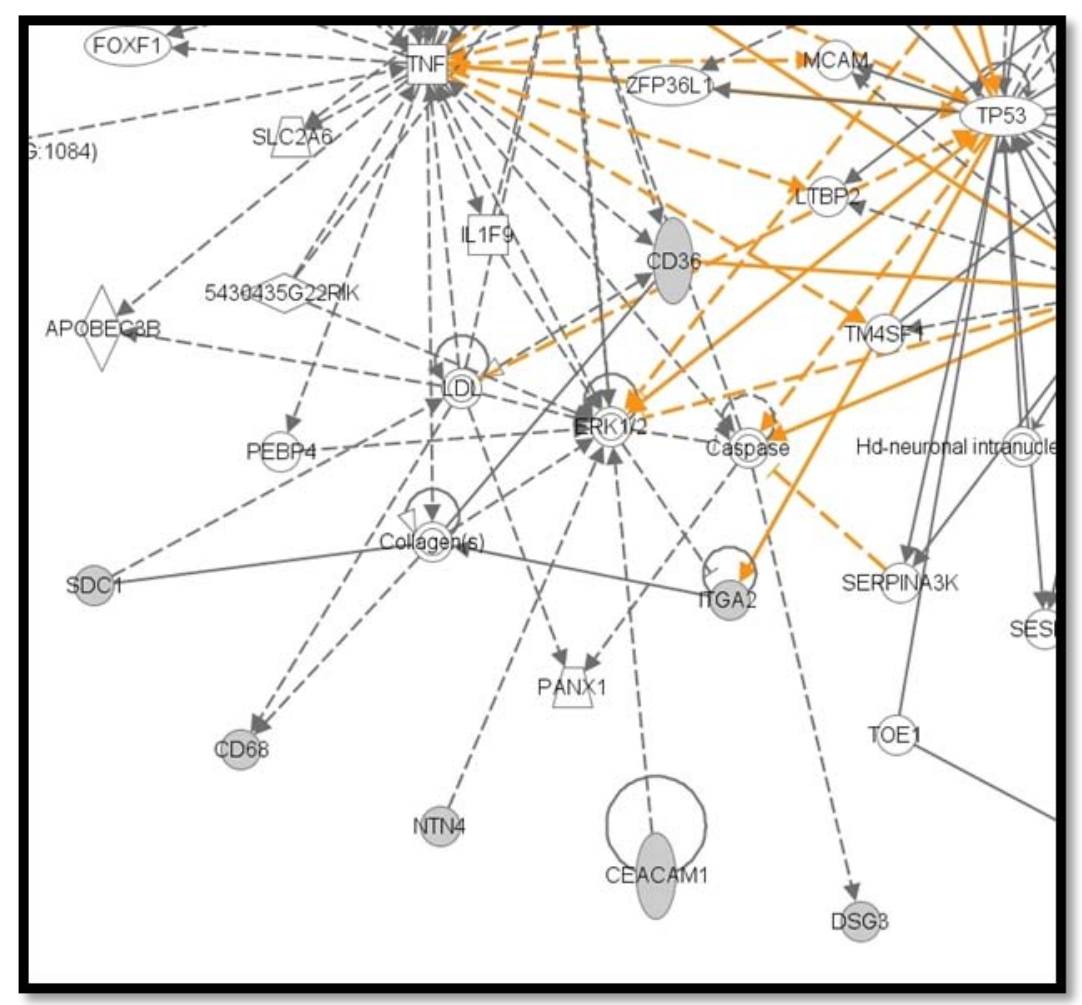

Figura 13: Rede de ligações gênicas na linhagem HB4a. Genes preenchidos com a cor cinza são diferencialmente expressos nessa linhagem após o tratamento com DHA. 
Entre os DEGs envolvidos com o metabolismo lipídico encontrados na linhagem HB4a após o tratamento com DHA, dois deles podem ser visualizados na Figura 14. O gene PDK4 (pyruvate dehydrogenase kinase, isozyme 4) e o ANGPTL4 (angiopoietin-like 4) apresentam ligações diretas com o gene PPARG (peroxisome proliferator-activated receptor gamma).

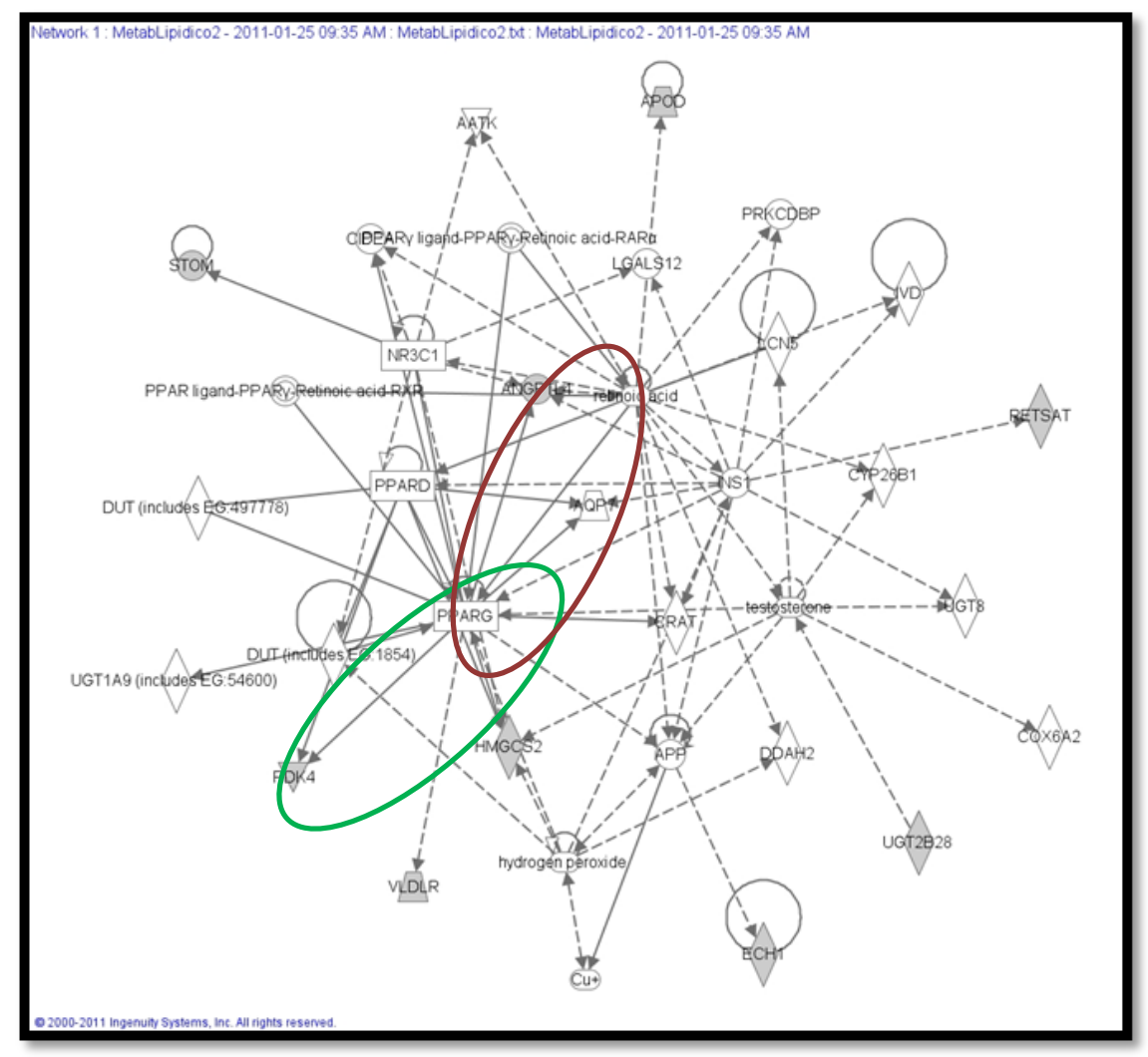

Figura 14: Rede de ligações gênicas na linhagem HB4a.Circulado em verde observamos a ligação do PPARG com PDK4. Em vermelho a ligação do mesmo fator transcricional com ANGPTL4. 
Adicionalmente, na linhagem HB4a, foram observados outros genes envolvidos com o metabolismo lipídico, como o SLC25A20(solute carrier family 25 (carnitine/acylcarnitine translocase- member 20) que codifica uma proteína carreadora de soluto envolvida na oxidação de ácidos graxos. Este gene está ligado diretamente como o fator transcricional PPARA (peroxisome proliferator-activated receptor alpha), demonstrado na Figura 15.

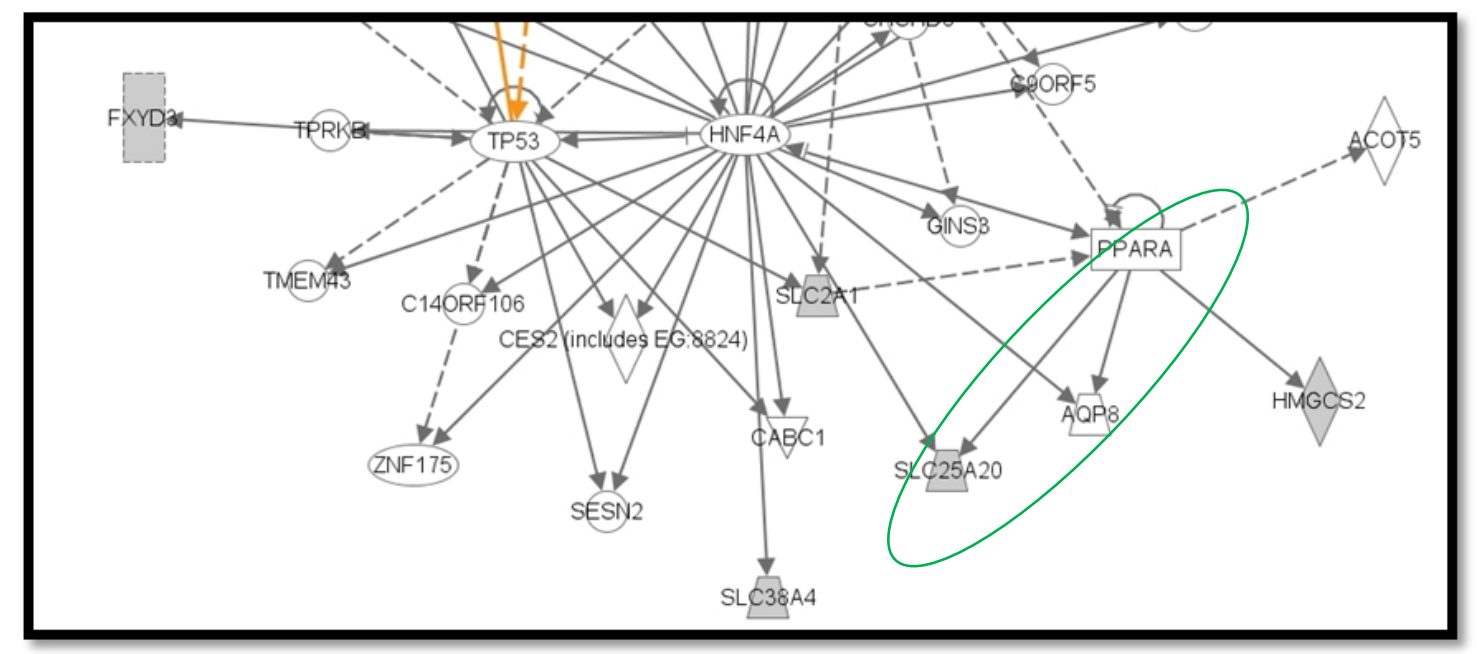

Figura 15: Rede de ligações gênicas na linhagem HB4a.Circulado em verde a ligação direta do PPARA com SLC25A20. 
$\mathrm{Na}$ Figura 16, observa-se outros DEGs da linhagem HB4a após o tratamento com DHA, como o FABP3 (fatty acid binding protein 3, muscle and heart /mammary-derived growth inhibitor) e o PLIN2(perilipin 2). Estes também demonstram envolvimento com os fatores de transcrição PPARD e PPARG. Alguns genes já descritos acima como o CD36, ANGPTL4 também apresentam ligações com estes fatores transcricionais.

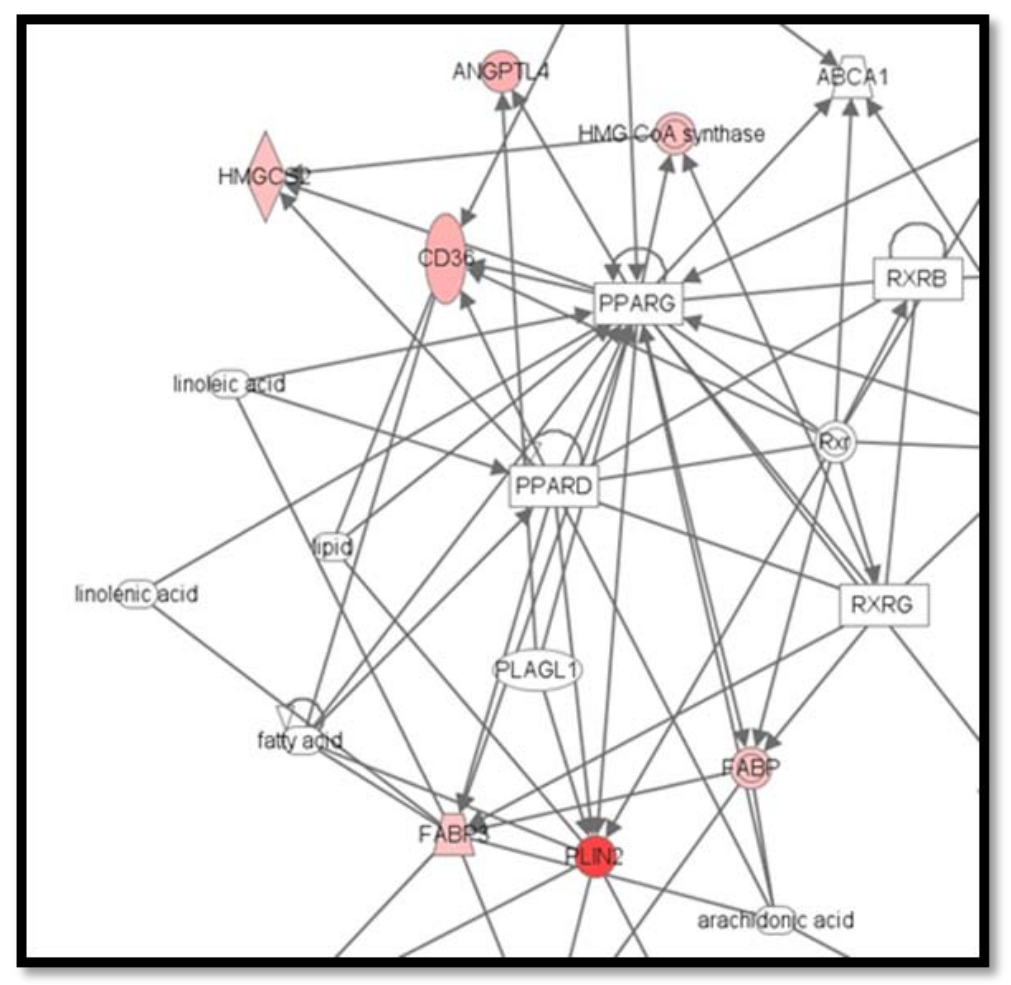

Figura 16: Rede de ligações gênicas na linhagem HB4a. DEGs hiperexpressos (preenchidos na cor vermelha) e envolvidos com PPARD e PPARG. 
Verificou-se a relação entre 0 gene CPT1A(carnitine palmitoyltransferase 1A-liver) com o gene CD36 já descrito anteriormente, ambos DEGs da linhagem HB4a e hiperexpressos após o tratamento, essa ligação pode ser observada na Figura 17. Adicionalmente, nesta rede de interação gênica, observou-se o envolvimento do gene SERPINB5(serpin peptidase inhibitor, clade B lovalbumin- member 5) com o gene SDC1 também descrito anteriormente e ambos hiperexpressos após o tratamento.

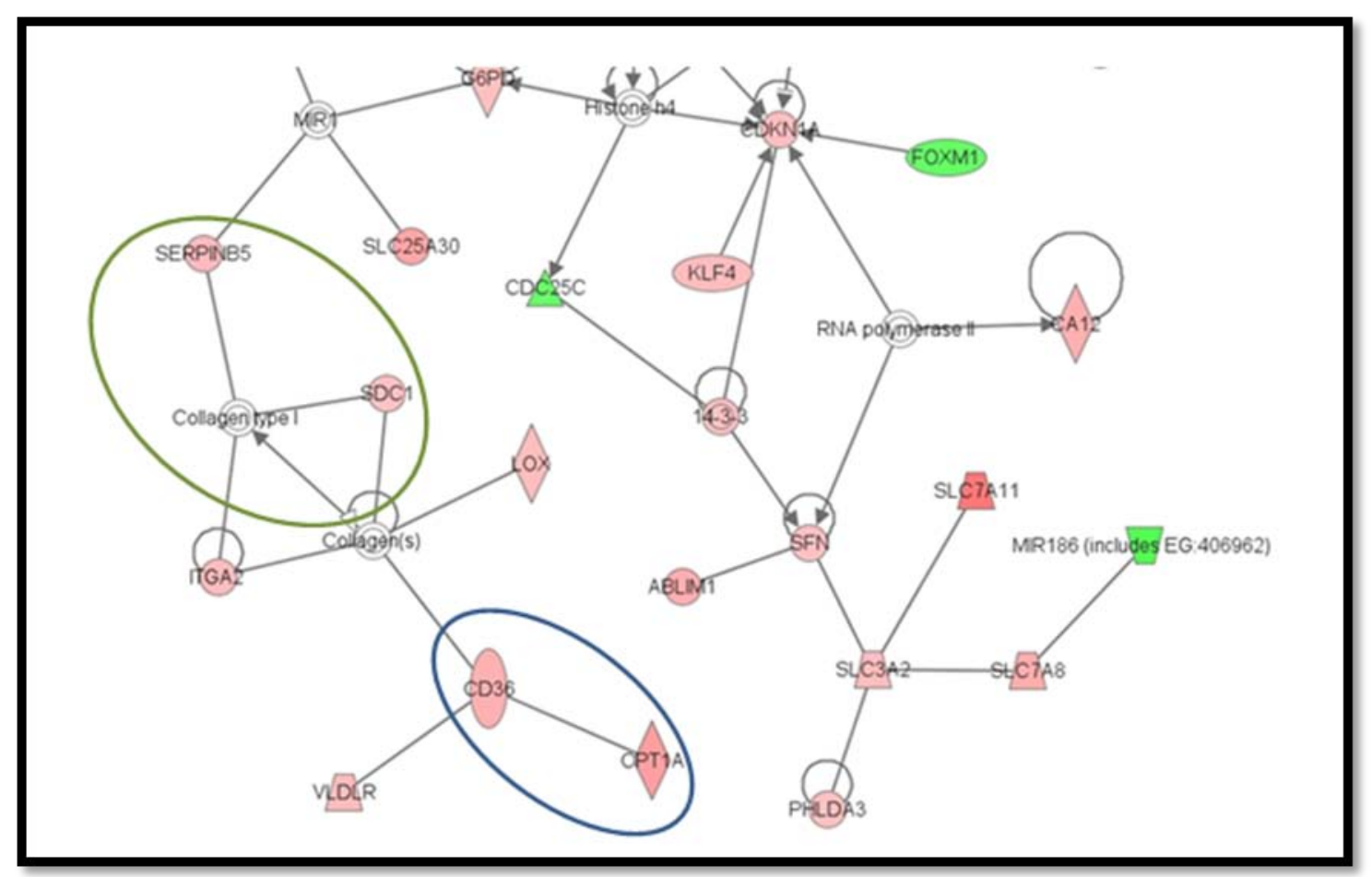

Figura 17: Rede de ligações gênicas na linhagem HB4a. DEGs hiperexpressos (preenchidos na cor vermelha). Envolvimento do gene SERPINB5 com SDC1 circulado em verde e ligação direta do CD36 com CPT1A circulado em azul. 
$\mathrm{Na}$ linhagem Hb4aC5.2 foi analisado as redes de interações gênicas com os DEGs após o tratamento com DHA. A Figura 18 demonstra ligações indiretas de três genes diferencialmente expressos, ANGPTL1(angiopoietinlike 1), S1PR1(sphingosine-1-phosphate receptor 1), CXCR2 (chemokine (C$X-C$ motif) receptor 2), com duas proteínas importantes para a sobrevivência e proliferação dessa linhagem, AKT (v-akt murine thymoma viral oncogene homolog 1) e ERK (mitogen-activated protein kinase 1) ${ }^{[7]}$.

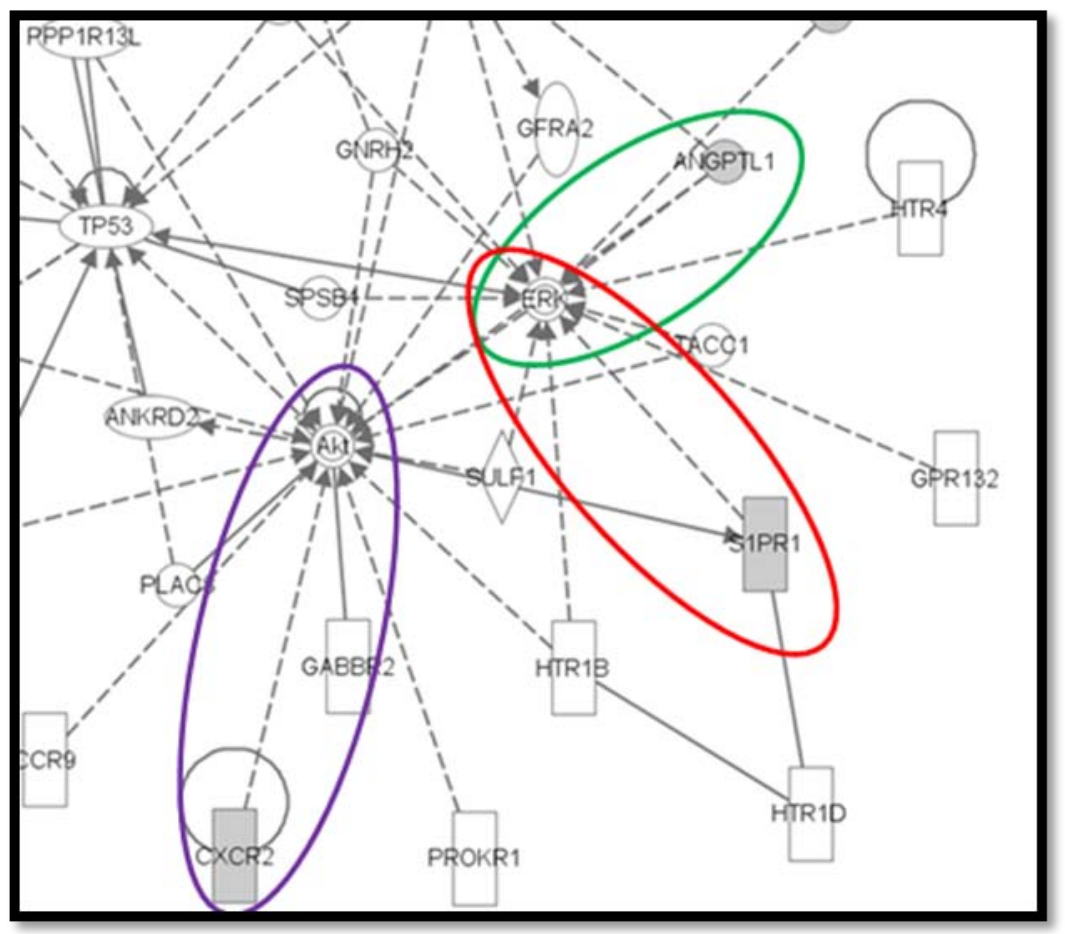

Figura 18: Rede de ligações gênicas na linhagem Hb4aC5.2.Circulado em verde observamos a ligação do ANGPTL1(angiopoietin-like 1) com ERK (mitogen-activated protein kinase 1). Circulado em vermelho, a ligação indireta entre S1PR1(sphingosine-1-phosphate receptor 1) e ERK.Em roxo, observamos a ligação indireta entre o gene CXCR2 (chemokine (C-X-C motif) receptor 2) com AKT (v-akt murine thymoma viral oncogene homolog 1). 
Adicionalmente na linhagem HB4aC5.2, verificou-se alguns genes envolvidos com o sistema imunológico. O genes CP (ceruloplasmin ferroxidase) hiperexpresso após o tratamento e o RBL1(retinoblastoma-like 1 -p107) hipoexpressos após o tratamento, demonstram ligação indireta com o TNF(tumor necrosis factor) como observado na Figura 19.

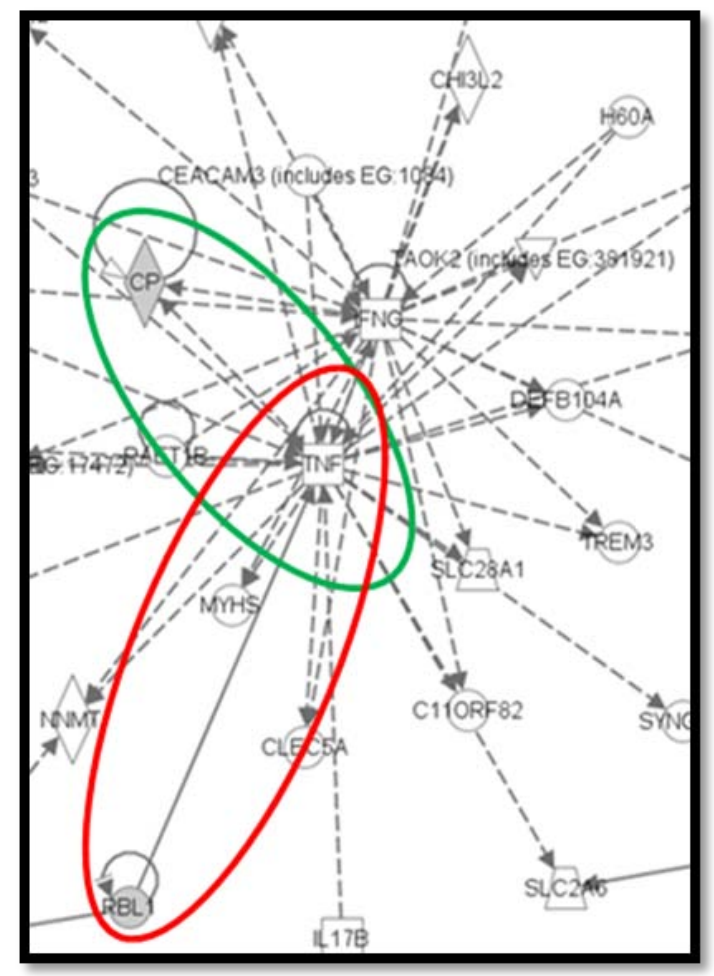

Figura 19: Rede de ligações gênicas na linhagem HB4aC5.2.Circulado em verde observamos a ligação do $C P$ com $T N F$. Em vermelho a ligação do mesmo gene com o gene RBL1. 
Observa-se na Figura 20 outra rede de interação gênica envolvendo o gene CP com outro gene hiperexpresso após o tratamento, SERPINF1(serpin peptidase inhibitor, clade F-alpha-2 antiplasmin, pigment epithelium derived factor, member 1).

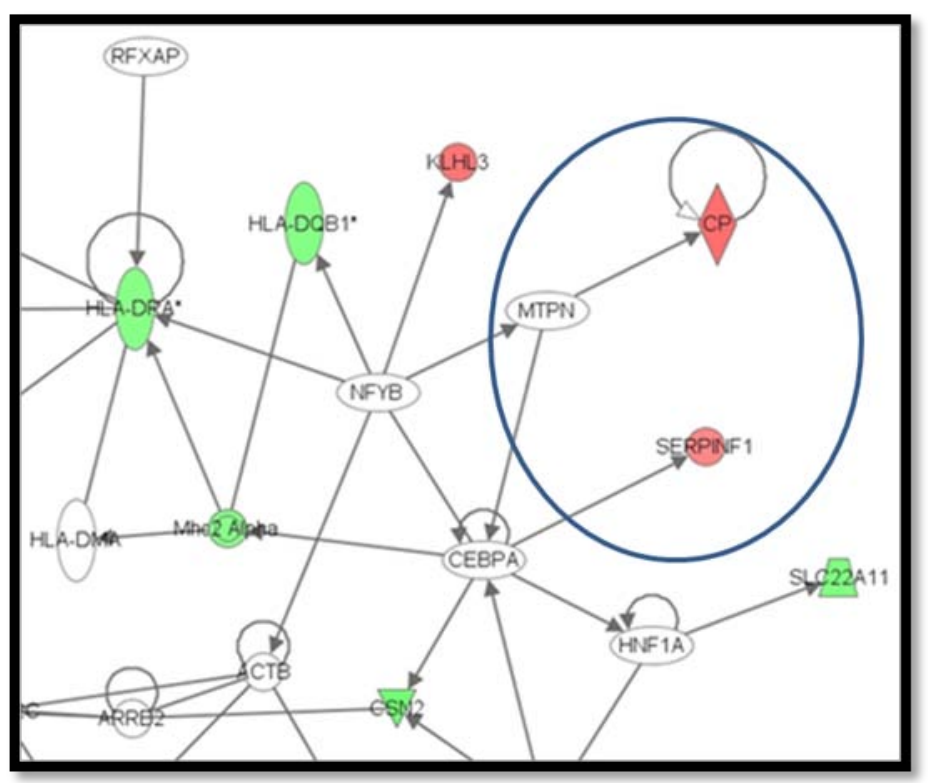

Figura 20: Rede de ligações gênicas na linhagem HB4aC5.2.Circulado em azul observa-se o envolvimento do CP com SERPINF1. Genes preenchidos na cor verde simbolizando a hipoexpressão e em vermelho a hiperexpressão. 
Em relação aos genes hipoexpressos nessa linhagem, na Figura 21, verifica-se o envolvimento de diversos genes na mesma rede biológica hipotética. Observa-se, que uma das relações destes genes parece ser a localização das proteínas codificadas por estes genes. Por exemplo, o GRM8 (glutamate receptor, metabotropic 8), CXCR2, S1PR1 e NPY (neuropeptide Y) codificam receptores localizados na membrana plasmática. Assim como genes que codificam receptores acoplados à proteína G, como o GPR78 (G protein-coupled receptor 78) e o GPR85 (G protein-coupled receptor 85 ).

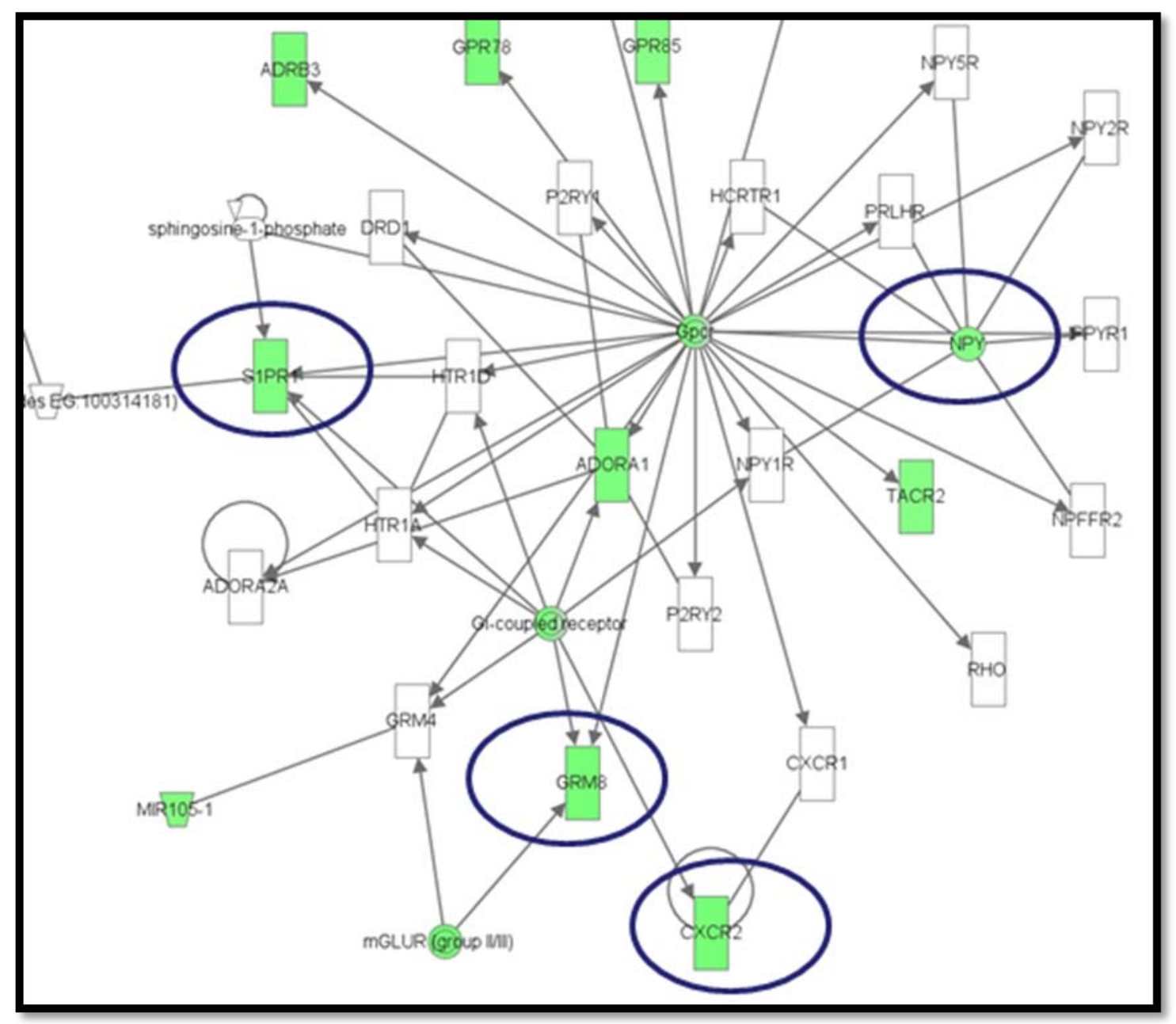

Figura 21: Rede de ligações gênicas na linhagem HB4aC5.2. Circulado em azul alguns exemplos de genes codificadores de proteínas localizadas na membrana celular. Genes preenchidos na cor verde simbolizando a hipoexpressão. 
Analisamos também as redes biológicas hipotéticas com os DEGs da linhagem SKBR3. Foram encontrados alguns genes relacionados com o processo de adesão celular. Determinados genes deste grupo, foram relacionados na rede biológica hipotética, com ligação indireta com o TNF, como o AOC3 (amine oxidase, copper containing 3 - vascular adhesion protein 1) e o ADAM23 (ADAM metallopeptidase domain 23), verificado na Figura 22.

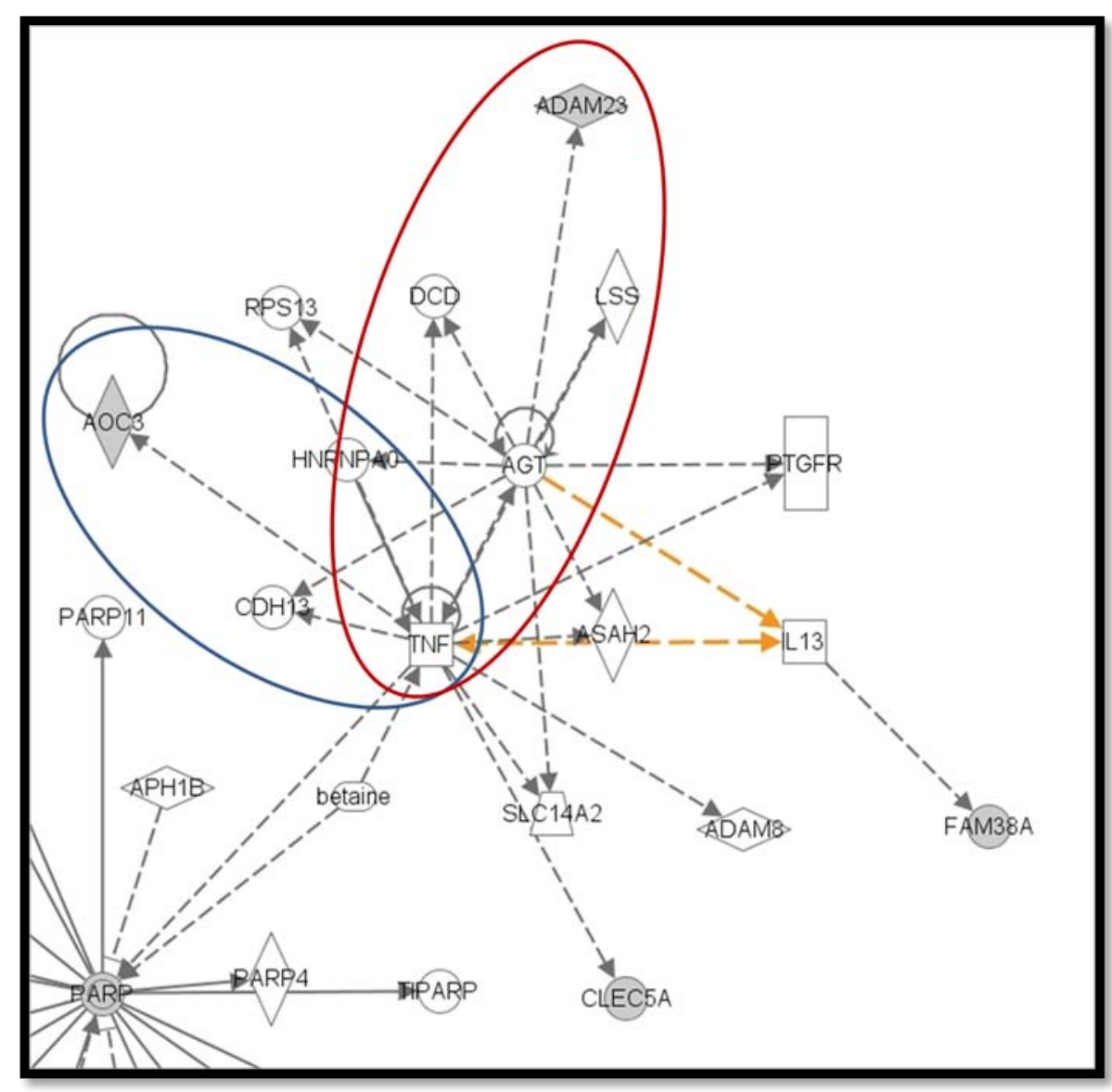

Figura 22: Rede de ligações gênicas na linhagem SKBR-3.Circulado em azul a ligação indireta do $A O C 3$ com TNF. Circulado em vermelho a ligação indireta do TNF com ADAM23.

O maior grupo de genes relacionados numa mesma rede biológica hipotética nesta linhagem foi associado com metabolismo lipídico. Por exemplo, os genes já pré-selecionados como LDLR (low density lipoprotein 
receptor), DHCR7(7-dehydrocholesterol reductase), SC4MOL(sterol-C4methyl oxidase-like), INSIG1 (insulin induced gene 1), DDX60L (DEAD (AspGlu-Ala-Asp) box polypeptide 60-like),AKR1D1(aldo-keto reductase family 1, member D1, delta 4-3-ketosteroid-5-beta-reductase), THRSP(thyroid hormone responsive) e SCD (stearoyl-CoA desaturase- delta-9-desaturase) estão envolvidos de alguma forma com o metabolismo lipídico e foram hipoexpressos após o tratamento. O único envolvido com o metabolismo lipídico que se apresentou hiperexpresso após o tratamento foi o PDK4.

Destes DEGs hipoexpressos após o tratamento, o INSIG1, THRSP e SCD, LDLR, DHCR7 e SC4MOL estão envolvidos com o mesmo fator transcricional SREBP (ou SREBF1- sterol regulatory element binding transcription factor 1) como observado na Figura 23.

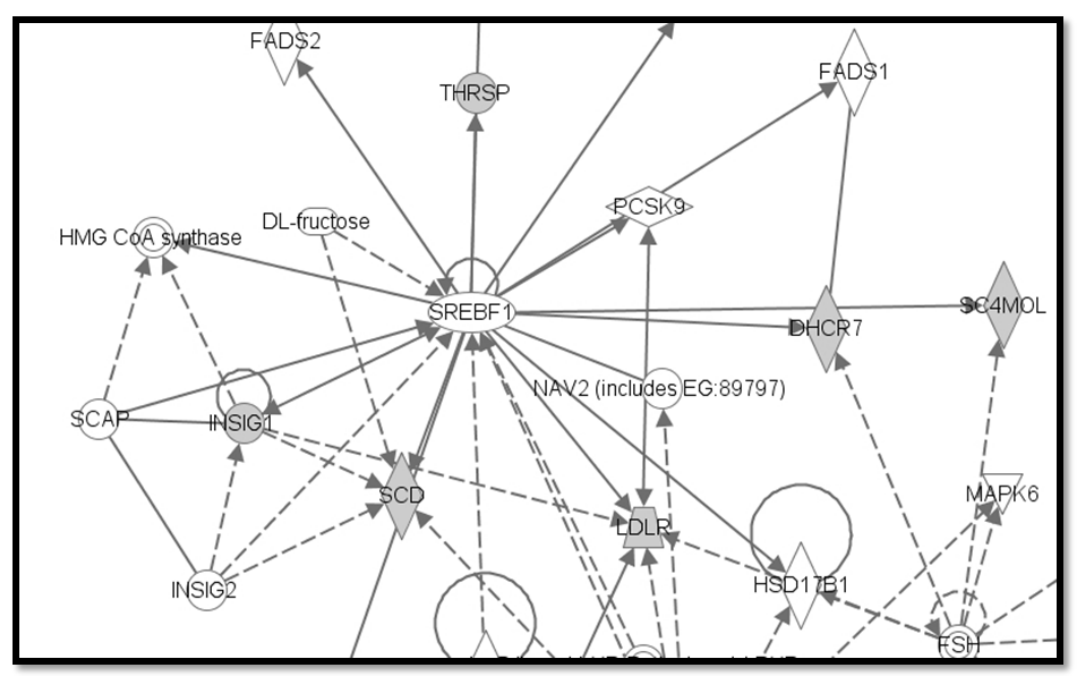

Figura 23: Rede de ligações gênicas na linhagem SKBR-3. DEGs envolvidos com o metabolismo lipídico e associados ao mesmo fator transcricional SREBP (SREBF1).

Com o objetivo de avaliar a ação semelhante do DHA nas três linhagens, comparamos os DEGs de cada linhagem. Observamos que na linhagem SKBR-3, os genes associados com metabolismo lipídico na maioria 
são diferentes dos genes envolvidos com metabolismo lipídico encontrados na linhagem HB4a (CPT1A, ANGPTL, APOD e etc).

O único gene encontrado diferencialmente expresso nas duas linhagens (HB4a e SKBR3) é o gene PDK4. Este gene codifica uma proteína localizada na matriz mitocondrial e inibe o complexo piruvato desidrogenase, contribuindo assim para a regulação da glicose. Além de ser regulado pelo fator transcricional $P P A R D^{[75]}$. A regulação nas duas linhagens foi semelhante, porém mais predominante na linhagem HB4a. Nesta houve uma hiperexpressão do PDK4 com um fold change de 4,6204. Enquanto que na SKBR-3 o fold change foi de 1,9110.

$\mathrm{Na}$ comparação entre os genes comuns nas linhagens SKBR-3 e HB4aC5.2 após o tratamento, encontramos dois genes, SCDe LIPN(lipase, family member $N$ ). Em ambas as linhagens houve uma hipoexpressão no gene SCD e no gene LIPN após o tratamento com o DHA. Na linhagem HB4aC5.2 encontramos um fold change de 0,6206 enquanto na linhagem SKBR-3 o fold change foi de 0,5143 para o gene SCD. Para o gene LIPN o fold change foi de 0,4161 e 0,5669 para a linhagem HB4aC5.2 e SKBR-3, respectivamente.

Na comparação entre a linhagem HB4a e HB4aC5.2, não encontramos nenhum gene diferencialmente expresso comum nas duas linhagens após o tratamento com DHA.

\subsection{Análise de DEGs após o tratamento com DHA envolvidos com HER2}

Com a finalidade de encontrar o DEGs envolvidos especificamente com o HER-2 após o tratamento com o DHA, partimos do pressuposto que a linhagem HB4aC5.2 é semelhante a linhagem HB4a com a única diferença da hiperexpressão do HER-2. 
Assim, comparamos a lista de genes diferencialmente expressos após o tratamento com DHA na linhagem HB4a com a lista de genes diferencialmente expressos após o tratamento com DHA na linhagem HB4aC5.2 e procuramos os genes diferentes nessas duas listas. Assim produzimos uma lista de genes exclusivos do HER-2 após o tratamento com DHA. Comparamos esta lista com a lista de genes diferencialmente expressos após o tratamento com DHA na linhagem SKBR-3 e procuramos os genes em comum. Assim obtivemos a confirmação dos genes exclusivos do HER-2 após o tratamento com DHA. Na Figura 24 podemos visualizar um esquema dessa estratégia. Encontramos assim, dois genes regulados pelo HER2 após o tratamento com DHA, o SCD e LIPN, ambos envolvidos com metabolismo lipídico.

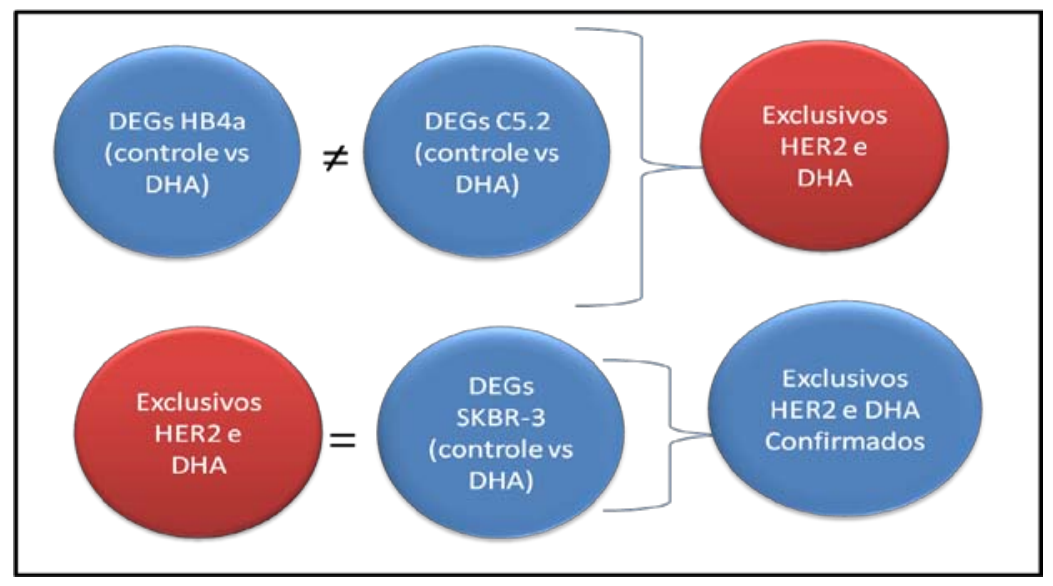

Figura 24: Estratégia para busca de genes diferencialmente expressos após o tratamento com DHA envolvidos com HER-2. 


\subsection{Seleção dos genes candidatos para Validação Técnica por RT qPCR}

A partir dos resultados obtidos pelas análises de bioinformática, analisamos as redes hipotéticas geradas pelo software IPA e utilizamos alguns critérios para selecionar os genes que serão validados por qRT-PCR, como:

1) Função do gene bem estabelecida em banco de dados como NCBI (National Center for Biotechnology Information) para genes (www.ncbi.nlm.nih.gov/gene);

2) Valores de fold change (quantas vezes está alterado em relação ao controle). Genes com valores de fold change $\geq 2,5$ e $\leq 0,5$ foram considerados com maior importância;

3) Relação do gene com câncer de mama;

4) Impacto das publicações que relacionam o gene com diferentes aspectos do câncer de mama.

Dessa maneira, 31 genes foram escolhidos para posterior validação técnica.Sendo 13 genes na linhagem HB4a, 9 genes na linhagem HB4aC5.2 e 10 genes na linhagem SKBR-3. A Tabela 7 mostra, para cada linhagem celular, a função, o símbolo, o nome completo e o fold change dos genes selecionados.A Tabela 8 mostra os primers utilizados para a validação. 
Tabela 7: Genes selecionados para validação técnica por qRT PCR.

\begin{tabular}{|c|c|c|c|c|}
\hline $\begin{array}{l}\text { Linhagem } \\
\text { celular }\end{array}$ & Função & $\begin{array}{l}\text { Simbolo } \\
\text { do Gene }\end{array}$ & Nome do Gene & $\begin{array}{l}\text { Fold } \\
\text { Change }\end{array}$ \\
\hline \multirow{13}{*}{$\underset{\stackrel{\mathscr{f}}{\mathfrak{m}}}{\stackrel{1}{x}}$} & \multirow{3}{*}{$\begin{array}{l}\text { Adesão } \\
\text { Celular }\end{array}$} & CLDN1 & claudin 1 & 1,754 \\
\hline & & SDC1 & syndecan 1 & 1,367 \\
\hline & & CD36 & CD36 molecule (thrombospondin receptor) & 1,783 \\
\hline & \multirow{4}{*}{$\begin{array}{l}\text { Metabolismo } \\
\text { Lipídico }\end{array}$} & PDK4 & pyruvate dehydrogenase kinase, isozyme 4 & 4,620 \\
\hline & & CPT1A & carnitine palmitoyltransferase $1 A$ (liver) & 2,151 \\
\hline & & ANGPTL4 & angiopoietin-like 4 & 1,782 \\
\hline & & ACADVL & acyl-CoA dehydrogenase, very long chain & 1,327 \\
\hline & \multirow{4}{*}{$\begin{array}{l}\text { Diferenciação } \\
\text { Celular }\end{array}$} & PLIN2 & perilipin 2 & 4,222 \\
\hline & & CDKN1A & cyclin-dependent kinase inhibitor $1 \mathrm{~A}$ & 1,444 \\
\hline & & $F A B P 3$ & $\begin{array}{l}\text { fatty acid binding protein 3, muscle and heart } \\
\text { (mammary-derived growth inhibitor) }\end{array}$ & 1,344 \\
\hline & & SERPINB5 & $\begin{array}{l}\text { serpin peptidase inhibitor, clade B (ovalbumin), } \\
\text { member } 5\end{array}$ & 1,526 \\
\hline & $\begin{array}{l}\text { Transporte } \\
\text { Celular }\end{array}$ & SLC25A20 & $\begin{array}{l}\text { solute carrier family } 25 \text { (carnitine/acylcarnitine } \\
\text { translocase), member } 20\end{array}$ & 1,686 \\
\hline & $\begin{array}{l}\text { Down- } \\
\text { regulados }\end{array}$ & MKI67 & antigen identified by monoclonal antibody Ki-67 & 0,592 \\
\hline \multirow{9}{*}{ 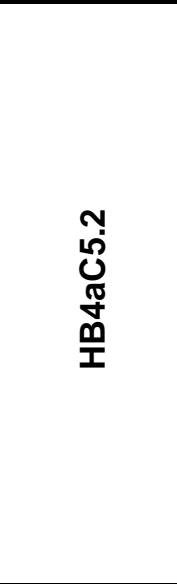 } & \multirow[t]{2}{*}{$\begin{array}{l}\text { Invasão e } \\
\text { Metástase }\end{array}$} & SERPINF1 & $\begin{array}{l}\text { serpin peptidase inhibitor, clade } F \text { (alpha-2 } \\
\text { antiplasmin, pigment epithelium derived factor), } \\
\text { member } 1\end{array}$ & 1,207 \\
\hline & & S1PR1 & sphingosine-1-phosphate receptor 1 & 0,738 \\
\hline & \multirow{3}{*}{$\begin{array}{l}\text { Membrana } \\
\text { Celular }\end{array}$} & CXCR2 & chemokine (C-X-C motif) receptor 2 & 0,689 \\
\hline & & GRM8 & glutamate receptor, metabotropic 8 & 0,678 \\
\hline & & PF4 & platelet factor 4 & 0,702 \\
\hline & $\begin{array}{l}\text { Metabolismo } \\
\text { Lipídico }\end{array}$ & NPY & neuropeptide $Y$ & 0,761 \\
\hline & \multirow{3}{*}{$\begin{array}{l}\text { Sistema } \\
\text { Imune }\end{array}$} & TARP & TCR gamma alternate reading frame protein & 0,632 \\
\hline & & $C P$ & ceruloplasmin (ferroxidase) & 1,453 \\
\hline & & $R B L 1$ & retinoblastoma-like 1 (p107) & 0,686 \\
\hline \multirow{10}{*}{$\begin{array}{l}m \\
\dot{\alpha} \\
\dot{\alpha} \\
\dot{v} \\
\dot{v}\end{array}$} & $\begin{array}{l}\text { Adesão } \\
\text { Celular }\end{array}$ & AOC3 & $\begin{array}{l}\text { amine oxidase, copper containing } 3 \text { (vascular } \\
\text { adhesion protein 1) }\end{array}$ & 1,733 \\
\hline & \multirow{6}{*}{$\begin{array}{l}\text { Metabolismo } \\
\text { Lipídico }\end{array}$} & $L D L R$ & low density lipoprotein receptor & 0,736 \\
\hline & & DHCR7 & 7-dehydrocholesterol reductase & 0,743 \\
\hline & & INSIG1 & insulin induced gene 1 & 0,610 \\
\hline & & THRSP & thyroid hormone responsive (SPOT14 homolog, rat) & 0,404 \\
\hline & & PDK4 & pyruvate dehydrogenase kinase, isozyme 4 & 1,911 \\
\hline & & $S C D$ & stearoyl-CoA desaturase (delta-9-desaturase) & 0,514 \\
\hline & \multirow{2}{*}{$\begin{array}{l}\text { Múltiplas } \\
\text { Respostas }\end{array}$} & PTPRZ1 & $\begin{array}{l}\text { protein tyrosine phosphatase, receptor-type, } Z \\
\text { polypeptide } 1\end{array}$ & 0,795 \\
\hline & & GSTA1 & glutathione S-transferase alpha 1 & 1,442 \\
\hline & Inflamação & TNFSF4 & tumor necrosis factor (ligand) superfamily, member4 & 0,671 \\
\hline
\end{tabular}


Tabela 8: Primers forward e reverse desenhados para genes diferencialmente expressos selecionados para validação técnica.

\begin{tabular}{|c|c|c|c|}
\hline $\begin{array}{c}\text { Linhagem } \\
\text { celular }\end{array}$ & Genes & Forward & Reverse \\
\hline \multirow{13}{*}{ 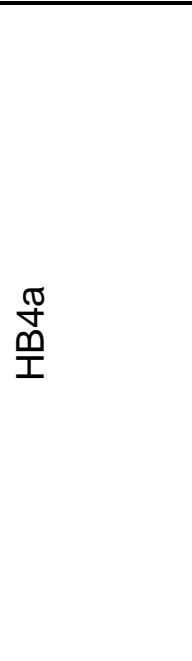 } & CLDN1 & TCTATGACCCTATGACCCCAG & TGGTGTTGGGTAAGAGGTTG \\
\hline & SDC1 & ССТТСАСАСТССССАСАС & GCCACTACAGCCGTATTCTC \\
\hline & $C D 36$ & TCCTTGGCCTGATAGAAATGATC & AATTGGTTTGTGCTTGAGCC \\
\hline & $P D K 4$ & TGCCCCGAGAGGTGGAGCATT & TGGCGAGTCTCACAGGCAATTCTTG \\
\hline & CPT1A & ACCCAGAGTACGTGTCCAG & TCCAAAGCGATGAGAATCCG \\
\hline & ANGPTL4 & GCCAGTTGACCCGGCTCACAAT & GGAGACCCCTGAGGCTGGATTTCA \\
\hline & $A C A D V L$ & GGGGCTTCGGGGGCATTACC & CACGTTCTCCGATGGCACCCG \\
\hline & PLIN2 & GTGGCAGCCGGAGTCGTCTTC & AGGTTGACCACCCGAGTCACCA \\
\hline & CLCA2 & GCACCCCAGCCCACTCTATTCCA & AAAGCCCCACTTTCGСTССТССТ \\
\hline & FABP3 & AGAAATGGGACGGGCAAG & ACAGTGCAGTCAGGTCATG \\
\hline & SERPINB5 & GTGCTCCTCGCTTGCCTGTTCC & GGACATTGCCCAGTGGCTCCTTT \\
\hline & SLC25A20 & GCCAAAACCCATCAGCCCGCT & CAGGCAAACTCGGTGGCTGTGT \\
\hline & MKI67 & TGCCTGCTCGACCCTACAGAGTG & CTGCGGTTGCTCCTTCACTGGG \\
\hline \multirow{10}{*}{$\stackrel{\sim}{ن}$} & SERPINF1 & ATGAAGGCGAAGTCACCAAGTCCCT & TCCACTCAAAGCCAGCCCGGT \\
\hline & S1PR1 & AGCGAGCCGTACAGATCCCGG & CACTGGCTTCAGGGGTGGTTCG \\
\hline & CXCR2 & TTGTTGGCTCTTCTTCAGGG & TGAGGCTTGGAATGTGACTG \\
\hline & GRM8 & CATTTGGTTAGCTTTCATCCCC & ACCTTGGGCATATAGAGCATG \\
\hline & PF4 & СССАСТGCССАACTGATAG & GCAAATGCACACACGTAGG \\
\hline & $N P Y$ & TGGAAAACGATCCAGCCCAGAGACA & TCCCATCACCACATTGCAGGGTCT \\
\hline & $L I P N$ & TGCATATAAAACAGCTTTACCACTC & ACCAGCCCAAATAGCAGTAG \\
\hline & $C P$ & CCTGGAACATACCAAACCCTAG & TCATTCAGCCAGATTTGGTGT \\
\hline & $R B L 1$ & TTCCCCGCACAAGAATGG & ATCGATGGCTATTACTCGCTTC \\
\hline & $S C D$ & GGAGATAAGTTGGAGACGATGC & TCCAGACATATTCAACCTTGGG \\
\hline \multirow{8}{*}{$\begin{array}{l}\frac{m}{\tilde{r}} \\
\tilde{y} \\
\frac{\underline{v}}{\omega}\end{array}$} & AOC3 & ATTCCTCTTTGGTGCTACTGG & GGACAAAGACCATATCCTCGG \\
\hline & $L D L R$ & CACATTTGCCACAACCAGG & TCTTTGAATAAAACAAGGCCGG \\
\hline & DHCR7 & CTGCCTTATCTTTACACGCTG & GGAACAGGTCCTTCTGGTG \\
\hline & INSIG1 & ССTCTATATTCGTTCTTGGCTCC & АTCTTCCTTGCTCTCAGAATCG \\
\hline & THRSP & CTCACCGAGAAAGCCCAGGAGGT & AACTGCTCCGCCGACCTCATCA \\
\hline & PTPRZ1 & TGTGGAAAGATCAAGGGTTGG & GATGGTATGAAGGAGAGGGTG \\
\hline & GSTA1 & CGGTGACAGCGTTTAACAAAG & ТTСТСТTСАААСТСТАСТССАGC \\
\hline & TNFSF4 & СTCCTGTGCTTCACCTACATC & TTGGGAAGTGAGGATGAAACC \\
\hline
\end{tabular}




\subsection{Validação Técnica por RT-qPCR}

Selecionamos 13 genes para validação técnica por RT-qPCR. São eles: PLIN2, FABP3, ACADVL, CLCA2, CLDN1, CPT1A, MKI67, SLC25A30, SERPINB5, PDK4, ANGPTL4, SDC1, CD36. Desses, 8 genes (PLIN2, FABP3, CLCA2, CPT1A, MKI67, PDK4, ANGPTL4, CD36) foram validados pela reação de RT-qPCR. Apenas um gene (SDC1) foi observado como hipoexpresso na reação de RT-qPCR, apresentando discordância nos dados do Microarray (hiperexpresso com fold change de 1.3) em relação aos dados do RT-qPCR (Figura 25 e Tabela 9).

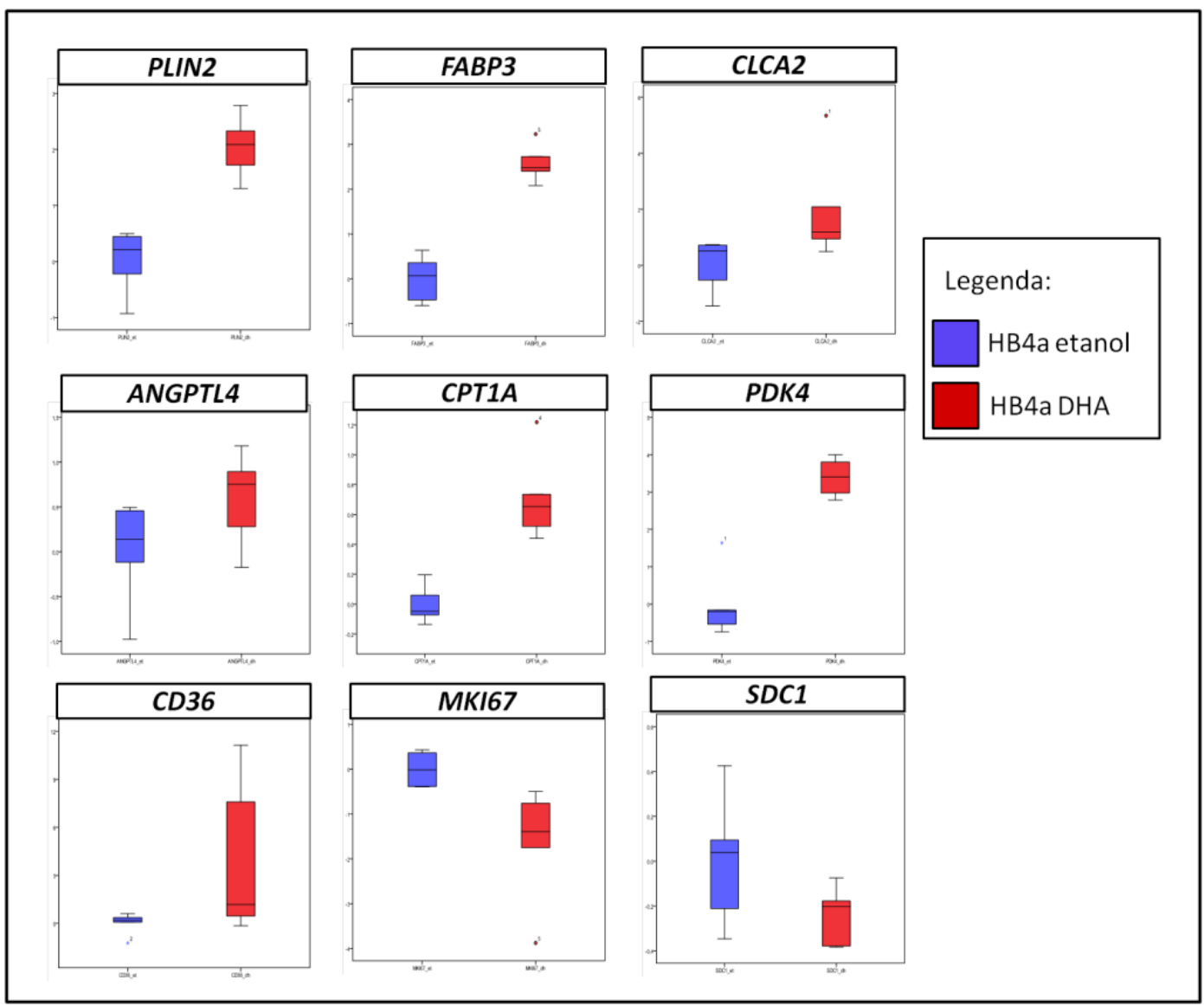

Figura 25: Box plots representativos da expressão gênica dos genes selecionados na linhagem HB4a por RT-PCR com significância estatística ( $p$ $<0,05)$ 
$\mathrm{Na}$ Tabela 9 observamos os genes selecionados para validação técnica o fold change e o valor significância encontrado na técnica de RTqPCR.

Tabela 9. DEGs selecionados para validação técnica por RT-qPCR na linhagem HB4a

\begin{tabular}{|c|c|c|c|c|c|}
\hline & \multicolumn{3}{|c|}{ Microarray $^{\dagger}$} & \multicolumn{2}{|c|}{ RT-qPCR* } \\
\hline $\begin{array}{l}\text { Símbolo } \\
\text { do Gene }\end{array}$ & $\begin{array}{c}\text { Fold } \\
\text { Change }\end{array}$ & $\begin{array}{l}\text { Hiper }(\uparrow) \text { ou } \\
\text { Hipo }(\downarrow)\end{array}$ & Valor de $p$ & $\begin{array}{l}\text { Hiper }(\uparrow) \text { ou } \\
\text { Hipo }(\downarrow)\end{array}$ & Valor de $p$ \\
\hline PLIN2 & 4,222 & $\uparrow$ & $<0,05$ & $\uparrow$ & 0,043 \\
\hline FABP3 & 1,344 & $\uparrow$ & $<0,05$ & $\uparrow$ & 0,043 \\
\hline$A C A D V L$ & 1,327 & $\uparrow$ & $<0,05$ & $\uparrow$ & 0,686 \\
\hline CLCA2 & 2,562 & $\uparrow$ & $<0,05$ & $\uparrow$ & 0,043 \\
\hline CLDN1 & 1,754 & $\uparrow$ & $<0,05$ & $\uparrow$ & 0,893 \\
\hline CPT1A & 2,151 & $\uparrow$ & $<0,05$ & $\uparrow$ & 0,043 \\
\hline MKI67 & 0,592 & $\downarrow$ & $<0,05$ & $\downarrow$ & 0,043 \\
\hline SLC25A30 & 2,013 & $\uparrow$ & $<0,05$ & $\uparrow$ & 0,138 \\
\hline SERPINB5 & 1,526 & $\uparrow$ & $<0,05$ & $\uparrow$ & 0,500 \\
\hline PDK4 & 4,620 & $\uparrow$ & $<0,05$ & $\uparrow$ & 0,043 \\
\hline ANGPTL4 & 1,782 & $\uparrow$ & $<0,05$ & $\uparrow$ & 0,043 \\
\hline SDC1 & 1,367 & $\uparrow$ & $<0,05$ & $\downarrow$ & 0,043 \\
\hline$C D 36$ & 1,783 & $\uparrow$ & $<0,05$ & $\uparrow$ & 0,043 \\
\hline
\end{tabular}

\footnotetext{
$\dagger$ Teste SAM

* Teste Wilcoxon Signed Ranks
} 
$\mathrm{Na}$ linhagem HB4aC5.2 dos 208 genes diferencialmente expressos $(p<0,01)$, sendo 32 hiper-regulados e 176 hipo-regulados, foram escolhidos 9 DEGs para a validação técnica por RT-qPCR, sendo 2 hiper-expressos (CP e SERPINF1) e 7 hipo-expressos (S1PR1, CXCR2, PF4, RBL1, PF4, NPY, TARP). Três desses genes PF4, NPY e TARP não foram padronizados na curva de eficiência da reação de qPCR apesar de terem sido feitos diferentes primers. Na Figura 26 visualizamos os Box plots representativos dos genes selecionados para validação técnica da linhagem HB4aC5.2.

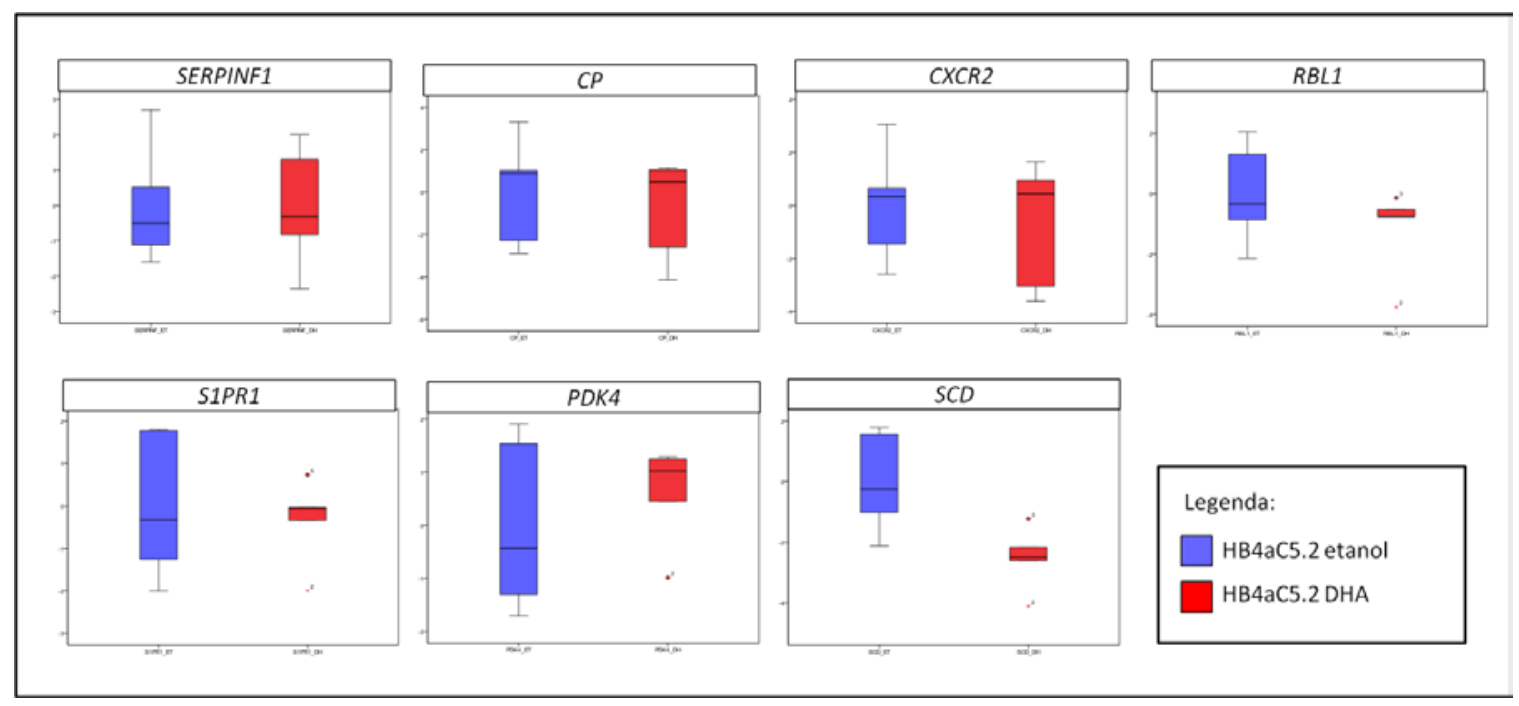

Figura 26: Box plots representativos da expressão gênica dos genes selecionados na linhagem HB4aC5.2 por RT-qPCR. 
Na Tabela 10 verificam-se os DEGs com o resultado de Microarray e os valores de RT-qPCR. Não foi encontrado nenhum valor estatisticamente significante nessa linhagem.

Tabela 10. Análise estatística do RT-qPCR em tempo real para os DEGs selecionados para validação técnica na linhagem HB4aC5.2.

\begin{tabular}{lccccc}
\hline \multicolumn{5}{c}{ Microarray $^{\dagger}$} & \multicolumn{3}{c}{ RT-qPCR $^{\star}$} \\
\hline $\begin{array}{l}\text { Símbolo } \\
\text { do Gene }\end{array}$ & $\begin{array}{c}\text { Fold } \\
\text { Change }\end{array}$ & $\begin{array}{c}\text { Hiper }(\uparrow) \text { ou } \\
\text { Hipo }(\downarrow)\end{array}$ & Valor de $p$ & $\begin{array}{c}\text { Hiper }(\uparrow) \text { ou } \\
\text { Hipo }(\downarrow)\end{array}$ & $\begin{array}{c}\text { Valor de } \\
\text { p }\end{array}$ \\
\hline SERPINF1 & 1,207 & $\uparrow$ & $<0,05$ & $\uparrow$ & 0,893 \\
S1PR1 & 0,738 & $\downarrow$ & $<0,05$ & $\downarrow$ & 0,686 \\
CXCR2 & 0,689 & $\downarrow$ & $<0,05$ & $\downarrow$ & 0,500 \\
CP & 1,453 & $\uparrow$ & $<0,05$ & $\uparrow$ & 0,500 \\
RBL1 & 0,686 & $\downarrow$ & $<0,05$ & $\uparrow$ & 0,225 \\
SCD & 0,620 & $\downarrow$ & $<0,05$ & $\downarrow$ & 0,080 \\
\hline
\end{tabular}

† Teste SAM

* Teste Wilcoxon Signed Ranks 
$\mathrm{Na}$ linhagem SKBR-3 dos 126 genes diferencialmente expressos $(p<0,01)$, sendo 48 hiper-expressos e 78 hipo-expressos, selecionamos 7 genes para a validação técnica. Sendo 3 hiper-expressos: AOC3, PDK4 e GSTA1 (glutathione S-transferase alpha 1) e 7 hipo-expressos: LDLR, DHCR7, INSIG1, THRSP,SCD, PTPRZ1 (protein tyrosine phosphatase, receptor-type, Z polypeptide 1), TNFS4 (tumor necrosis factor (ligand) superfamily, member 4). Na Figura 27 visualizamos os Box plots representativos dos genes selecionados para validação técnica da linhagem SKBR-3. Os genes DHCR7, INSIG1 e LDLR apresentaram significância estatística.
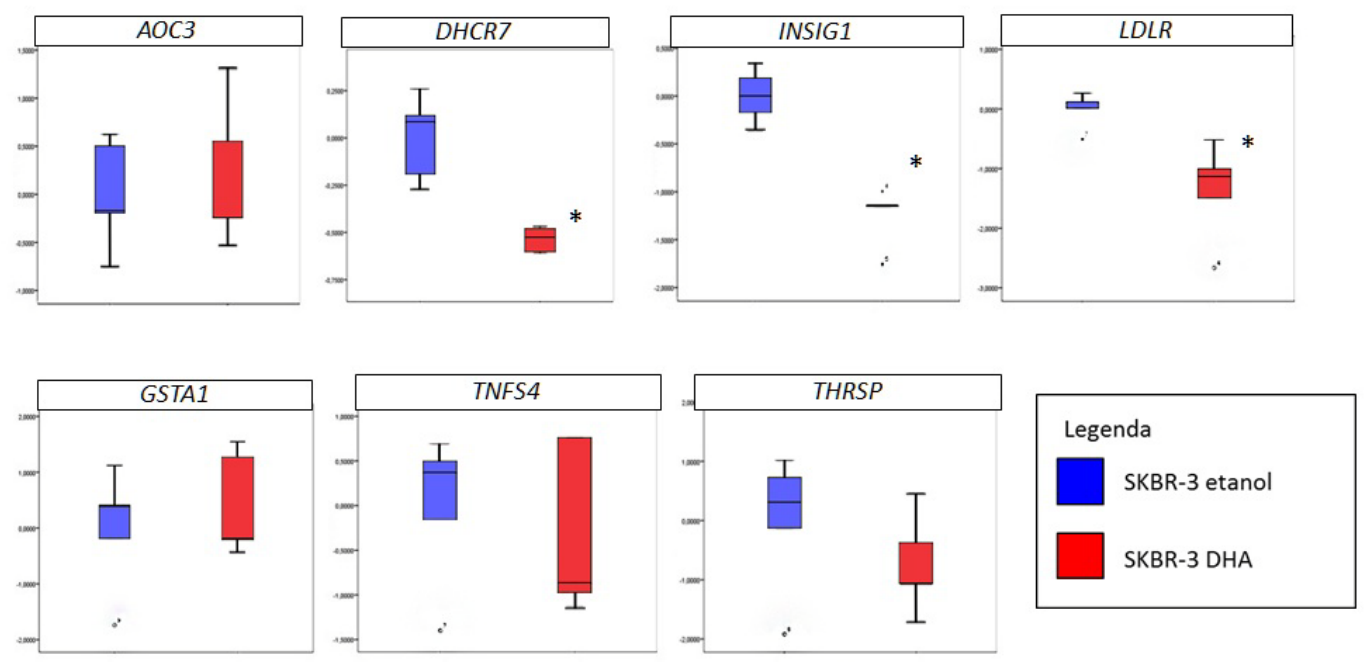

Figura 27: Box plots representativos da expressão gênica dos genes selecionados na linhagem SKBR-3 por RT-qPCR. * $p=0,008$ 
Na Tabela 11 observamos os genes escolhidos para validação técnica por RT-qPCR. Os genes INSIG1, DHCR7, LDLR apresentaram a mesma tendência do microarray e tiveram significância estatística.

Tabela 11. Análise estatística do RT-qPCR em tempo real para os DEGs selecionados para validação técnica na linhagem SKBR-3

\begin{tabular}{lccccc}
\hline \multicolumn{3}{c}{ Microarray $^{\dagger}$} & \multicolumn{2}{c}{ RT-qPCR $^{\star}$} \\
\hline $\begin{array}{l}\text { Símbolo } \\
\text { do Gene }\end{array}$ & $\begin{array}{c}\text { Fold } \\
\text { Change }\end{array}$ & $\begin{array}{c}\text { Hiper }(\uparrow) \text { ou } \\
\text { Hipo }(\downarrow)\end{array}$ & Valor de p & $\begin{array}{c}\text { Hiper }(\uparrow) \text { ou } \\
\text { Hipo }(\downarrow)\end{array}$ & Valor de $p$ \\
\hline TNFSF4 & 0,671 & $\downarrow$ & $<0,05$ & $\downarrow$ & 0,685 \\
THRSP & 0,404 & $\downarrow$ & $<0,05$ & $\downarrow$ & 0,500 \\
INSIG1 & 0,609 & $\downarrow$ & $<0,05$ & $\downarrow$ & $\mathbf{0 , 0 0 8}$ \\
GSTA1 & 1,441 & $\uparrow$ & $<0,05$ & $\uparrow$ & 0,841 \\
DHCR7 & 0,742 & $\downarrow$ & $<0,05$ & $\downarrow$ & $\mathbf{0 , 0 0 8}$ \\
AOC3 & 1,733 & $\uparrow$ & $<0,05$ & $\uparrow$ & $\mathbf{1 , 0 0 0}$ \\
LDLR & 0,736 & $\downarrow$ & $<0,05$ & $\downarrow$ & $\mathbf{0 , 0 0 8}$ \\
\hline
\end{tabular}

† Teste SAM

* Teste Wilcoxon Signed Ranks 


\subsection{DISCUSSÂO}

A análise dos efeitos do DHA no perfil de expressão gênica nas linhagens mamárias HB4a, HB4aC5.2 e SKBR-3 nos fornece informações sobre a ação do DHA no tecido mamário normal e tumorigênico.

Realizamos a técnica de Microarray nas três linhagens celulares

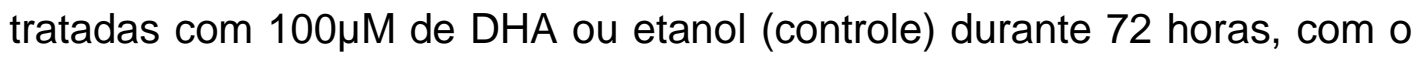
intuito de melhorar o entendimento desse ácido graxo em linhagens celulares de câncer de mama.

A escolha da linhagem HB4a nos possibilitou avaliar a ação do DHA em uma célula com o fenótipo normal, representando um modelo para observação fisiológica do efeito de DHA. Nesta linhagem, encontramos 174 genes diferencialmente expressos $(p<0,01)$, sendo 136 hiperexpressos e 38 hipoexpressos. Estes genes estão relacionados com processos de adesão celular, metabolismo lipídico e diferenciação celular, destacando que todos esses processos são importantes para a quimioprevenção do câncer ${ }^{(30,31)}$.

O uso da linhagem HB4aC5.2 permitiu analisar células transformadas com fenótipo hiperproliferativo e planejadas especificamente para hiperexpressar HER-2. Como estas células se assemelham à sua linhagem de origem (HB4a), foi possível observar os efeitos específicos do DHA em relação à hiperexpressão de HER-2. Nesta linhagem foram encontrados 208 genes diferencialmente expressos $(p<0,01)$, sendo 32 hiperexpressos e 176 hipoexpressos. Adicionalmente, foram selecionados dois genes envolvidos com o HER2 após o tratamento, o SCD e LIPN os quais discutiremos adiante.

A linhagem SKBR-3 permitiu avaliar os efeitos do DHA em células com fenótipo invasivo, metastático e múltiplas aberrações genéticas além da hiperexpressão dos receptores HER-2. Observamos, nesta linhagem, 126 genes diferencialmente expressos $(p<0,01)$, sendo 48 hiperexpressos 
e 78 hipoexpressos. Estes genes estão relacionados principalmente com metabolismo lipídico.

O aumento da biossíntese lipídica é uma característica de alguns cânceres. A desregulação da lipogênese tem um papel fundamental na sobrevivência do tumor ${ }^{[76]}$. Adicionalmente, chama a atenção, a associação entre a hiperexpressão do receptor HER-2 e modificações do metabolismo lipídico celular. Em particular na amplificação da região cromossômica 17q12-21, onde o gene do receptor HER-2(ERBB2) está localizado, encontram-se fatores de transcrição como NR1D1(nuclear receptor subfamily 1 group D member 1) e PBP (peroxisome proliferator activated receptor gamma binding protein), atuantes da via de síntese de ácidos graxos (AG) de novo. A produção de um alto nível de lipídios resultantes do aumento da expressão desses genes, provavelmente contribui para um metabolismo energético celular anormal, com o aumento da produção de energia necessária para a sobrevivência desregulada desse subtipo de câncer ${ }^{[77]}$.

Nossos resultados mostraram que o DHA pode agir de maneira diferente em cada tipo celular cabendo discutir em separado cada uma delas.

\subsection{Efeitos específicos na expressão gênica após o tratamento com}

\section{DHA em cada linhagem:}

\section{Linhagem HB4a:}

Nesta linhagem é interessante avaliar alguns genes envolvidos com o processo de diferenciação celular por se tratar de uma linhagem semelhante ao fenótipo do tecido de origem. Estudos demonstraram que o processo de diferenciação celular pode ajudar na prevenção do câncer [78, 79]. O gene PLIN 2, encontrado hiperexpresso em nosso estudo, codifica para uma proteína associada à vesículas lipídicas. Ela possui papel principal na absorção e estoque de ácidos graxos, além de ser 
ativada principalmente por ácidos graxos de cadeia longa [80] Adicionalmente, estudos propõem que esta proteína tem um papel central na formação e secreção de lipídios do leite ${ }^{\left[{ }^{81]}\right.}$ e, assim, esse gene pode estar envolvido com o processo de diferenciação celular mamária ${ }^{[82]}$. A parada de ciclo celular é um indício do processo de diferenciação celular [78]. O gene CDKN1A (cyclin-dependent kinase inhibitor 1A) codifica uma proteína regulatória do ciclo celular ${ }^{[83]}$. No nosso estudo, encontramos esse gene hiperexpresso após o tratamento com DHA.

A proteína codificada pelo gene FABP3 (fatty acid binding protein 3) participa da absorção, metabolismo intracelular e transporte de ácidos graxos de cadeia longa ${ }^{[84]}$. Está envolvido com a síntese de lipídeos do leite ${ }^{[85]}$. Além disso, pode ser ativado pelo fator transcricional PPARG ${ }^{[86]}$. Neste trabalho, a expressão do gene FABP3 aumentou após o tratamento com o DHA. Corroborando com esse dado, Wang e colaboradores demonstraram que a proteína MRG (ou $B-F A B P$, membro da família de FABPs) participa da diferenciação celular mamária. Além disso, eles observaram que o tratamento com DHA em células de câncer de mama, MDA-MB-231, MDA-MB-436, e MDA-MB-468, aumenta a expressão da proteína MRG e diminui a proliferação dessas células. Demonstrando assim, o envolvimento do DHA na regulação desse gene ${ }^{[87]}$.

Além disso, outro gene hiperexpresso no nosso estudo, SERPINB5 (serpin peptidase inhibitor, clade B), conhecido também como maspin, está envolvido na diferenciação celular de linhagens de mama ${ }^{[88]}$ e pode atuar como supressor de tumor neste tipo de câncer ${ }^{[89]}$.

O gene CLDN1(claudin 1) codifica uma proteína componente do complexo proteico tight junction nas células epiteliais participando do processo de adesão celular. A quebra da barreira celular e a desregulação de genes envolvidos com o complexo tight junction está associada com os principais passos para a invasão e metástase tumoral $^{[90]}$. Adicionalmente, este gene foi proposto como supressor de tumor em câncer de mama ${ }^{[91]}$. 
Envolvido também com o processo de adesão celular, sindecans são uma família de proteoglicanos transmembrana de heparam sulfato. Estes mediam a ligação, sinalização celular e a organização do citoesqueleto $^{[92,}$ 93]. O gene SDC1 (syndecan 1), codifica uma sindecan dessa família e oferece relevância, pois além de estar relacionado com o processo de adesão celular, apresenta relação com os AG n-3. Alguns estudos demonstraram em células de câncer de mama, após a suplementação com AG n-3, um aumento significativo na expressão gênica de $S D C 1^{[25}$, 94]. Ainda referente ao processo de adesão celular, observamos a expressão aumentada do gene CD36. A proteína codificada por este gene é um receptor transmembrana e pode exercer função de transporte de ácidos graxos ${ }^{[95]}$.

Os genes diferencialmente expressos envolvidos com metabolismo lipídico foram o PDK4 (pyruvate dehydrogenase kinase, isozyme 4), CPT1A (carnitine palmitoyltransferase 1A), ANGPTL4 (angiopoietin-like 4), ACADVL (acyl-CoA dehydrogenase, very long chain) . O gene PDK4 codifica uma proteína da família do piruvato desidrogenase quinase, cuja função principal é a manutenção da homeostase metabólica ${ }^{[75]}$. A expressão deste gene é controlada pelo fator de transcrição nuclear PPARs (peroxisome proliferator-activated receptors). Na literatura AG n-3 são descritos como ligantes diretos dos PPARs ${ }^{[96]}$. Além disso, um estudo demonstrou que altos níveis de AG livres estão associados com a regulação da expressão do $P D K 4{ }^{[97]}$.

O gene AGPTL4 codifica uma proteína envolvida na regulação da homeostase da glicose, além de estar envolvida no metabolismo lipídico [98] Adicionalmente, foi demonstrado que o AGPTL4 também pode ser ativado pelo fator transcricional nuclear $\operatorname{PPAR}^{[98]}$.

O gene $A C A D V L$ codifica uma proteína principal na via de betaoxidação mitocondrial de ácidos graxos ${ }^{[99,100]}$. A desregulação desse gene pode estar envolvida com a produção de estresse oxidativo ${ }^{[101]}$. 
Escolhemos um gene de transporte celular, SLC25A20 (solute carrier family 25), por estar envolvido no papel central da via de beta-oxidação de AGs e pode ser ativado pelo fator transcricional PPAR ${ }^{[102]}$.

De todos os 38 genes hipoexpressos nessa linhagem, selecionamos apenas o gene MKI67 (antigen identified by monoclonal antibody Ki-67) como de maior importância. Diversos estudos mostram a relação do aumento da proteína Ki-67 com um fenótipo maligno para câncer de mama $^{[103]}$.

\section{Linhagem HB4aC5.2:}

Dos 208 genes diferencialmente expressos $(p<0,01)$, sendo 32 hiperregulados e 176 hipoexpressos, foram escolhidos 9 DEGs para a validação técnica, sendo 2 hiperexpressos $[C P$ (ceruloplasmin) e SERPINF1(serpin peptidase inhibitor, clade F)] e 7 hipoexpressos: S1PR1 (sphingosine-1-phosphate receptor 1), CXCR2(chemokine (C-X-C motif) receptor 2), GRM8(glutamate receptor, metabotropic 8), PF4(platelet factor 4), NPY (neuropeptide Y), TARP(TCR gamma alternate reading frame protein), RBL1(retinoblastoma-like 1).

Destes, escolhemos dois genes com envolvimento no processo de invasão e metástase tumoral. O gene SERPINF1 codifica uma glicoproteina importante na inibição da angiogênese em câncer de mama $^{[104]}$. Além disso, Beckers e colaboradores, verificaram que a hiperexpressão do HER-2 pode diminuir a expressão do SERPINF1 ${ }^{[105]}$. Em nosso estudo, observamos um aumento da expressão desse gene após o tratamento com DHA, sugerindo uma possível participação na inibição do processo de angiogênese.

O outro gene hiperexpresso selecionado foi o gene CP codifica uma proteína metaloproteinase e pode estar envolvido com câncer de mama $^{[106,107]}$. 
Entre os genes hipoexpressos selecionados, o gene S1PR1 codifica uma proteína de membrana de uma família de proteínas denominadas de receptores acoplados à proteína $G^{[108]}$. O ligante deste receptor, sphingosine 1-phosphate (S1P), é um lipídio bioativo com diversas funções biológicas, incluindo proliferação celular, diferenciação, angiogênese, quimiotaxia e migração ${ }^{[109]}$.

Entre os genes hipoexpressos com o tratamento com DHA salienta-se um gene, CXCR2, que codifica proteínas membro da família de receptores acoplados a proteína G. Estas proteínas podem estar envolvidas com angiogênese em câncer de mama ${ }^{[110]}$. Além disso, o aumento da expressão desse gene está relacionado com aumento de angiogênese, desregulação do ciclo celular e diminuição de apoptose em câncer de ovário ${ }^{[111]}$. No entanto no presente estudo ele se manifestou hipoexpresso após o tratamento com DHA, sugerindo um papel benéfico do DHA na ação deste gene.

$\mathrm{Na}$ presente pesquisa, alguns genes hipoexpressos, descritos a seguir, aparentemente não tem ligações em redes biológicas.

O gene PF4, conhecido também como CXCL4,está envolvido com alta agressividade tumoral na mama ${ }^{[12]}$. Borgstrom e col. supõem que a proteína codificada por este gene é um marcador angiogênico para o câncer de mama ${ }^{[113]}$. Assim, o tratamento com o DHA propõe a vantagem de reduzir a expressão deste gene.

O gene GRM8 codifica uma proteína localizada na membrana celular que esta envolvida com a carcinogênese do câncer de mama. No entanto, não estão claros os mecanismos e a importância dessa associação ${ }^{[114}$, 115].

O neuropeptídio Y 5, cujo gene é $N P Y$, em células de câncer de mama, está relacionado a um aumento do crescimento celular. A hiperexpressão desse gene está relacionada a diversos tipos de câncer $^{[116,117]}$. 
O aumento da expressão do gene está associado com células de câncer de mama e próstata ${ }^{[118,119]}$.

O gene RBL1 codifica uma proteína possivelmente atuante como um supressor de tumor ${ }^{[120]}$ e pode estar associado ao receptor HER2 ${ }^{[121]}$.

\section{Linhagem SKBR-3:}

Dos 126 genes diferencialmente expressos $(p<0,01)$, sendo 48 hiperexpressos e 78 hipoexpressos selecionamos 10 genes para a validação técnica. Sendo 3 hiper-expressos: AOC3, PDK4 e GSTA1 (glutathione Stransferase alpha 1) e 7 hipoexpressos: LDLR, DHCR7, INSIG1, THRSP,SCD, PTPRZ1 (protein tyrosine phosphatase, receptor-type, Z polypeptide 1), TNFS4(tumor necrosis factor (ligand) superfamily, member 4).

Entre os genes hipoexpressos, oferecemos atenção aos de metabolismo lipídico. O gene LDLR codifica uma proteína de membrana celular. Esta parece estar envolvida com o metabolismo de colesterol ${ }^{[122]}$. Outro gene associado com o metabolismo de colesterol é o $D H C R 7$, localizada na membrana do retículo endoplasmático ${ }^{[123]}$. Outra proteína da membrana do retículo endoplasmático é a Insig-1, codificada pelo gene. Esta proteína tem papel principal no metabolismo lipídico. A transcrição do INSIG1 envolve o fator transcricional SREBP ${ }^{[124,125]}$. Este fator transcricional também está associado com outros genes de interesse do nosso trabalho, THRSP. Este prediz pior prognóstico para os tumores de mama ${ }^{[126,127]}$. Além disso, AG $n-3$ regulam a expressão desse gene ${ }^{[128,}$ 129].

A enzima delta -9-desaturase é codificada pelo gene $S C D$, essa catalisa o primeiro passo da síntese de $A G s$ insaturados ${ }^{[89]}$. A inibição dessa enzima pode diminuir a proliferação de células de câncer ${ }^{[130]} \mathrm{e} O$ aumento da sua expressão pode aumentar a proliferação de células de câncer de mama ${ }^{[131]}$. 
Ainda entre os genes hipoexpressos, mas envolvidos com o processo imunológico, está o gene TNFSF4 que codifica uma proteína da família dos receptores de fator de necrose tumoral. Este gene parece estar envolvido com tumores de mama ${ }^{[132,133]}$.

Entre os genes hiperexpressos selecionamos o gene GSTA1, que codifica uma proteína envolvida na detoxificação de compostos eletrofílicos, incluindo carcinógenos ${ }^{[134]}$. Além do GSTA1, selecionamos mais 2 genes hiperexpressos: o gene AOC3 que codifica uma proteína que apresenta propriedades de adesão celular ${ }^{[135]}$; e o gene $P D K 4$, que também apresentou-se diferencialmente expresso na linhagem HB4a.

\subsection{Efeitos específicos na expressão gênica associados com HER2 após o tratamento com DHA}

A hiperexpressão do HER-2 está associada ao pior prognóstico em câncer de mama ${ }^{[6]}$, além de estar associada a um caráter lipogênico. Segundo Kourtidis e col. existe um mecanismo lipogênico alterado devido à hiperexpressão de HER-2, o qual desencadeia vias de sinalização que ativam enzimas principais envolvidas na síntese de AGs de novo e facilitam a glicólise aeróbica para a produção de energia ${ }^{[77]}$. Adiciona-se que aumentam a expressão do PPARG, conhecido pelo seu papel bem definido no metabolismo lipídico de diversos tipos celulares [77]. Adicionalmente, análises de microarray do tecido mamário de pacientes com CDIS (carcinoma ductal in situ) classificado como subtipo HER-2, mostraram que a progressão para CIDS de alto grau está correlacionado com alteração no metabolismo lipídico ${ }^{[9]}$.

Dada as devidas proporções da importância do metabolismo lipídico em células que hiperexpressam o HER-2, nossos dados demonstram que é possível alterar o metabolismo lipídico após o tratamento com DHA.

Encontramos apenas dois genes envolvidos exclusivamente pela hiperexpressão do receptor HER-2 após o tratamento com DHA, SCD e 
LIPN, ambos hipoexpressos neste trabalho e associados com o metabolismo lipídico. Segundo Luyimbazi D e colaboradores, a inibição do SCD com RNA de interferência (siRNA) inibe o crescimento de células de câncer de mama e a hiperexpressão causa o aumento da proliferação ${ }^{[131]}$.

Este estudo estabelece informações moleculares importantes para o entendimento do DHA nas células de câncer de mama. Porém, investigações adicionais são necessárias para esclarecer e confirmar os mecanismos do DHA no câncer de mama com possível ação antineoplásica. 
6. Conclusões 


\subsection{CONCLUSÕES}

Nas condições da presente pesquisa, o tratamento com DHA :

1- Altera o perfil de expressão gênica de linhagem mamária normal (HB4a), transformada (HB4aC5.2) e metastática (SKBR-3).

2- Atua de maneira distinta em cada linhagem estudada, dependendo das características fenotípicas.

3- Regula genes envolvidos com o metabolismo lipídico em células que hiperexpressam o receptor HER-2. 
7. Referências Bibliográficas 


\title{
7.0. REFERÊNCIAS BIBLIOGRÁFICAS
}

\author{
As referências desta dissertação foram inseridas através do programa \\ EndNote $\mathrm{X3}$.
}

1. Jemal, A., et al., Global cancer statistics. CA Cancer J Clin. 61(2): p. 69-90.

2. INCA. Estimativas 2012: Incidência de câncer no brasil. 2012 [cited; Available from: http://www.inca.gov.br; .

3. Burstein, H.J., et al., Ductal carcinoma in situ of the breast. N Engl J Med, 2004. 350(14): p. 1430-41.

4. Altenburg, J.D., et al., A synergistic antiproliferation effect of curcumin and docosahexaenoic acid in SK-BR-3 breast cancer cells: unique signaling not explained by the effects of either compound alone. BMC Cancer. 11: p. 149.

5. Arribas, J., et al., p95HER2 and breast cancer. Cancer Res. 71(5): p. 1515-9.

6. Tovey, S.M., et al., Poor survival outcomes in HER2-positive breast cancer patients with low-grade, node-negative tumours. Br J Cancer, 2009. 100(5): p. 680-3.

7. Timms, J.F., et al., Effects of ErbB-2 overexpression on mitogenic signalling and cell cycle progression in human breast luminal epithelial cells. Oncogene, 2002. 21(43): p. 6573-86.

8. Yu, D., et al., Overexpression of c-erbB-2/neu in breast cancer cells confers increased resistance to Taxol via mdr-1-independent mechanisms. Oncogene, 1996. 13(6): p. 1359-65.

9. Tamimi, R.M., et al., Comparison of molecular phenotypes of ductal carcinoma in situ and invasive breast cancer. Breast Cancer Res, 2008. 10(4): p. R67.

10. Institute, W.C.R.F.A. and f.C. Research, Food, Nutrition, Physical Activity,

and the Prevention of Cancer: a Global Perspective. 2007.

11. Romieu, I., Diet and breast cancer. Salud Publica Mex. 53(5): p. 430-9.

12. Cohen, L.A., P.C. Chan, and E.L. Wynder, The role of a high-fat diet in enhancing the development of mammary tumors in ovariectomized rats. Cancer, 1981. 47(1): p. 66-71.

13. Goldin, B.R. and S.L. Gorbach, Effect of diet on the plasma levels, metabolism, and excretion of estrogens. Am J Clin Nutr, 1988. 48(3 Suppl): p. 787-90.

14. Goldin, B.R., et al., Effect of diet on excretion of estrogens in pre- and postmenopausal women. Cancer Res, 1981. 41(9 Pt 2): p. 3771-3.

15. Ingram, D.M., et al., Effect of low-fat diet on female sex hormone levels. J Natl Cancer Inst, 1987. 79(6): p. 1225-9.

16. Wu, A.H., M.C. Pike, and D.O. Stram, Meta-analysis: dietary fat intake, serum estrogen levels, and the risk of breast cancer. J Natl Cancer Inst, 1999. 91(6): p. 529-34.

17. Wynder, E.L., D.P. Rose, and L.A. Cohen, Diet and breast cancer in causation and therapy. Cancer, 1986. 58(8 Suppl): p. 1804-13.

18. Kelsey, J.L., A review of the epidemiology of human breast cancer. Epidemiol Rev, 1979. 1: p. 74-109.

19. Manna, S., et al., Fish oil regulates cell proliferation, protect DNA damages and decrease HER-2/neu and c-Myc protein expression in rat mammary carcinogenesis. Clin Nutr. 29(4): p. 531-7.

20. Turner, L.B., A meta-analysis of fat intake, reproduction, and breast cancer risk: an evolutionary perspective. Am J Hum Biol. 23(5): p. 601-8.

21. Chamras, H., et al., Fatty acid modulation of MCF-7 human breast cancer cell proliferation, apoptosis and differentiation. J Nutr Biochem, 2002. 13(12): p. 711716.

22. Menendez, J.A., R. Lupu, and R. Colomer, Exogenous supplementation with omega3 polyunsaturated fatty acid docosahexaenoic acid (DHA; 22:6n-3) synergistically 
enhances taxane cytotoxicity and downregulates Her-2/neu (c-erbB-2) oncogene expression in human breast cancer cells. Eur J Cancer Prev, 2005. 14(3): p. 263-70.

23. Menendez, J.A., et al., Novel signaling molecules implicated in tumor-associated fatty acid synthase-dependent breast cancer cell proliferation and survival: Role of exogenous dietary fatty acids, p53-p21WAF1/CIP1, ERK1/2 MAPK, p27KIP1, BRCA1, and NF-kappaB. Int J Oncol, 2004. 24(3): p. 591-608.

24. Schley, P.D., et al., Mechanisms of omega-3 fatty acid-induced growth inhibition in MDA-MB-231 human breast cancer cells. Breast Cancer Res Treat, 2005. 92(2): p. 187-95.

25. Sun, H., I.M. Berquin, and I.J. Edwards, Omega-3 polyunsaturated fatty acids regulate syndecan-1 expression in human breast cancer cells. Cancer Res, 2005. 65(10): p. 4442-7.

26. Hardman, W.E., et al., Three percent dietary fish oil concentrate increased efficacy of doxorubicin against MDA-MB 231 breast cancer xenografts. Clin Cancer Res, 2001. 7(7): p. 2041-9.

27. Siddiqui, R.A., et al., Docosahexaenoic acid: A natural powerful adjuvant that improves efficacy for anticancer treatment with no adverse effects. Biofactors. 37(6): p. 399-412.

28. Rose, D.P. and J.M. Connolly, Effects of dietary omega-3 fatty acids on human breast cancer growth and metastases in nude mice. J Natl Cancer Inst, 1993. 85(21): p. 1743-7.

29. Maheo, K., et al., Differential sensitization of cancer cells to doxorubicin by DHA: a role for lipoperoxidation. Free Radic Biol Med, 2005. 39(6): p. 742-51.

30. Siddiqui, R.A., et al., Docosahexaenoic acid induces apoptosis in Jurkat cells by a protein phosphatase-mediated process. Biochim Biophys Acta, 2001. 1499(3): p. 265-75.

31. Rogers, K.R., et al., Docosahexaenoic acid alters epidermal growth factor receptorrelated signaling by disrupting its lipid raft association. Carcinogenesis. 31(9): p. 1523-30.

32. Corsetto, P.A., et al., Effects of n-3 PUFAs on breast cancer cells through their incorporation in plasma membrane. Lipids Health Dis. 10: p. 73.

33. Afman, L.A. and M. Muller, Human nutrigenomics of gene regulation by dietary fatty acids. Prog Lipid Res. 51(1): p. 63-70.

34. Kaur, G., et al., Docosapentaenoic acid (22:5n-3) down-regulates the expression of genes involved in fat synthesis in liver cells. Prostaglandins Leukot Essent Fatty Acids. 85(3-4): p. 155-61.

35. Chiu, L.C., E.Y. Wong, and V.E. Ooi, Docosahexaenoic acid modulates different genes in cell cycle and apoptosis to control growth of human leukemia HL-60 cells. Int J Oncol, 2004. 25(3): p. 737-44.

36. Hammamieh, R., et al., Differential effects of omega-3 and omega-6 Fatty acids on gene expression in breast cancer cells. Breast Cancer Res Treat, 2007. 101(1): p. 716.

37. Simons, K. and D. Toomre, Lipid rafts and signal transduction. Nat Rev Mol Cell Biol, 2000. 1(1): p. 31-9.

38. Menendez, J.A., L. Vellon, and R. Lupu, Targeting fatty acid synthase-driven lipid rafts: a novel strategy to overcome trastuzumab resistance in breast cancer cells. Med Hypotheses, 2005. 64(5): p. 997-1001.

39. Ravacci, G.R., et al., Lipid raft disruption by docosahexaenoic acid induces apoptosis in transformed human mammary luminal epithelial cells harboring HER-2 overexpression. J Nutr Biochem. 24(3): p. 505-15.

40. Bougnoux, P., et al., Fatty acids and breast cancer: sensitization to treatments and prevention of metastatic re-growth. Prog Lipid Res. 49(1): p. 76-86.

41. Gunstone, F.D., et al, The lipid handbook 3ed. 2007, London: Taylor \& Francis Group, LLC. 656.

42. Tvrzicka, E., et al., Fatty acids as biocompounds: their role in human metabolism, health and disease--a review. Part 1: classification, dietary sources and biological functions. Biomed Pap Med Fac Univ Palacky Olomouc Czech Repub. 155(2): p. $117-30$ 
43. Simopoulos, A.P., Omega-3 fatty acids in health and disease and in growth and development. Am J Clin Nutr, 1991. 54(3): p. 438-63.

44. Simopoulos, A.P., Evolutionary aspects of omega-3 fatty acids in the food supply. Prostaglandins Leukot Essent Fatty Acids, 1999. 60(5-6): p. 421-9.

45. Simopoulos, A.P., The importance of the omega-6/omega-3 fatty acid ratio in cardiovascular disease and other chronic diseases. Exp Biol Med (Maywood), 2008. 233(6): p. 674-88.

46. Waitzberg, D.L., R.S. Torrinhas, and T.M. Jacintho, New parenteral lipid emulsions for clinical use. JPEN J Parenter Enteral Nutr, 2006. 30(4): p. 351-67.

47. Pawlosky, R.J., et al., Physiological compartmental analysis of alpha-linolenic acid metabolism in adult humans. J Lipid Res, 2001. 42(8): p. 1257-65.

48. Edwards, I.J. and J.T. O'Flaherty, Omega-3 Fatty Acids and PPARgamma in Cancer. PPAR Res, 2008. 2008: p. 358052.

49. Parkin, D.M., Global cancer statistics in the year 2000. Lancet Oncol, 2001. 2(9): p. 533-43.

50. Parkin, D.M., F.I. Bray, and S.S. Devesa, Cancer burden in the year 2000. The global picture. Eur J Cancer, 2001. 37 Suppl 8: p. S4-66.

51. INCA, I.N.d.C., Estimativa 2012 : incidência de câncer no Brasil. 2011: Rio de Janeiro. p. 118.

52. Kaizer, L., et al., Fish consumption and breast cancer risk: an ecological study. Nutr Cancer, 1989. 12(1): p. 61-8.

53. Hursting, S.D., M. Thornquist, and M.M. Henderson, Types of dietary fat and the incidence of cancer at five sites. Prev Med, 1990. 19(3): p. 242-53.

54. Sasaki, S., M. Horacsek, and H. Kesteloot, An ecological study of the relationship between dietary fat intake and breast cancer mortality. Prev Med, 1993. 22(2): p. 187-202.

55. Terry, P.D., J.B. Terry, and T.E. Rohan, Long-chain (n-3) fatty acid intake and risk of cancers of the breast and the prostate: recent epidemiological studies, biological mechanisms, and directions for future research. J Nutr, 2004. 134(12 Suppl): p. 3412S-3420S.

56. Caygill, C.P., A. Charlett, and M.J. Hill, Fat, fish, fish oil and cancer. Br J Cancer, 1996. 74(1): p. 159-64.

57. Simonsen, N., et al., Adipose tissue omega-3 and omega-6 fatty acid content and breast cancer in the EURAMIC study. European Community Multicenter Study on Antioxidants, Myocardial Infarction, and Breast Cancer. Am J Epidemiol, 1998. 147(4): p. 342-52.

58. Simonsen, N.R., et al., Tissue stores of individual monounsaturated fatty acids and breast cancer: the EURAMIC study. European Community Multicenter Study on Antioxidants, Myocardial Infarction, and Breast Cancer. Am J Clin Nutr, 1998. 68(1): p. 134-41.

59. Rose, D.P., J.M. Connolly, and M. Coleman, Effect of omega-3 fatty acids on the progression of metastases after the surgical excision of human breast cancer cell solid tumors growing in nude mice. Clin Cancer Res, 1996. 2(10): p. 1751-6.

60. Noguchi, M., et al., Chemoprevention of DMBA-induced mammary carcinogenesis in rats by low-dose EPA and DHA. Br J Cancer, 1997. 75(3): p. 348-53.

61. Rose, D.P. and J.M. Connolly, Omega-3 fatty acids as cancer chemopreventive agents. Pharmacol Ther, 1999. 83(3): p. 217-44.

62. Bartram, H.P., et al., Effects of fish oil on rectal cell proliferation, mucosal fatty acids, and prostaglandin E2 release in healthy subjects. Gastroenterology, 1993. 105(5): p. 1317-22.

63. Hardman, W.E., Omega-3 fatty acids to augment cancer therapy. J Nutr, 2002. 132(11 Suppl): p. 3508S-3512S.

64. Bagga, D., et al., Long-chain n-3-to-n-6 polyunsaturated fatty acid ratios in breast adipose tissue from women with and without breast cancer. Nutr Cancer, 2002. 42(2): p. 180-5.

65. Wu, M., et al., Omega-3 polyunsaturated fatty acids attenuate breast cancer growth through activation of a neutral sphingomyelinase-mediated pathway. Int $\mathrm{J}$ Cancer, 2005. 117(3): p. 340-8. 
66. Harris, R.A., et al., New model of ErbB-2 over-expression in human mammary luminal epithelial cells. Int J Cancer, 1999. 80(3): p. 477-84.

67. Lewis, G.D., et al., Growth regulation of human breast and ovarian tumor cells by heregulin: Evidence for the requirement of ErbB2 as a critical component in mediating heregulin responsiveness. Cancer Res, 1996. 56(6): p. 1457-65.

68. Fernanda Cury-Boaventura, M., et al., Mechanisms involved in Jurkat cell death induced by oleic and linoleic acids. Clin Nutr, 2006. 25(6): p. 1004-14.

69. AFFYMETRIX®, P. GeneChip ${ }^{\circ}$ Gene 1.0 ST Array System for Human, Mouse and Rat. 2007 [cited; Available from: http://www.ohsu.edu/xd/research/researchcores/gmsr/about/upload/gene 10 st datasheet.pdf.

70. Lorenz, C., F. von Pelchrzim, and R. Schroeder, Genomic systematic evolution of ligands by exponential enrichment (Genomic SELEX) for the identification of proteinbinding RNAs independent of their expression levels. Nat Protoc, 2006. 1(5): p. 2204-12.

71. Irizarry, R.A., et al., Exploration, normalization, and summaries of high density oligonucleotide array probe level data. Biostatistics, 2003. 4(2): p. 249-64.

72. Tusher, V.G., R. Tibshirani, and G. Chu, Significance analysis of microarrays applied to the ionizing radiation response. Proc Natl Acad Sci U S A, 2001. 98(9): p. 511621.

73. Benjamini, Y., \& Hochberg, Y., Controlling the false discovery rate: a practical and powerful approach to multiple testing. 57. 1995: Journal of the Royal Statistical Society

74. Breitling, R., et al., Rank products: a simple, yet powerful, new method to detect differentially regulated genes in replicated microarray experiments. FEBS Lett, 2004. 573(1-3): p. 83-92.

75. Degenhardt, T., et al., Three members of the human pyruvate dehydrogenase kinase gene family are direct targets of the peroxisome proliferator-activated receptor beta/delta. J Mol Biol, 2007. 372(2): p. 341-55.

76. Mashima, T., H. Seimiya, and T. Tsuruo, De novo fatty-acid synthesis and related pathways as molecular targets for cancer therapy. Br J Cancer, 2009. 100(9): p. 1369-72.

77. Kourtidis, A., et al., An RNA interference screen identifies metabolic regulators NR1D1 and PBP as novel survival factors for breast cancer cells with the ERBB2 signature. Cancer Res. 70(5): p. 1783-92.

78. Russo, I.H. and J. Russo, Primary prevention of breast cancer by hormone-induced differentiation. Recent Results Cancer Res, 2007. 174: p. 111-30.

79. Russo, J., et al., Breast differentiation and its implication in cancer prevention. Clin Cancer Res, 2005. 11(2 Pt 2): p. 931s-6s.

80. Tobin, K.A., et al., Regulation of ADRP expression by long-chain polyunsaturated fatty acids in BeWo cells, a human placental choriocarcinoma cell line. J Lipid Res, 2006. 47(4): p. 815-23.

81. Chong, B.M., et al., Determinants of adipophilin function in milk lipid formation and secretion. Trends Endocrinol Metab. 22(6): p. 211-7.

82. Russell, T.D., et al., Cytoplasmic lipid droplet accumulation in developing mammary epithelial cells: roles of adipophilin and lipid metabolism. J Lipid Res, 2007. 48(7): p. 1463-75.

83. Abukhdeir, A.M. and B.H. Park, P21 and p27: roles in carcinogenesis and drug resistance. Expert Rev Mol Med, 2008. 10: p. e19.

84. Hyder, A., et al., Expression of fatty acid binding proteins 3 and 5 genes in rat pancreatic islets and INS-1E cells: regulation by fatty acids and glucose. Islets. 2(3): p. 174-84.

85. Piantoni, P., et al., Expression of metabolic, tissue remodeling, oxidative stress, and inflammatory pathways in mammary tissue during involution in lactating dairy cows. Bioinform Biol Insights. 4: p. 85-97.

86. Chung, S.S., et al., SUMO modification selectively regulates transcriptional activity of peroxisome-proliferator-activated receptor gamma in C2C12 myotubes. Biochem J. 433(1): p. 155-61. 
87. Wang, M., et al., Induction of mammary differentiation by mammary-derived growth inhibitor-related gene that interacts with an omega-3 fatty acid on growth inhibition of breast cancer cells. Cancer Res, 2000. 60(22): p. 6482-7.

88. Teoh, S.S., J.C. Whisstock, and P.I. Bird, Maspin (SERPINB5) is an obligate intracellular serpin. J Biol Chem. 285(14): p. 10862-9.

89. Zhang, B., et al., Effects of 5-Aza-CdR on cell proliferation of breast cancer cell line MDA-MB-435S and expression of maspin gene. J Huazhong Univ Sci Technolog Med Sci, 2007. 27(5): p. 543-6.

90. Kominsky, S.L., Claudins: emerging targets for cancer therapy. Expert Rev Mol Med, 2006. 8(18): p. 1-11.

91. Myal, Y., E. Leygue, and A.A. Blanchard, Claudin 1 in breast tumorigenesis: revelation of a possible novel "claudin high" subset of breast cancers. J Biomed Biotechnol. 2010: p. 956897.

92. Hallberg, G., et al., The expression of syndecan-1, syndecan-4 and decorin in healthy human breast tissue during the menstrual cycle. Reprod Biol Endocrinol. 8: p. 35.

93. Hozumi, K., et al., Syndecan-and integrin-binding peptides synergistically accelerate cell adhesion. FEBS Lett. 584(15): p. 3381-5.

94. Edwards, I.J., et al., In vivo and in vitro regulation of syndecan 1 in prostate cells by n-3 polyunsaturated fatty acids. J Biol Chem, 2008. 283(26): p. 18441-9.

95. Tunstall, R.J. and D. Cameron-Smith, Effect of elevated lipid concentrations on human skeletal muscle gene expression. Metabolism, 2005. 54(7): p. 952-9.

96. Deckelbaum, R.J., T.S. Worgall, and T. Seo, $n-3$ fatty acids and gene expression. Am J Clin Nutr, 2006. 83(6 Suppl): p. 1520S-1525S.

97. Tsintzas, K., et al., Elevated free fatty acids attenuate the insulin-induced suppression of PDK4 gene expression in human skeletal muscle: potential role of intramuscular long-chain acyl-coenzyme A. J Clin Endocrinol Metab, 2007. 92(10): p. 3967-72.

98. Hato, T., M. Tabata, and Y. Oike, The role of angiopoietin-like proteins in angiogenesis and metabolism. Trends Cardiovasc Med, 2008. 18(1): p. 6-14.

99. Djordjevic, S., et al., Identification of the catalytic base in long chain acyl-CoA dehydrogenase. Biochemistry, 1994. 33(14): p. 4258-64.

100. He, M., et al., Identification and characterization of new long chain acyl-CoA dehydrogenases. Mol Genet Metab. 102(4): p. 418-29.

101. Kabuyama, Y., et al., Dysregulation of very long chain acyl-CoA dehydrogenase coupled with lipid peroxidation. Am J Physiol Cell Physiol. 298(1): p. C107-13.

102. Tachibana, K., et al., Regulation of the human SLC25A20 expression by peroxisome proliferator-activated receptor alpha in human hepatoblastoma cells. Biochem Biophys Res Commun, 2009. 389(3): p. 501-5.

103. Markova, I., et al., Selected immunohistochemical prognostic factors in endometrial cancer. Int J Gynecol Cancer. 20(4): p. 576-82.

104. Zhou, D., et al., Evaluation of protein pigment epithelium-derived factor (PEDF) and microvessel density (MVD) as prognostic indicators in breast cancer. J Cancer Res Clin Oncol. 136(11): p. 1719-27.

105. Beckers, J., et al., Identification and validation of novel ERBB2 (HER2, NEU) targets including genes involved in angiogenesis. Int J Cancer, 2005. 114(4): p. 590-7.

106. DiSilvestro, R.A., et al., Soy isoflavone supplementation elevates erythrocyte superoxide dismutase, but not plasma ceruloplasmin in postmenopausal breast cancer survivors. Breast Cancer Res Treat, 2005. 89(3): p. 251-5.

107. Ozyilkan, O., E. Baltali, and S. Kirazli, CA 15-3, ceruloplasmin and tissue polypeptide specific antigen as a tumour marker panel in breast cancer. East Afr Med J, 2000. 77(6): p. 291-4.

108. Chi, H., Sphingosine-1-phosphate and immune regulation: trafficking and beyond. Trends Pharmacol Sci. 32(1): p. 16-24.

109. Watters, R.J., et al., Targeting Sphingosine-1-Phosphate Receptors in Cancer. Anticancer Agents Med Chem.

110. Snoussi, K., et al., Combined effects of IL-8 and CXCR2 gene polymorphisms on breast cancer susceptibility and aggressiveness. BMC Cancer. 10: p. 283. 
111. Yang, G., et al., CXCR2 promotes ovarian cancer growth through dysregulated cell cycle, diminished apoptosis, and enhanced angiogenesis. Clin Cancer Res. 16(15): p. 3875-86.

112. Bieche, I., et al., CXC chemokines located in the $4 q 21$ region are up-regulated in breast cancer. Endocr Relat Cancer, 2007. 14(4): p. 1039-52.

113. Borgstrom, P., R. Discipio, and T.E. Maione, Recombinant platelet factor 4, an angiogenic marker for human breast carcinoma. Anticancer Res, 1998. 18(6A): p. 4035-41.

114. Ruan, Y., W. Pei, and M. Wan, Membrane protein analysis of human breast cancer cell line MCF-7 by different membrane washing methods. Cell Biochem Funct, 2008. 26(7): p. 787-96.

115. Stepulak, A., et al., Expression of glutamate receptor subunits in human cancers. Histochem Cell Biol, 2009. 132(4): p. 435-45.

116. Sheriff, S., et al., Neuropeptide Y Y5 receptor promotes cell growth through extracellular signal-regulated kinase signaling and cyclic AMP inhibition in a human breast cancer cell line. Mol Cancer Res. 8(4): p. 604-14.

117. Lenkinski, R.E., et al., An illustration of the potential for mapping MRI/MRS parameters with genetic over-expression profiles in human prostate cancer. MAGMA, 2008. 21(6): p. 411-21.

118. Epel, M., et al., Targeting TARP, a novel breast and prostate tumor-associated antigen, with $T$ cell receptor-like human recombinant antibodies. Eur J Immunol, 2008. 38(6): p. 1706-20.

119. Oh, S., et al., Human CTLs to wild-type and enhanced epitopes of a novel prostate and breast tumor-associated protein, TARP, lyse human breast cancer cells. Cancer Res, 2004. 64(7): p. 2610-8.

120. Simpson, D.S., et al., Retinoblastoma family proteins have distinct functions in pulmonary epithelial cells in vivo critical for suppressing cell growth and tumorigenesis. Cancer Res, 2009. 69(22): p. 8733-41.

121. Gonzales, A.J. and D.W. Fry, G1 cell cycle arrest due to the inhibition of erbB family receptor tyrosine kinases does not require the retinoblastoma protein. Exp Cell Res, 2005. 303(1): p. 56-67.

122. Li, Y., et al., In vitro invasiveness of human breast cancer cells is promoted by low density lipoprotein receptor-related protein. Invasion Metastasis, 1998. 18(5-6): p. 240-51.

123. Horvat, S., J. McWhir, and D. Rozman, Defects in cholesterol synthesis genes in mouse and in humans: lessons for drug development and safer treatments. Drug Metab Rev. 43(1): p. 69-90.

124. Lee, J.N., et al., Unsaturated fatty acids inhibit proteasomal degradation of Insig-1 at a postubiquitination step. J Biol Chem, 2008. 283(48): p. 33772-83.

125. Konig, B., et al., Activation of PPARa and PPARgamma reduces triacylglycerol synthesis in rat hepatoma cells by reduction of nuclear SREBP-1. Eur J Pharmacol, 2009.

126. Moncur, J.T., et al., The "Spot 14" gene resides on the telomeric end of the 11q13 amplicon and is expressed in lipogenic breast cancers: implications for control of tumor metabolism. Proc Natl Acad Sci U S A, 1998. 95(12): p. 6989-94.

127. Kinlaw, W.B., et al., Spot 14: A marker of aggressive breast cancer and a potential therapeutic target. Endocrinology, 2006. 147(9): p. 4048-55.

128. Jump, D.B., et al., Polyunsaturated fatty acids inhibit S14 gene transcription in rat liver and cultured hepatocytes. Proc Natl Acad Sci U S A, 1993. 90(18): p. 8454-8.

129. Jump, D.B., et al., Coordinate regulation of glycolytic and lipogenic gene expression by polyunsaturated fatty acids. J Lipid Res, 1994. 35(6): p. 1076-84.

130. Scaglia, N., J.W. Chisholm, and R.A. Igal, Inhibition of stearoy/CoA desaturase-1 inactivates acetyl-CoA carboxylase and impairs proliferation in cancer cells: role of AMPK. PLoS One, 2009. 4(8): p. e6812.

131. Luyimbazi, D., et al., Rapamycin regulates stearoyl CoA desaturase 1 expression in breast cancer. Mol Cancer Ther. 9(10): p. 2770-84.

132. Morris, A., et al., Induction of anti-mammary cancer immunity by engaging the OX40 receptor in vivo. Breast Cancer Res Treat, 2001. 67(1): p. 71-80. 
133. Xie, F., et al., Costimulatory molecule OX40/OX4OL expression in ductal carcinoma in situ and invasive ductal carcinoma of breast: an immunohistochemistry-based pilot study. Pathol Res Pract. 206(11): p. 735-9.

134. Ahn, J., et al., Effects of glutathione S-transferase A1 (GSTA1) genotype and potential modifiers on breast cancer risk. Carcinogenesis, 2006. 27(9): p. 1876-82.

135. Maula, S.M., et al., Carbohydrates located on the top of the "cap" contribute to the adhesive and enzymatic functions of vascular adhesion protein-1. Eur $\mathrm{J}$ Immunol, 2005. 35(9): p. 2718-27. 

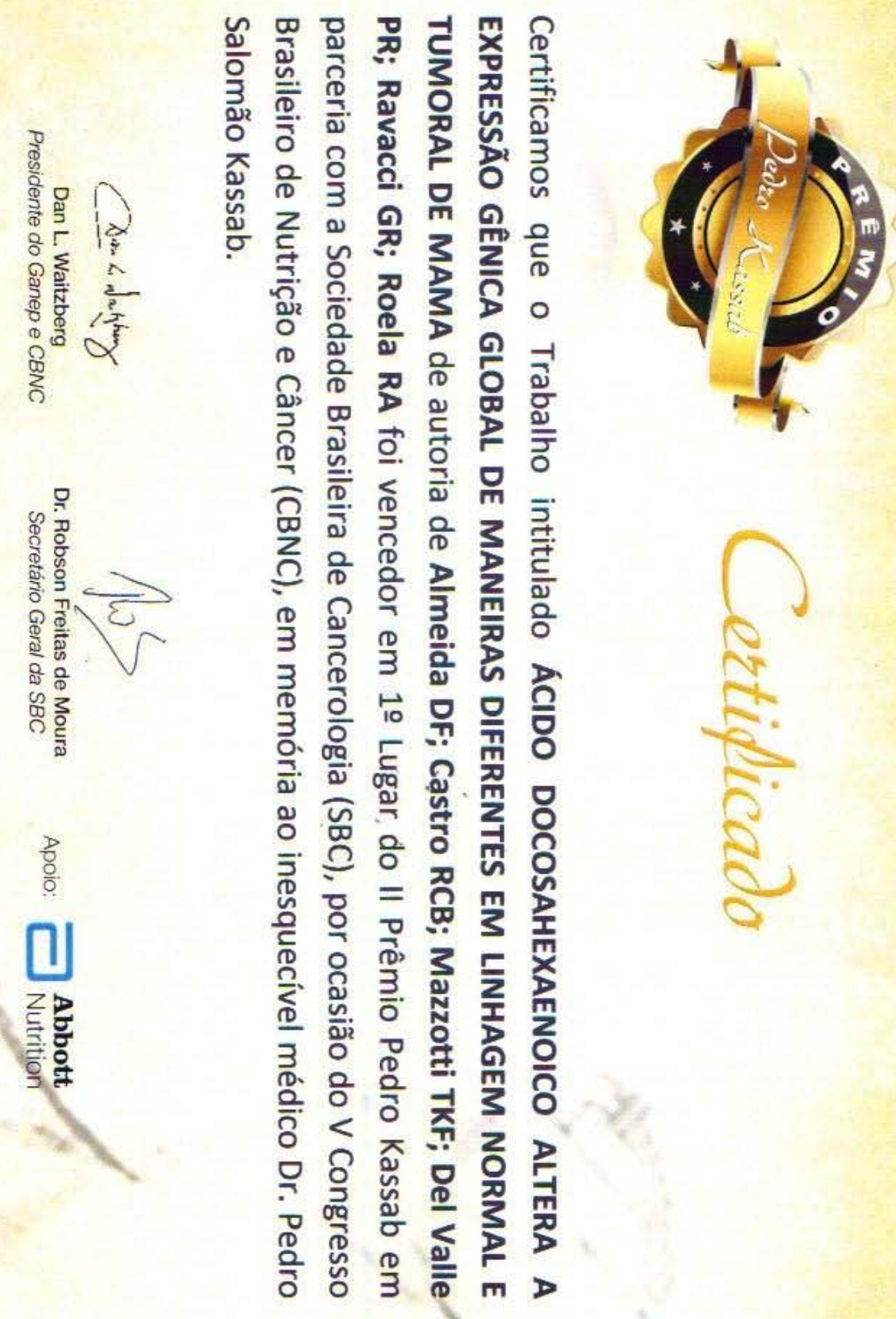

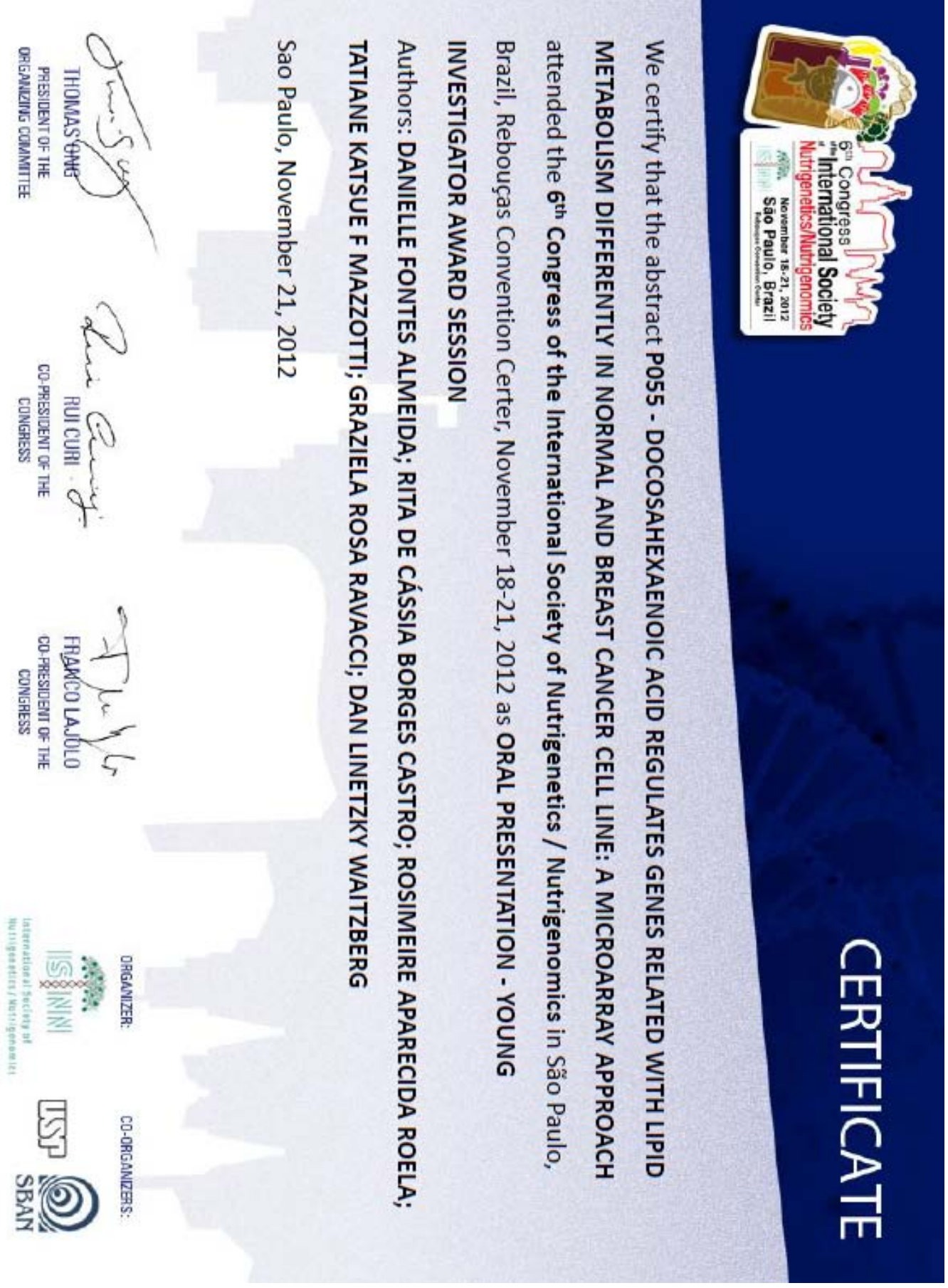